PNL-4659

UC-41 \& UC-11

\title{
Ground-Water Surveillance at The Hanford Site for CY 1982
}

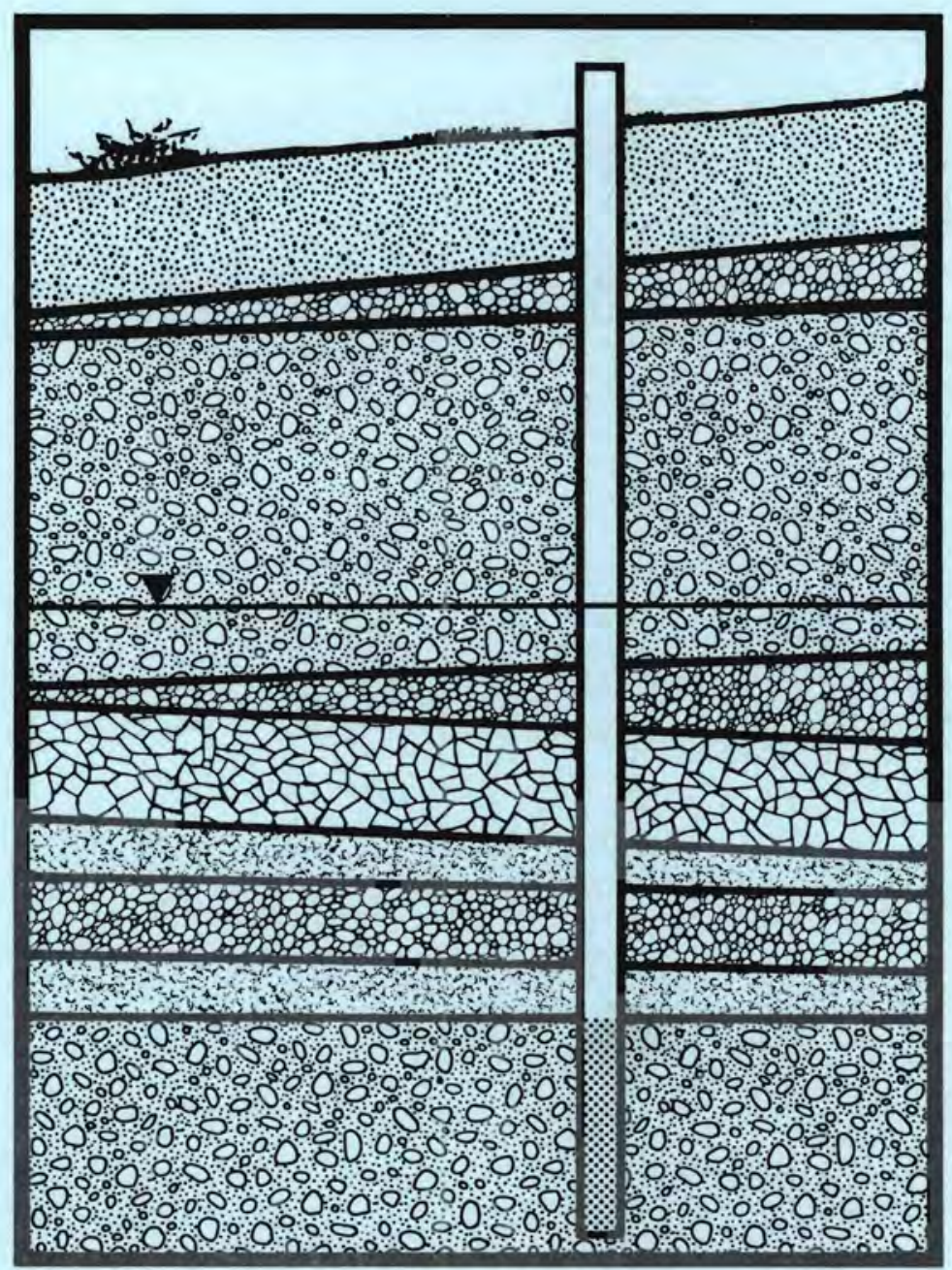

Prepared for the U.S. Department of Energy under Contract DE-AC06-76 RLO 1830

Pacific Northwest Laboratory

Operated for the U.S. Department of Energy

by Battelle Memorial Institute 


\title{
DISCLAIMER
}

This report was prepared as an account of work sponsored by an agency of the United States Government. Neither the United States Government nor any agency thereof, nor any of their employees, makes any warranty, express or implied, or assumes any legal liability or responsibility for the accuracy, completeness, or usefulness of any information, apparatus, product, or process disclosed, or represents that its use would not infringe privately owned rights. Reference herein to any specific commercial product, process, or service by trade name, trademark, manufacturer, or otherwise, does not necessarily constitute or imply its endorsement, recommendation, or favoring by the United States Government or any agency thereof. The views and opinions of authors expressed herein do not necessarily state or reflect those of the United States Government or any agency thereof.

\author{
PACIFIC NORTHWEST LABORATORY \\ operated by \\ BATTELLE \\ for the \\ UNITED STATES DEPARTMENT OF ENERGY \\ under Contract DE-AC06-76RLO 1830
}

\begin{tabular}{|c|c|}
\hline \multirow{2}{*}{\multicolumn{2}{|c|}{ Printed in the United States of America }} \\
\hline & \\
\hline \multicolumn{2}{|c|}{$\begin{array}{l}\text { Available from } \\
\text { National Technical Information Service }\end{array}$} \\
\hline \multicolumn{2}{|c|}{$\begin{array}{l}\text { National Technical Information Service } \\
\text { United States Department of Commerce }\end{array}$} \\
\hline \multirow{2}{*}{\multicolumn{2}{|c|}{$\begin{array}{l}5285 \text { Port Royal Road } \\
\text { Springfield, Virginia } 22161\end{array}$}} \\
\hline & \\
\hline \multirow{2}{*}{\multicolumn{2}{|c|}{$\begin{array}{l}\text { NTIS Price Codes } \\
\text { Microfiche A01 }\end{array}$}} \\
\hline & \\
\hline \multicolumn{2}{|c|}{ Printed Copy } \\
\hline & Price \\
\hline Pages & Codes \\
\hline $001-025$ & A02 \\
\hline $026-050$ & $\mathrm{~A} 03$ \\
\hline 051-075 & A04 \\
\hline 076-100 & A05 \\
\hline $101-125$ & A06 \\
\hline $126-150$ & A07 \\
\hline $151-175$ & $\mathrm{~A} 08$ \\
\hline $176-200$ & A09 \\
\hline $201-225$ & A010 \\
\hline $226-250$ & A011 \\
\hline $251-275$ & A012 \\
\hline $276-300$ & A013 \\
\hline
\end{tabular}


PNL-4659

UC-41 \& UC-11

\title{
Ground-Water Surveillance at The Hanford Site for CY 1982
}

\author{
P.A. Eddy \\ L.S. Prater \\ J.T. Rieger \\ June 1983 \\ Prepared for \\ the U.S. Department of Energy \\ under Contract DE-AC06-76RLO 1830
}




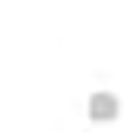

0

.

e

6

b

D 


\section{ACKNOWLEDGEMENTS}

The authors wish to acknowledge the individuals who contributed to the Ground-Water Surveillance Program in 1982 and also those who helped prepare this report.

Technical contributions to the program were made by S.C. Blair, C.S. Cline, C.R. Cole, D.W. Damschen, D. Gibson, P.J. Gutknecht, E.L. Hilty, V.L. McGhan, G.M. Petrie, A.E. Reisenauer, and D.A. Zimmerman.

The ground-water samples were collected by S. R. Bivins, K. Byrne, J. D. Harrison, D. L. Merrill, and W. W. King, under the direction of M. R. Quarders. The samples were analyzed by L. J. Kirby and F. P. Brauer.

Data management was performed by P. J. Blumer and L. E. Bisping.

Typing and secretarial support was provided by G. L. Dirkes and S. C. Canada. M. A. McKinney, S. Chadez-Hartley, the typesetting team, and the 300 Area word processing team (especially C. M. Gilbert) aided in the preparation of this report.

The authors also appreciate the assistance and the many valuable suggestions provided by M. J. Sula, W. D. McCormack, and other staff members of the Hanford Environmental Surveillance Program. 
8

E

,

e

$Q$ 


\section{SUMMARY}

Operations at the Hanford Site since 1944 have resulted in the discharge of large volumes of process cooling water and other waste waters to the ground. These effluents, which have reached the unconfined ground water, contain low levels of radioactive and chemical substances. The movement of these constituents in the unconfined ground water is monitored as part of the Ground-Water Surveillance Program.

During 1982, 324 monitoring wells were sampled at various times for radioactive and chemical constituents. Two of these constituents, tritium and nitrate, are readily transported in ground water; therefore, these substances are the primary ones used to monitor the movement of the ground water. This report, which is one of a series prepared annually to document and evaluate the status of the ground water at the Hanford Site, describes recent changes in the configuration of the tritium and nitrate plumes. The plumes change with time in response to groundwater flow, ionic dispersion, and radioactive decay.
The tritium plume continues to show increasing concentrations near the Columbia River. While it is mapped as having reached the Columbia River, its contribution to the river has not been distinguished from other sources at this time. The general plume configuration is much the same as in 1978, 1979, 1980, and 1981.

The size of the nitrate plume appears stable. Concentrations of nitrate in the vicinity of the 100-H Area continue to be high as a result of past leaks from an evaporation facility.

In addition to describing the present status of the ground water beneath the Hanford Site, this report describes the results of studies conducted in support of the ground-water surveillance effort during CY 1982. These studies provided data that will help to better characterize the ground-water system, refine the hydrologic and transport models, and determine the impact of Site operations on the environment. 
0

a

$\therefore$

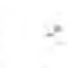




\section{CONTENTS}

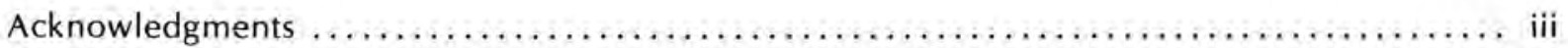

Summary $, \ldots, \ldots, \ldots, \ldots, \ldots, \ldots, \ldots, \ldots, \ldots, \ldots, \ldots, \ldots, \ldots, \ldots, \ldots \ldots \ldots, \ldots, v$

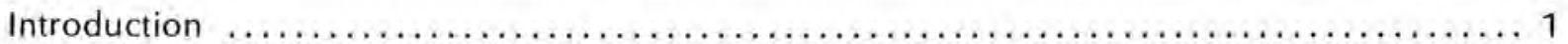

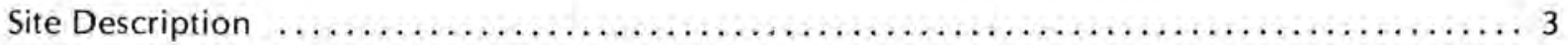

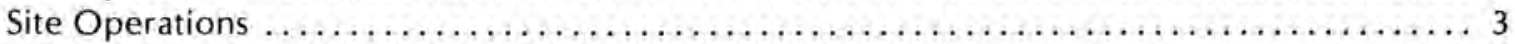

Geology and Hydrology of the Site $\ldots, \ldots, \ldots, \ldots, \ldots, \ldots, \ldots, \ldots, \ldots, \ldots, \ldots, \ldots, 4$

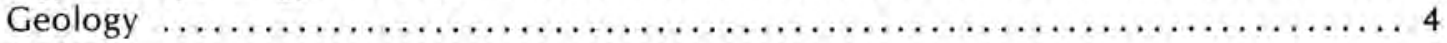

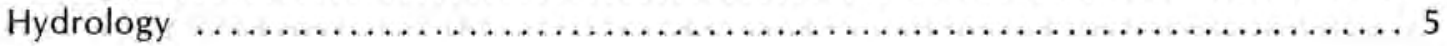

Methods $\ldots \ldots \ldots, \ldots, \ldots, \ldots, \ldots, \ldots, \ldots, \ldots, \ldots, \ldots, \ldots, \ldots, \ldots, \ldots, \ldots, \ldots, 7$

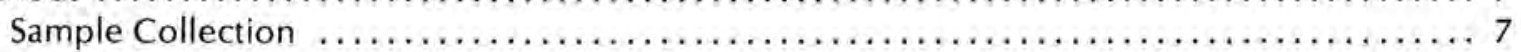

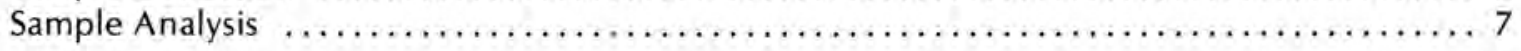

Distribution and Concentration of Radionuclides and Chemicals in the Ground Water ....... 11

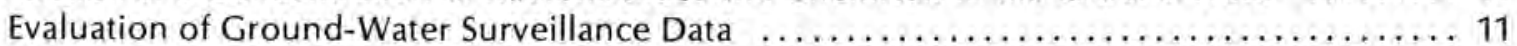

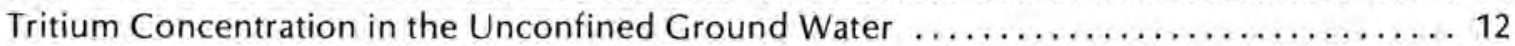

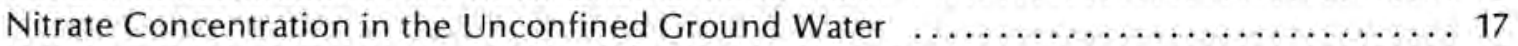

Gross Beta Concentration in the Unconfined Ground Water $\ldots \ldots \ldots \ldots \ldots \ldots \ldots \ldots \ldots 21$

Radiological Impact $\ldots \ldots \ldots \ldots \ldots \ldots \ldots \ldots \ldots \ldots \ldots \ldots \ldots \ldots \ldots \ldots \ldots \ldots \ldots \ldots \ldots \ldots \ldots \ldots \ldots \ldots \ldots \ldots, 23$

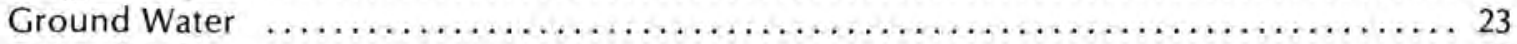

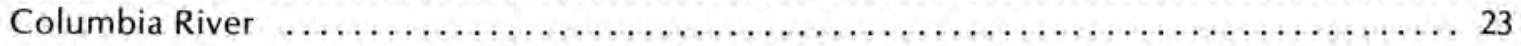

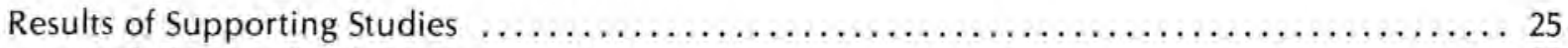

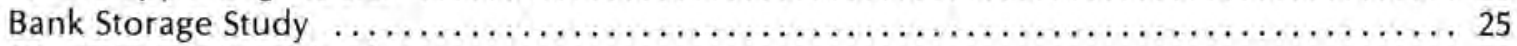

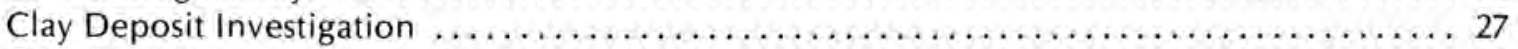

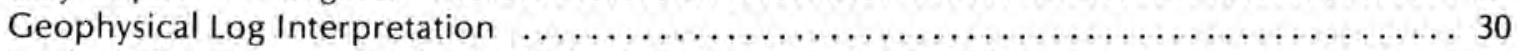

Update of Input Data for the Variable Thickness Transient Model $\ldots \ldots \ldots \ldots \ldots \ldots \ldots \ldots \ldots 1$

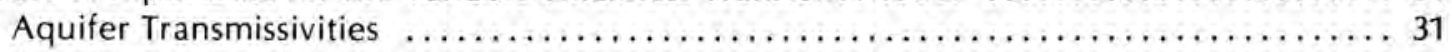

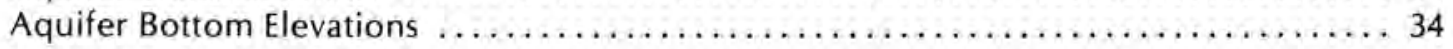

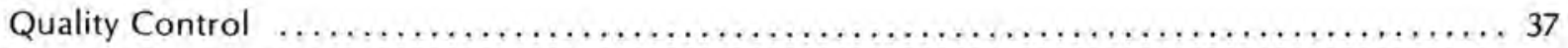

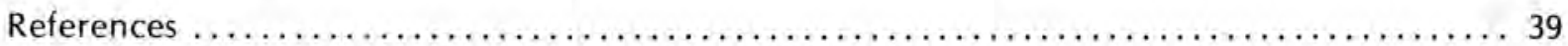

Appendix A: Tritium and Nitrate Concentrations in the Ground Water

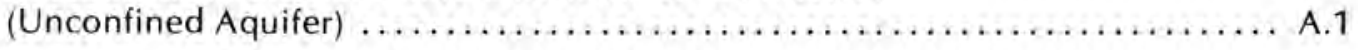

Appendix B: Gross Alpha, Strontium-90, Cesium-137, Cobalt-60, Uranium,

Ruthenium-106, Chromium, and Fluoride Concentrations in the

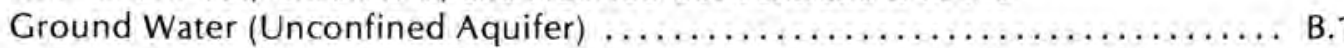

Appendix C: Chemical and Spectrographic Analyses from Various

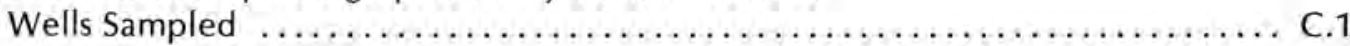




\section{FIGURES}

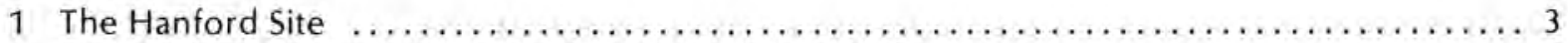

2 Generalized Geologic Cross Section of the Hanford Site $\ldots \ldots \ldots \ldots \ldots \ldots \ldots \ldots \ldots, \ldots, 4$

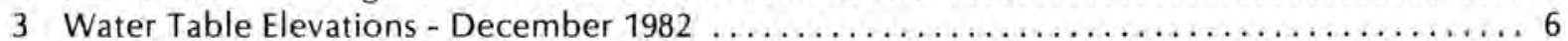

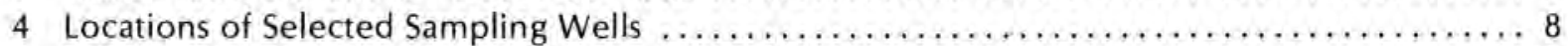

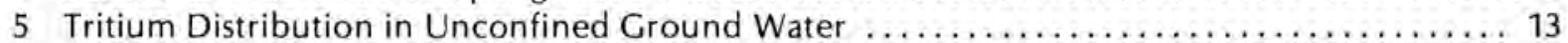

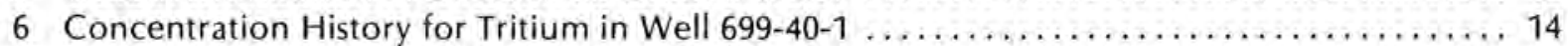

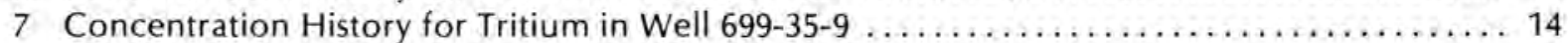

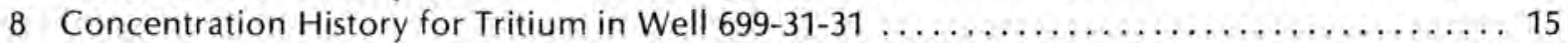

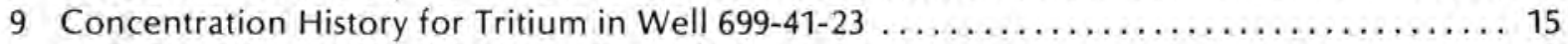

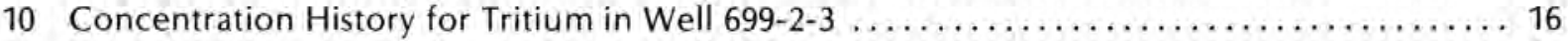

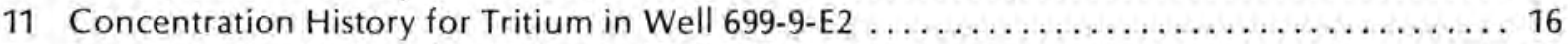

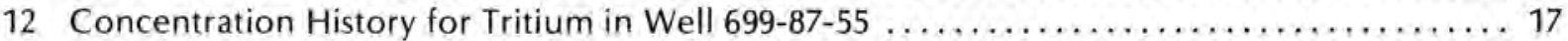

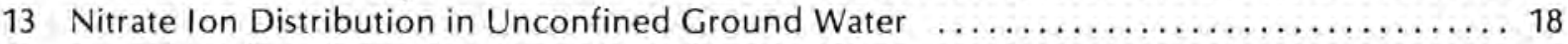

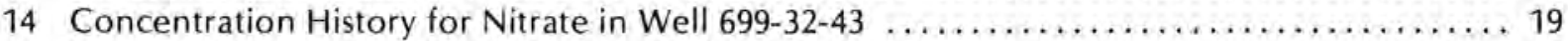

15 Concentration History for Nitrate in Well $699-32-22 \ldots \ldots \ldots \ldots \ldots \ldots \ldots \ldots \ldots \ldots \ldots \ldots \ldots$

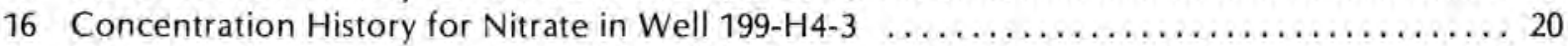

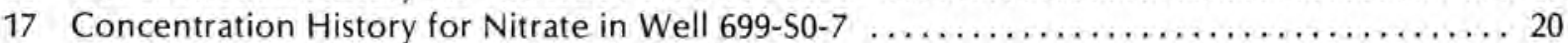

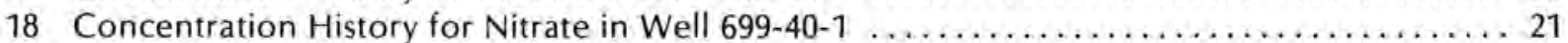

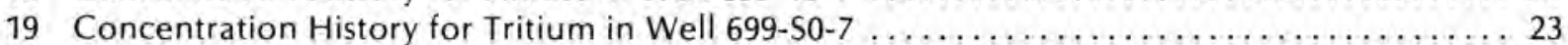

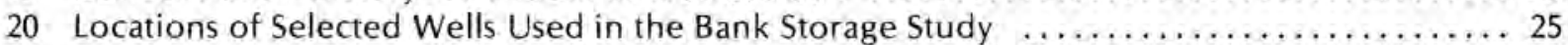

21 Changes in the Water Level in Well 699-48-7 Compared with Changes in the

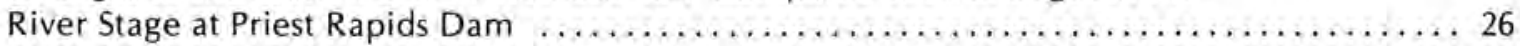

22 A Comparison of Changes in the Water Levels in Wells 699-43-3, 699-45-4,

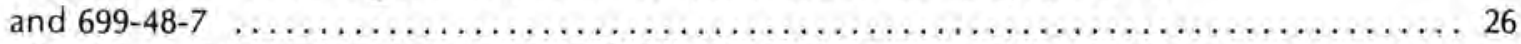

23 Changes in Tritium Concentrations in Well 699-47-6 Compared with Changes

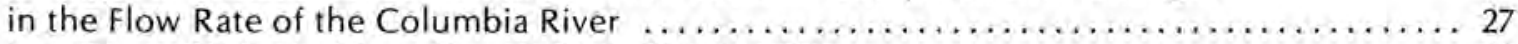

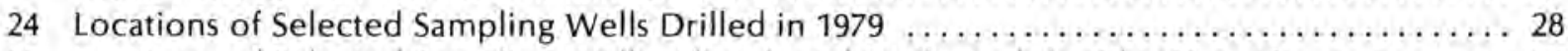

25. Locations of Selected Sampling Wells, Abandoned Wells, and the Clay Deposit .......... 29

26 Changes in the Water Level in Well 699-39-1 Compared with Changes

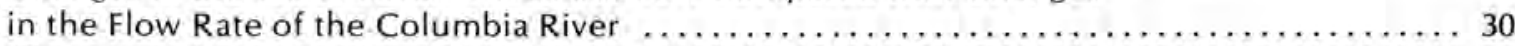

27 Changes in the Water Level in Well 699-45-4 Compared with Changes

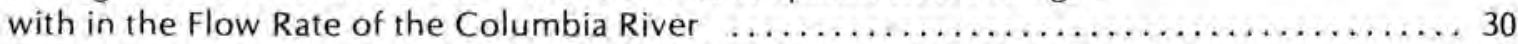

28 Changes in Tritium Concentrations in Wells 699-47-6 and 699-41-1 Compared with Changes in the Flow Rate of the Columbia River $\ldots \ldots \ldots, \ldots \ldots \ldots \ldots \ldots \ldots, 31$

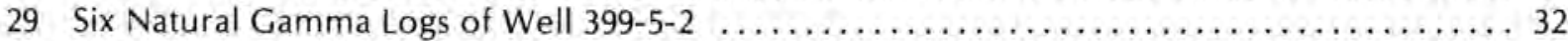

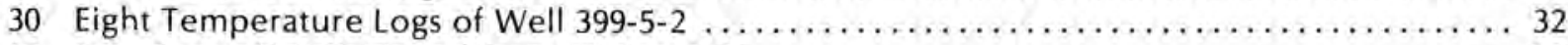

31 Locations of Wells Tested from 1973 to $1981 \ldots \ldots \ldots \ldots \ldots \ldots \ldots \ldots \ldots \ldots \ldots \ldots \ldots \ldots, \ldots \ldots \ldots$

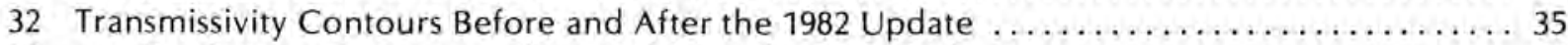

33 Aquifer Bottom Contours Before and After the 1980 Update ..................... 36

\section{TABLES}

1 Minimum Detectable Concentrations and Lowest Applicable Concentration Guides or Drinking Water Standards for Various Radionuclides and Chemicals . . . . . . . 11

2 Numerical Data on the Routine Ground-Water Monitoring Program, $1982 \ldots \ldots \ldots \ldots \ldots 12$ 


\section{INTRODUCTION}

Ground-water surveillance at the Hanford Site is a facet of the Hanford Environmental Surveillance Program, which is conducted by the Pacific Northwest Laboratory (PNL) for the U.S. Department of Energy (DOE). This comprehensive program is designed to evaluate existing and potential pathways of exposure to radioactivity from Site operations. The objectives of the ground-water surveillance portion of this program are as follows: 1) measure and report the concentration and distribution of radioactive and other chemical constituents in the ground water, 2) determine the movement and transport of constituents with time, and 3) evaluate the impact of ground-water contamination on people and their environment.

To achieve these objectives, the Ground-Water Surveillance Program collects and analyzes ground-water samples and then interprets the results. The program also performs technical studies that provide additional information on the ground-water system and on the behavior of constituents within the system.
Each year, data collected by the Ground-Water Surveillance Program are evaluated, summarized, and published in an annual report. This document contains an evaluation of data collected during calendar year 1982. Data from past years are contained in reports similar to this one.

The primary purposes of this report are to describe the concentration and distribution of various constituents in the ground water and to assess their potential impact. In addition, the report describes the results of technical studies conducted in 1982.

Additional information on environmental surveillance at the Hanford Site may be found in two other reports issued annually. The most recent titles are:

- Environmental Surveillance at Hanford for CY 1982 by Sula et al. (PNL-4657) and;

- Environmental Status of the Hanford Site for CY 1981 by Sula, Blumer, and Dirkes (PNL-4212). 


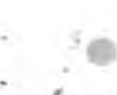

*

.

e

4 


\section{SITE DESCRIPTION}

The Hanford Site, which is operated by DOE, is located in southeastern Washington. The Site, shown in Figure 1 , occupies $1,476 \mathrm{~km}^{2}\left(570 \mathrm{mi}^{2}\right)$ of the semiarid Pasco Basin, which is a large structural and topographic basin. The Site receives approximately $16 \mathrm{~cm}$ (6.3 in.) of precipitation annually, of which about $40 \%$ occurs during the winter months. The desert plains on which the Site is situated rise gradually from an altitude of about 400 feet above mean sea level in the southeastern part of the Site to about 700 feet in the northwestern part (Newcomb, Strand, and Frank 1972). In places along the boundaries and in the center of the Site, bedrock anticlines or ridges rise above the plains. The Columbia River flows through the northern part of the Site and forms part of its eastern boundary. The Yakima Ridges, Rattlesnake Mountain, and the Yakima River form the west and south boundaries of the Site. The cities of Richland, Pasco, and Kennewick, known as the Tri-Cities, are situated on the Columbia River downstream of the Site and have a combined population of about 90,000 .

\section{SITE OPERATIONS}

The Hanford Site was established in 1943 under the Manhattan Project to produce plutonium for nuclear weapons. At one time, nine production reactors were in operation at the Site, but only one of these (N Reactor) is currently operating. $N$ Reactor is a dual purpose reactor, producing both plutonium and steam for power production. Another reactor, called the Fast Flux Test Facility (FFTF), has been built onsite and is used for research. At present, the main activities at the Site include reactor operation, fuel fabrication, waste management, and energy-related research and development.

Site operations have resulted in the production of large volumes of waste water. Some of these effluents, including process cooling water and water containing low-level radioactive wastes, have been discharged to the ground. Subsurface structures such as cribs have been used for disposal of the water containing low-level radioactive wastes, while surface ponds and ditches

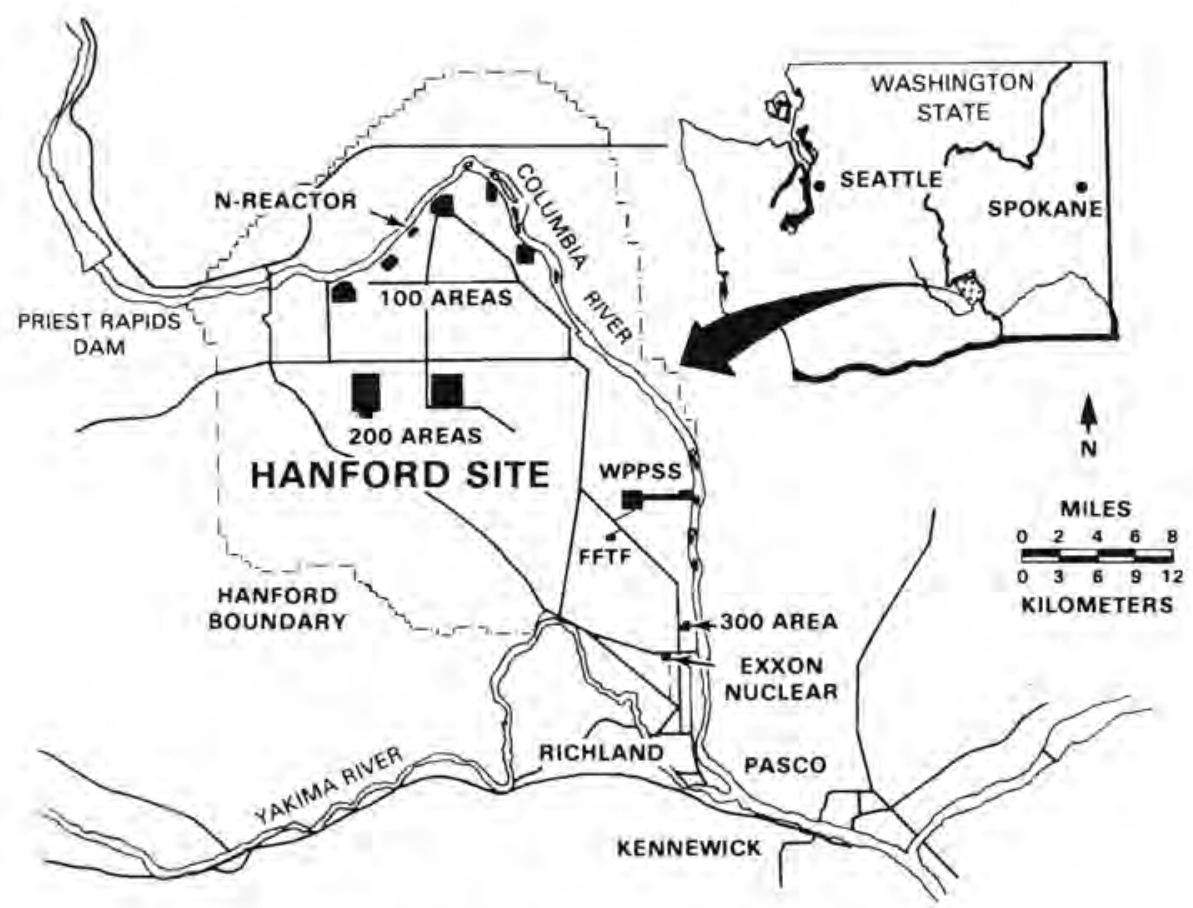

FIGURE 1. The Hanford Site 
have been used for the disposal of the cooling water (Graham et al. 1981). These disposal facilities are located at the various operating areas shown in Figure 1, including the 100 Areas, 200 Areas, and 300 Area. The majority of waste water has been released through disposal facilities at or near the chemical separations area (200 Areas), which is located on a plateau near the center of the Site. Smaller amounts of waste water have been released through disposal facilities at the reactor sites (100 Areas) and at the fuel fabrication area (300 Area).

The disposal of waste water to the ground has been greatly reduced at Hanford in the past several years, primarily because of the deactivation of all reactors except the $\mathrm{N}$ Reactor, the cessation of reactor fuel processing, and the improved treatment of several waste strearns.

\section{GEOLOGY AND HYDROLOGY OF THE SITE}

Geologic and hydrologic properties of the Site's subsurface affect the movement of the waste water that has been discharged to the ground. Therefore, brief descriptions of the geology and hydrology are given in the following sections.

\section{Geology}

The main geologic units beneath the Hanford Site include, in ascending order, the Columbia River Basalt Group, the Ringold Formation, and a series of glaciofluvial sediments. A generalized geologic cross section of the Site is shown in Figure 2.

The Columbia River Basalt Group, which is the bedrock beneath the Site, is a thick series of lava flows extruded from fissures. These basalts have

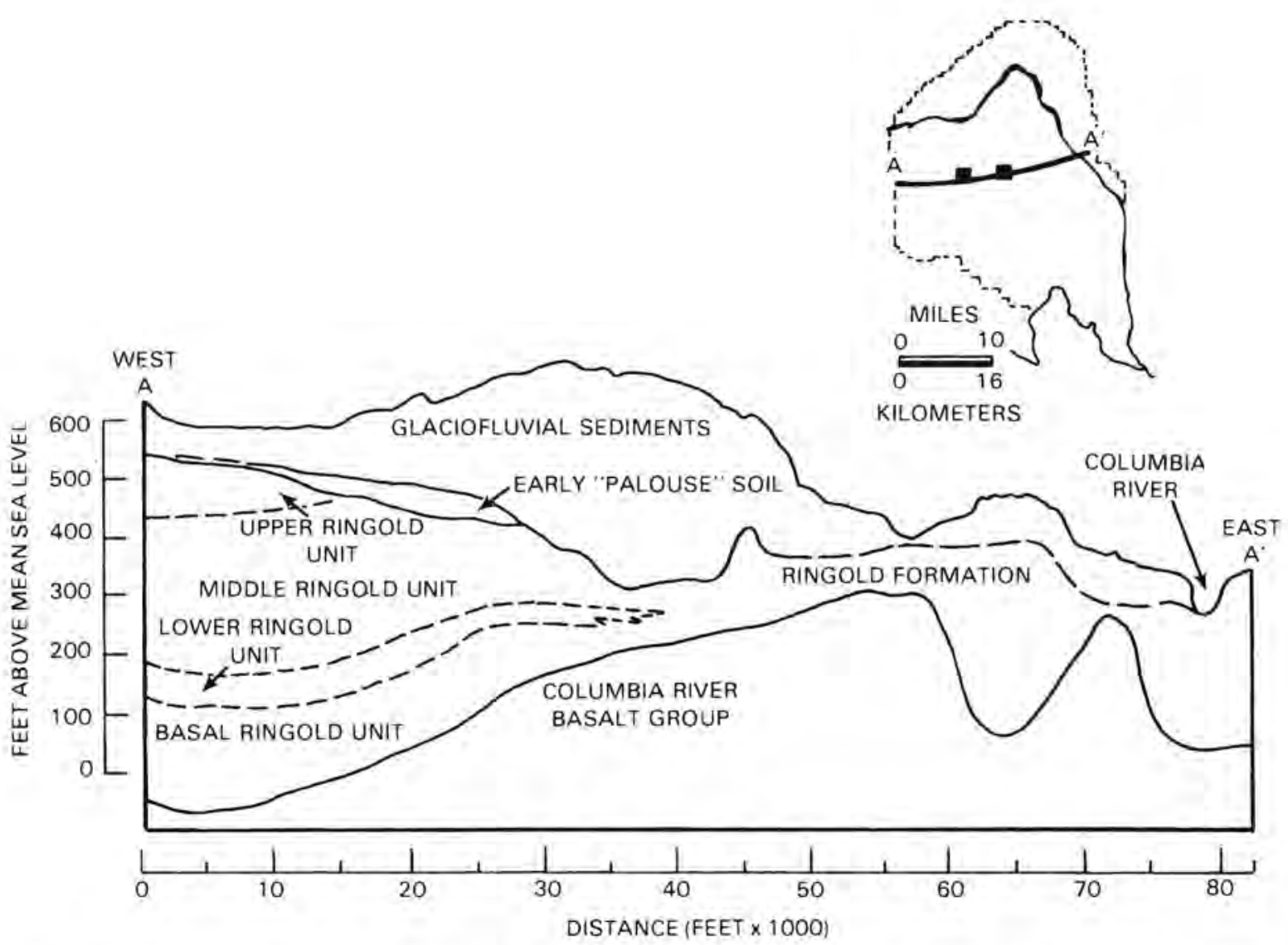

FIGURE 2. Generalized Geologic Cross Section of the Hanford Site (Modified from Tallman et al. 1979) 
been warped and folded, producing anticlines that, in some places, crop out at the land surface. The Ringold Formation overlies the basalts, except in some localized areas where it has been removed by erosion. This formation is broken down into four units, the basal, lower, middle and upper units, which consist mainly of bedded silts and sands deposited in a lacustrine environment. Beneath the 200 West Area, sediments of the upper Ringold Formation have been reworked by the wind and redeposited as a silt layer called the Palouse soil. The glaciofluvial sediments rest atop the Ringold Formation or, in places where the Ringold has been removed, the basalts. These sediments were deposited by the ancestral Columbia River when it was swollen by glacial meltwater. The glaciofluvial sediments are composed primarily of gravels, sands, and some silts (Newcomb, Strand and Frank 1972).

\section{Hydrology}

Both confined and unconfined aquifers are present beneath the Hanford Site. The confined aquifers, in which the ground water is under pressure greater than that of the atmosphere, are found mainly within the Columbia River Basalts. The unconfined or water-table aquifer is the uppermost aquifer, and it consists primarily of the Ringold Formation and to a lesser extent the glaciofluvial sediments (Gephart et al. 1979). Of all the aquifers beneath the Site, the unconfined aquifer has been most affected by waste water disposal at Hanford; therefore, the ground-water surveillance effort is focused on this aquifer.
The unconfined aquifer reaches a thickness of over $70 \mathrm{~m}(230 \mathrm{ft})$ in some areas and pinches out along the flanks of the basalt anticlines. The bottom of the aquifer is the top of the basalt or, in some locations, the clay zones of the lower unit of the Ringold Formation (Graham et al. 1981). On the Hanford Site, the depth to the water table ranges from less than $0.3 \mathrm{~m}(1 \mathrm{ft}$ ) to over

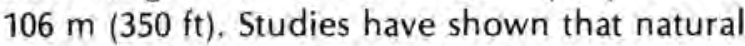
recharge through the thick unsaturated zone is negligible. However, some natural recharge does occur, principally along the base of the bordering anticlines where precipitation and runoff infiltrate to the water table (Gephart et al. 1979). In addition, the aquifer is artificially recharged by the waste and cooling water released onsite.

Changes in the water table configuration during the past 39 years are the result of disposal to the ground of more than $6 \times 10^{11}$ liters (160 billion gallons) of process cooling water and more than $3 \times 10^{10}$ liters ( 8 billion gallons) of other waste waters. Ground-water mounds created by the discharge of water now exist near each of the chemical processing and waste management facilities (figure 3). These mounds interrupt the general flow pattern in the aquifer, from the recharge areas in the west to the discharge areas (primarily the Columbia River) in the east. Ground-water levels have changed continuously over the years because of variations in the volume of waste water discharged to the ground. The movement of the ground water and its associated constituents has also changed with time and reflects the amount of effluent discharged. 


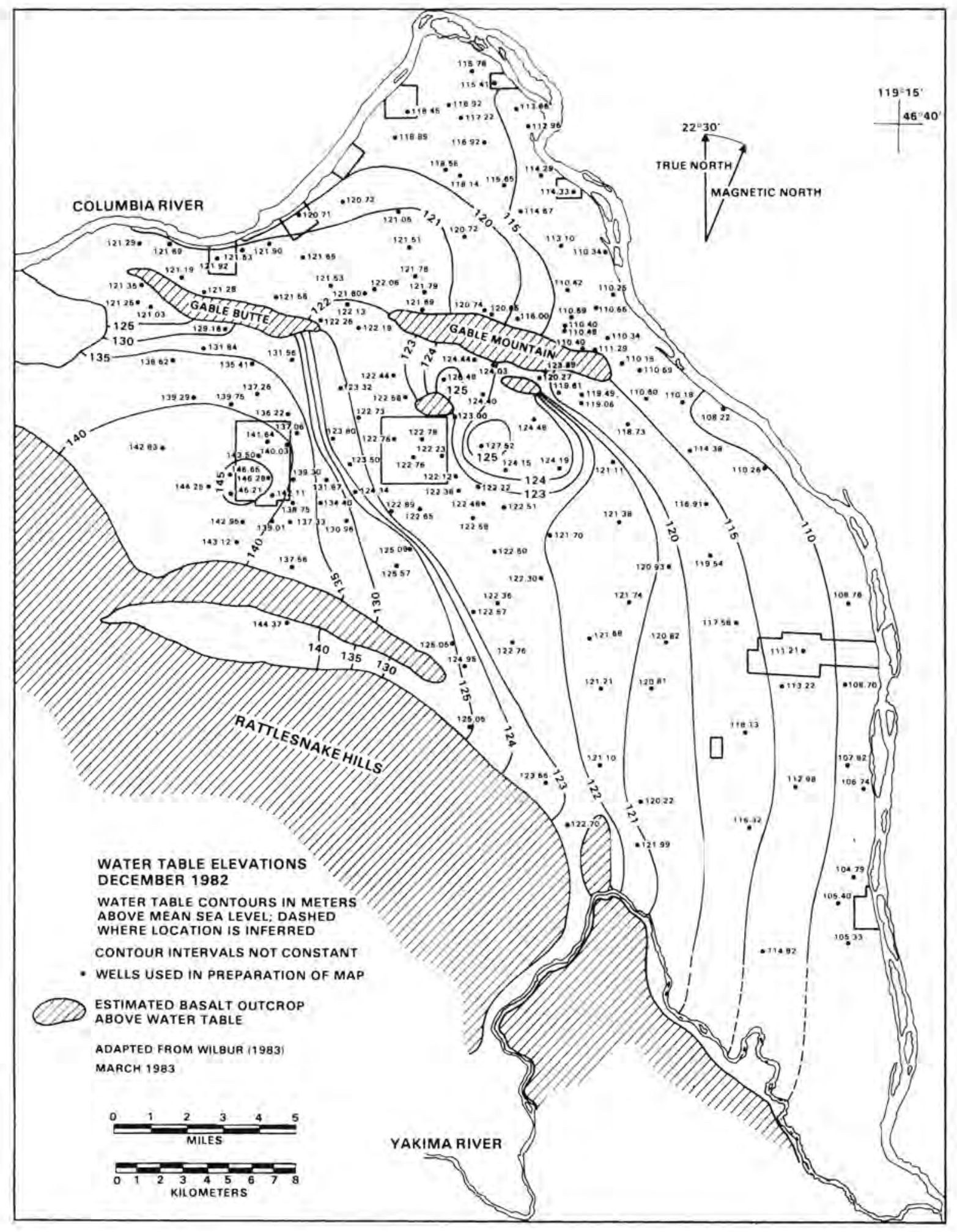

FIGURE 3. Water Table Elevations - December 1982 


\section{METHODS}

Over 2200 wells have been constructed on the Hanford Site from pre-Hanford Works days to the present. About 850 of these wells were drilled to the ground-water table, and about 780 still contain water. The others have become dry through infiltration of sediments or a general lowering of the water table in their vicinity (McGhan and Damschen 1979). These wells provide a means for obtaining ground-water samples and for conducting onsite investigations. Locations of selected sampling wells are shown in Figure 4.

Most of the wells drilled at Hanford are multipurpose structures. As the wells are drilled, geologic and hydrologic information is obtained. After drilling is completed, the wells become sampling structures. Most of the wells are six or eight inches in diameter and have steel casings. The wells are usually perforated or screened along the upper portion of the saturated zone of the aquifer.

\section{SAMPLE COLLECTION}

Ground-water samples are obtained routinely from wells throughout the Hanford Site, according to a master schedule that is formulated each year (Blumer, Sula, and Eddy 1981). All routine ground-water samples for 1982 referred to in this report were taken by the Environmental Evaluations Section of the Occupational and Environmental Protection Department of PNL. For the 1982 routine Ground-Water Surveillance Program, 324 wells were sampled. From these, 1467 well-water samples were taken to provide 3741 analytical results for evaluating the effects of Site operations on the ground water. (These figures do not include the monitoring efforts of other DOE contractors on the Hanford Site.) The frequency of sampling is monthly, quarterly, semiannually, or annually, depending on the location of the well and constituents to be analyzed. The volume of each sample is determined by the number of constituents for which that particular sample will be analyzed.

Most of the ground-water samples are collected using submersible pumps. These pumps have been installed in a majority of the regularly sampled wells. Bailers are used to sample the wells that do not have pumps. Since the submersible pumps are left in the wells, this method prevents the possibility of cross contarnination that may result from using a single bailer or pump to sample several wells.

When a bailer must be used, the sample is collected by lowering a plastic bottle enclosed in a steel bailer. The sample is collected just below the surface of the water table because this is where the greatest concentration of contaminants is usually observed (Eddy, Myers, and Raymond 1978).

Most of the samples are collected from the unconfined aquifer. However, at a few locations where appropriate wells are available, samples are obtained from the confined aquifers.

\section{SAMPLE ANALYSIS}

The ground-water samples collected in 1982 were analyzed by PNL's Technical Analysis Section and Analytical and Nuclear Research Section. In addition, the U.S. Geological Survey collected and analyzed samples from specific wells,

The ground-water samples are analyzed for a variety of radioactive and nonradioactive constituents. Most of these samples are analyzed for tritium $\left({ }^{3} \mathrm{H}\right)$ and nitrate $\left(\mathrm{NO}_{3}^{-}\right)$because these two constituents are readily transported in ground water with little decrease in concentration from adsorption or ion exchange. In addition, samples from selected wells are routinely analyzed at less frequent intervals for the radionuclides strontium-90, cesium-137, and cobalt-60. Gross alpha (as ${ }^{239} \mathrm{Pu}$ ) emission is also determined. Selected samples are analyzed by gamma spectrometry to identify the mixture of radionuclides present. Standard radiometric and chemical methods are used to analyze the routine groundwater samples (ASTM 1979).

Other radionuclides, such as iodine- 129 and technetium-99, have been detected in the ground water beneath the Hanford Site. A small number of samples are analyzed for these constituents. In addition, analyses for natural ura- 


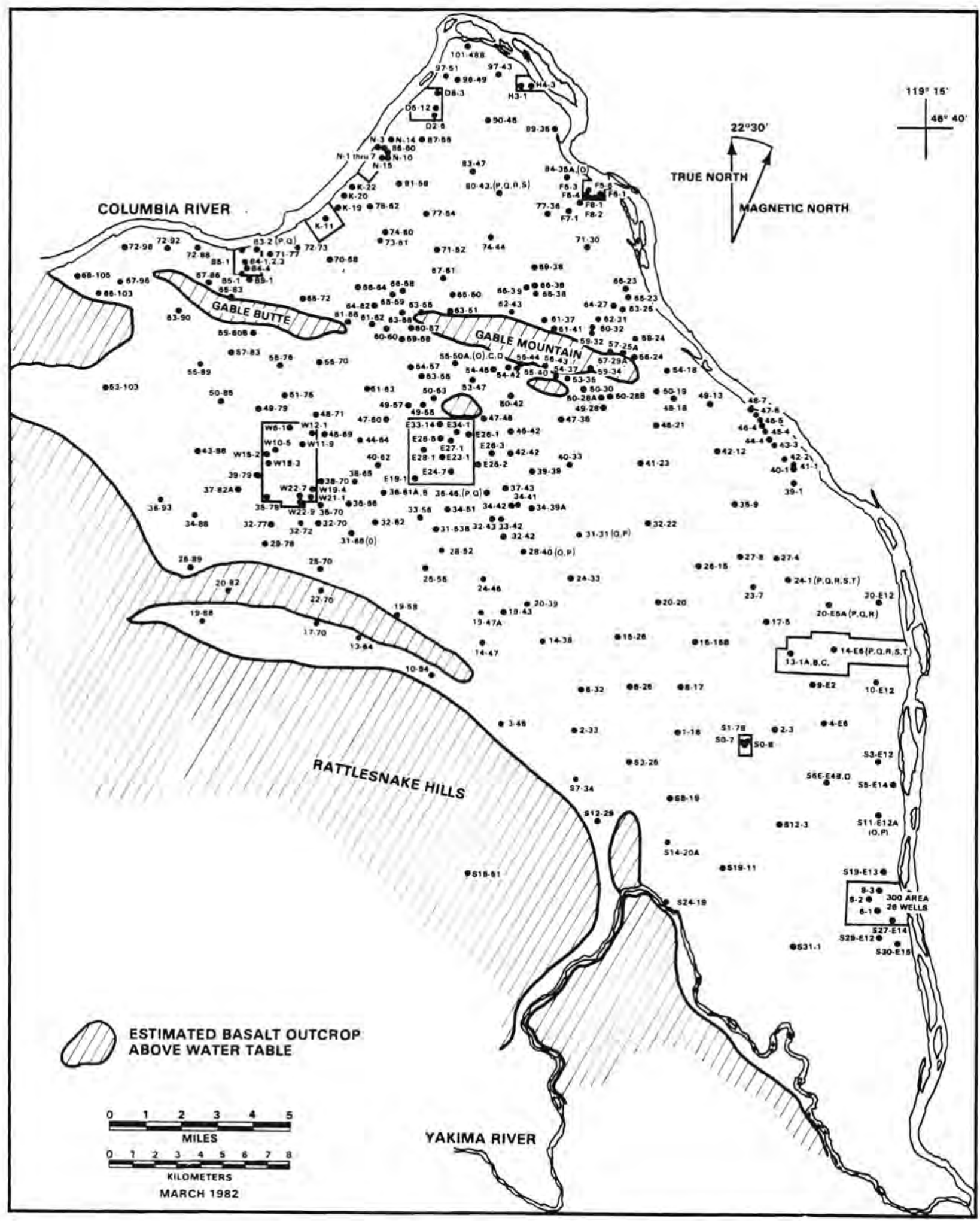

FIGURE 4. Locations of Selected Sampling Wells 
nium, fluoride $\left(\mathrm{F}^{-}\right)$, and chromium $\left(\mathrm{Cr}^{+6}\right)$ are made on selected ground-water samples collected from areas where these substances are present.
Organic chemicals are not presently included in the list of routine analyses performed on the samples. However, a few special samples have been collected and analyzed for organics. 


\section{DISTRIBUTION AND CONCENTRATION OF RADIONUCLIDES AND CHEMICALS IN THE GROUND WATER}

Liquid effluents released to the ground have percolated downward and laterally through 50 to $100 \mathrm{~m}$ ( 150 to 300 feet) of unconsolidated sediments that overlie the saturated portion of the unconfined aquifer. As the wastes have moved through these sedimentary materials, adsorption and ion exchange have taken place between the minerals in the sediments and the substances in the waste water. Some of the longer lived radionuclides, such as strontium-90, cesium-137, and plutonium-239, have good ionexchange characteristics and have been effectively held in the soil column as the waste water has percolated downward. Other radionuclides, such as tritium, iodine-129 and technetium-99, have poor ion-exchange characteristics. These radionuclides have moved through the soil column at varying rates until eventually entering the ground water. Subsequently, they have moved in a general down-gradient direction at a rate nearly equal to the velocity of the ground water. As the radionuclides have moved with the ground water, their concentrations have been further reduced by radioactive decay, ion exchange, diffusion, and hydrodynamic dispersion.

Through the years, the Ground-Water Surveillance Program has monitored the constituents in the ground water and the ground-water movement. A discussion of the present (1982) distribution and concentration of radionuclides and chemicals in the ground water is contained in this chapter.

\section{EVALUATION OF GROUND-WATER SURVEILLANCE DATA}

Radionuclide concentrations in the ground water beneath the Hanford Site are evaluated in terms of their respective Concentration Guides (CGs) (U.S. Department of Energy 1981). Radioactive materials are also compared with drinking water standards (DWS) promulgated by the Environmental Protection Agency (EPA 40 CFR 141) and adopted by the state of Washington. The comparison between the actual concentration and the CGs provides a conservative method for evaluating the potential significance of most water-borne materials. The CGs used in this report are those that apply to uncontrolled areas, even though the use of the ground water is controlled. Table 1 shows the minimum detectable concentrations (MDC) and applicable CGs or drinking water standards for primary radionuclides and various chemicals analyzed under the routine Ground-Water Surveillance Program.

This chapter includes sections describing the concentration and distribution of tritium, nitrate, and gross beta in the unconfined aquifer. Each section (except for the one on gross beta) contains a map showing the distribution of the radionuclide or chemical described in that section. The isopleths on the maps show concentration zones rather than discrete contours since the data do not justify the additional detail.

Appendix A contains tabular analytical data for 1982 on the maximum, average, and minimum

TABLE 1. Minimum Detectable Concentrations and Lowest Applicable Concentration Guides or Drinking Water Standards for Various Radionuclides and Chemicals

$\begin{array}{ccc}\mathrm{MDC}, & \mathrm{DWS}, & \mathrm{CGs}, \\ \mathrm{pCi} / \mathrm{ml} & \mathrm{pCi} / \mathrm{m \ell} \\ \mathrm{pCi} / \mathrm{ml}\end{array}$

\section{Radionuclides}

Gross Beta (as ${ }^{106} \mathrm{Ru}$ )

Total Alpha (as 239pu) ${ }^{3} \mathrm{H}$

${ }^{60} \mathrm{Co}$

${ }^{90} \mathrm{Sr}$

${ }^{106} \mathrm{Ru}$

${ }^{125} \mathrm{Sb}$

729

131

${ }^{137} \mathrm{Cs}$

$U$ (Natural)

0.08
0.017
0.5
0.02
0.03
0.06
0.06
$1 \times 10^{-8}$
0.01
0.02
$0.03(\mathrm{mg} / \mathrm{l})$

$0.05 \quad \mathrm{NA}(\mathrm{a})$

$0.015 \quad$ NA

$20 \quad 3,000.0$

NA $\quad 30.0$

$0.008 \quad 0.3$

NA $\quad 10.0$

NA $\quad 100.0$

NA $\quad 0.06$

NA $\quad 0.3$

NA $\quad 20.0$

Chemicals

$\mathrm{NO}_{3}^{-}$

$\mathrm{F}^{-}$

$\mathrm{Cr}^{+6}$

$0.5(\mathrm{mg} / \mathrm{l})$

$0.08(\mathrm{mg} / \mathrm{l})$ $0.01(\mathrm{mg} / \mathrm{l})$

$\begin{array}{cc}45(\mathrm{~b})(\mathrm{mg} / \ell) & \text { NA } \\ 1.8(\mathrm{mg} / \mathrm{l}) & \text { NA } \\ 0.05(\mathrm{mg} / \mathrm{l}) & \text { NA }\end{array}$

(a) NA - Not Applicable.

(b) Calculated as $\mathrm{NO}_{3}^{-}$ 
concentrations of tritium and nitrate. The average concentrations of these constituents were used to generate the isopleth maps. While published data from the 200 Areas were used to provide continuity in the maps (Wilbur and Graham 1982), these data were not included in Appendix A.

Table 2 shows the number of wells sampled, the number of samples taken, and the number of analyses made as part of the 1982 Ground-Water Surveillance Program for each area of the Hanford Site. The data shown in Appendices A (tritium and nitrate) and B (selected constituents in ground water) were derived from the analysis of these samples. The numerical data in Table 2 do not include any special samples.

TABLE 2. Numerical Data on the Routine Ground-Water Monitoring Progam. 1982

Number of Number of Number of Area Wells Sampled Samples Taken Analyses Made

\begin{tabular}{|c|c|c|c|}
\hline 100 & 48 & 223 & 97 \\
\hline 200 & 22 & 96 & 264 \\
\hline 300 & 28 & 136 & 822 \\
\hline \multirow[t]{2}{*}{$600(a)$} & 226 & 1012 & 2558 \\
\hline & 324 & 1467 & 3741 \\
\hline
\end{tabular}

(a) The 600 Area encompasses all of the Hanford Site not included in the other operating areas $(100,200,300$ Areas $)$.

\section{TRITIUM CONCENTRATION IN THE UNCONFINED GROUND WATER}

Because tritium $\left({ }^{3} \mathrm{H}\right)$ enters the ground-water system as part of the water molecule, it is carried along with the ground-water flow and remains almost unaffected by the geologic conditions that affect other radionuclides. Tritium, therefore, provides a good indication of the movement of ground water at the Hanford Site. Figure 5 shows the distribution of ${ }^{3} \mathrm{H}$ in the unconfined aquifer. Appendix A contains the concentrations of ${ }^{3} \mathrm{H}$ found in samples collected in 1982.

The configuration of the largest tritium plume, which lies between the 200 Areas and the
Columbia River, has changed very little in the past year. Concentrations of tritium in Well 69940-1, shown in Figure 6 , have increased only slightly since 1981, which indicates that the area of higher concentration ( 300 to $\sim 850 \mathrm{pCi} / \mathrm{ml}$ ) within this plume has not yet reached the Columbia River. Figure 7, which is a graphic illustration of the concentration history of tritium for Well 699-35-9, shows essentially the same results.

The area of higher concentration ( 300 to $\sim 850$ $\mathrm{pCi} / \mathrm{ml}$ ) within the largest plume is moving toward the river, as is indicated by the concentration histories of Wells 699-31-31 and 699-41-23 (Figures 8 and 9). The area of higher concentration has now passed by Well 699-31-31, as indicated by the decline in the tritium concentration to below $300 \mathrm{pCi} / \mathrm{ml}$. While the concentration in Well 699-41-23 continues to decline, it has not yet dropped below $300 \mathrm{pCi} / \mathrm{ml}$.

Concentration histories of wells elsewhere within the plume reflect local hydrogeological conditions. The concentration history of tritium in Well 699-2-3 (Figure 10) is in apparent equilibrium at or near $110 \mathrm{pCi} / \mathrm{ml}$. Ground-water flow in the vicinity of this well is such that concentrations should remain at or near this level for several years.

Figure 11 shows that the tritium concentration in Well 699-9-E2 dropped through mid-1972, had a gradual increase until 1978, and then declined to the present low level. Although Wells 699-9-E2 and 699-2-3 show different concentration trends, both are used to monitor the southern portion of the tritium plume. Well 699-9-E2 represents an area of low hydraulic conductivity, which retards the movement of ground water. Well 699-2-3 represents an area of high hydraulic conductivity, through which ground water moves at a more rapid rate. These differences in the hydrogeology help to explain the observed differences in the concentration histories of these wells.

Figure 12 shows a concentration history for Well 699-87-55. The graph, with its sinusoidal pattern, illustrates a dynamic system affected by changes in river flow, precipitation, reactor operations, and hydrogeology. This well is located about $1,8 \mathrm{~km}$ from $\mathrm{N}$ Reactor. 


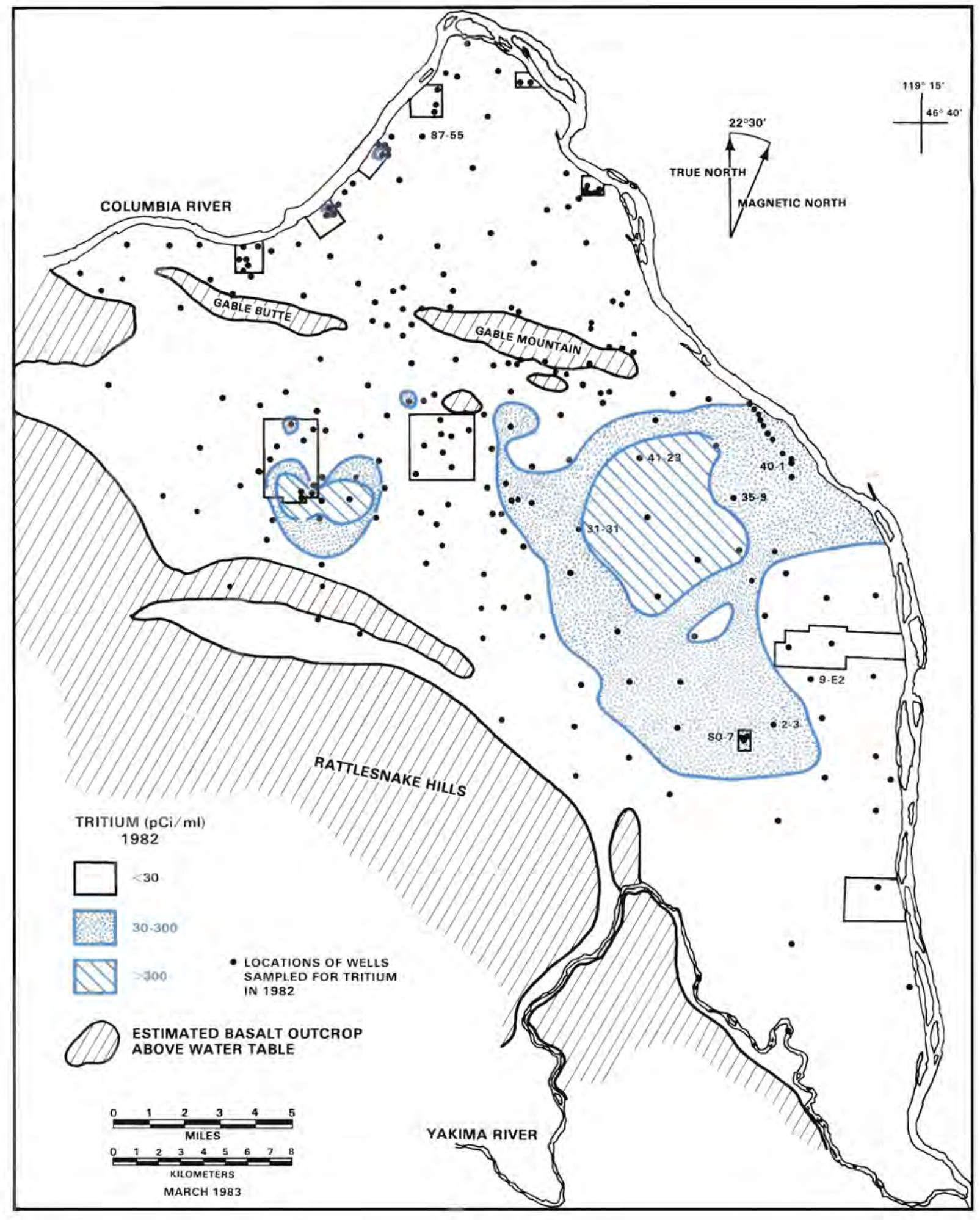

FIGURE 5. Tritium Distribution in Unconfined Ground Water 


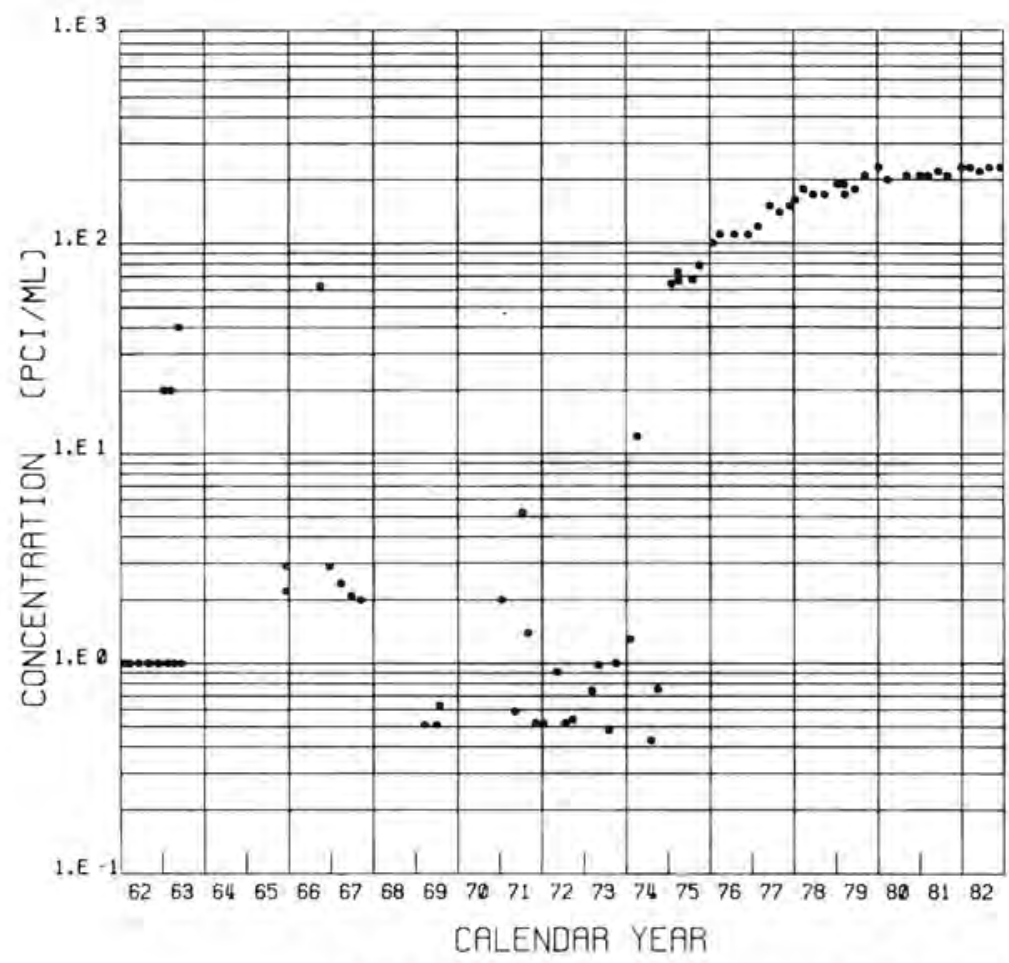

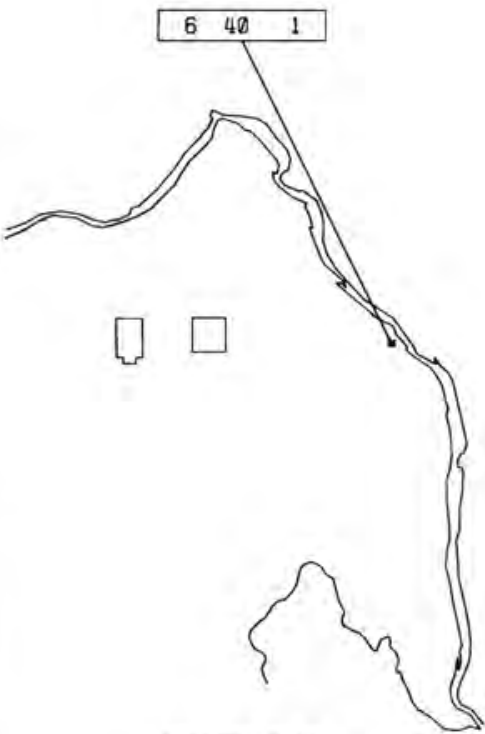

HANFORD SITE

FIGURE 6. Concentration History for Tritium in Well 699-40-1
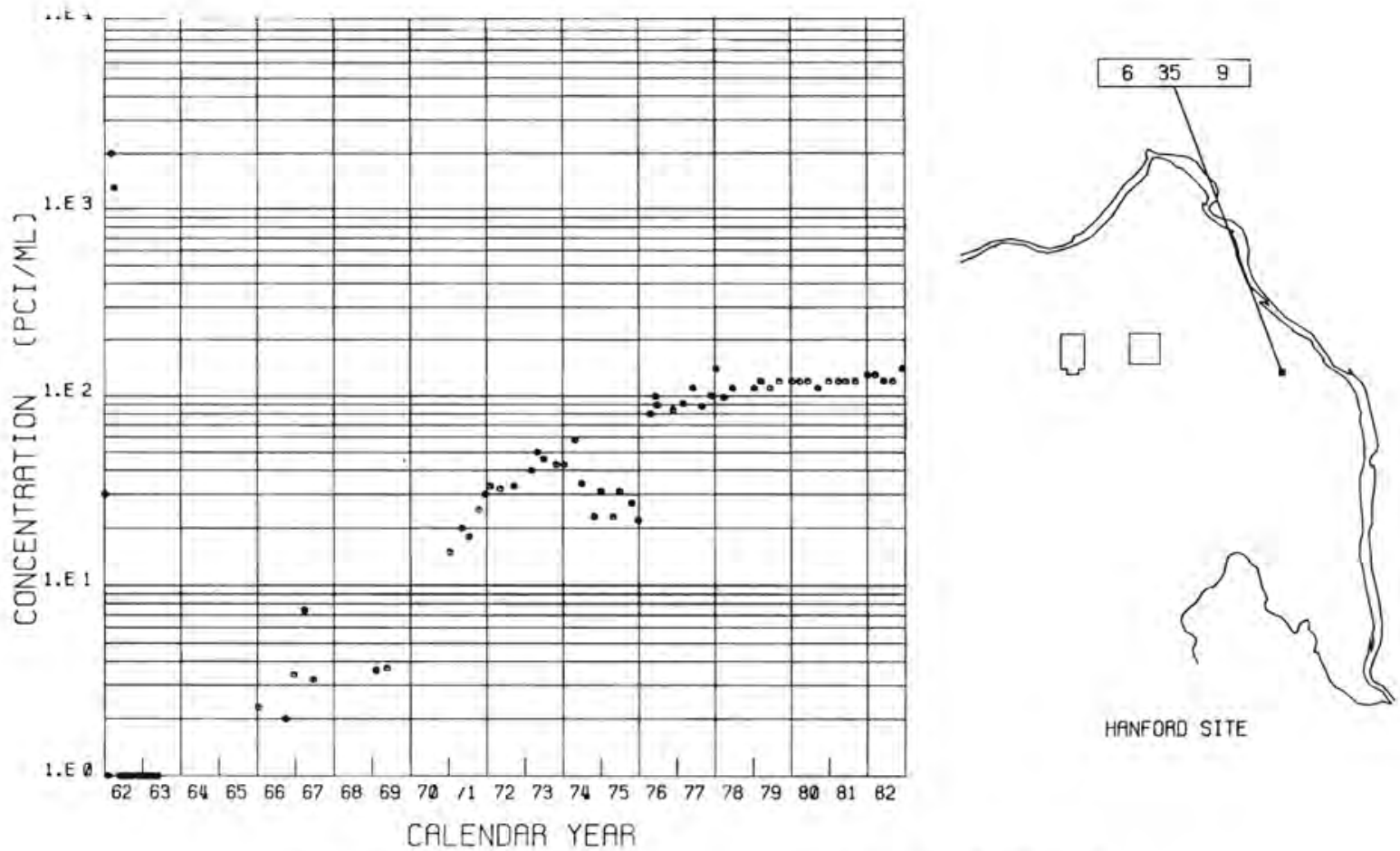

HANFORD SITE

FIGURE 7. Concentration History for Tritium in Well 699-35-9 


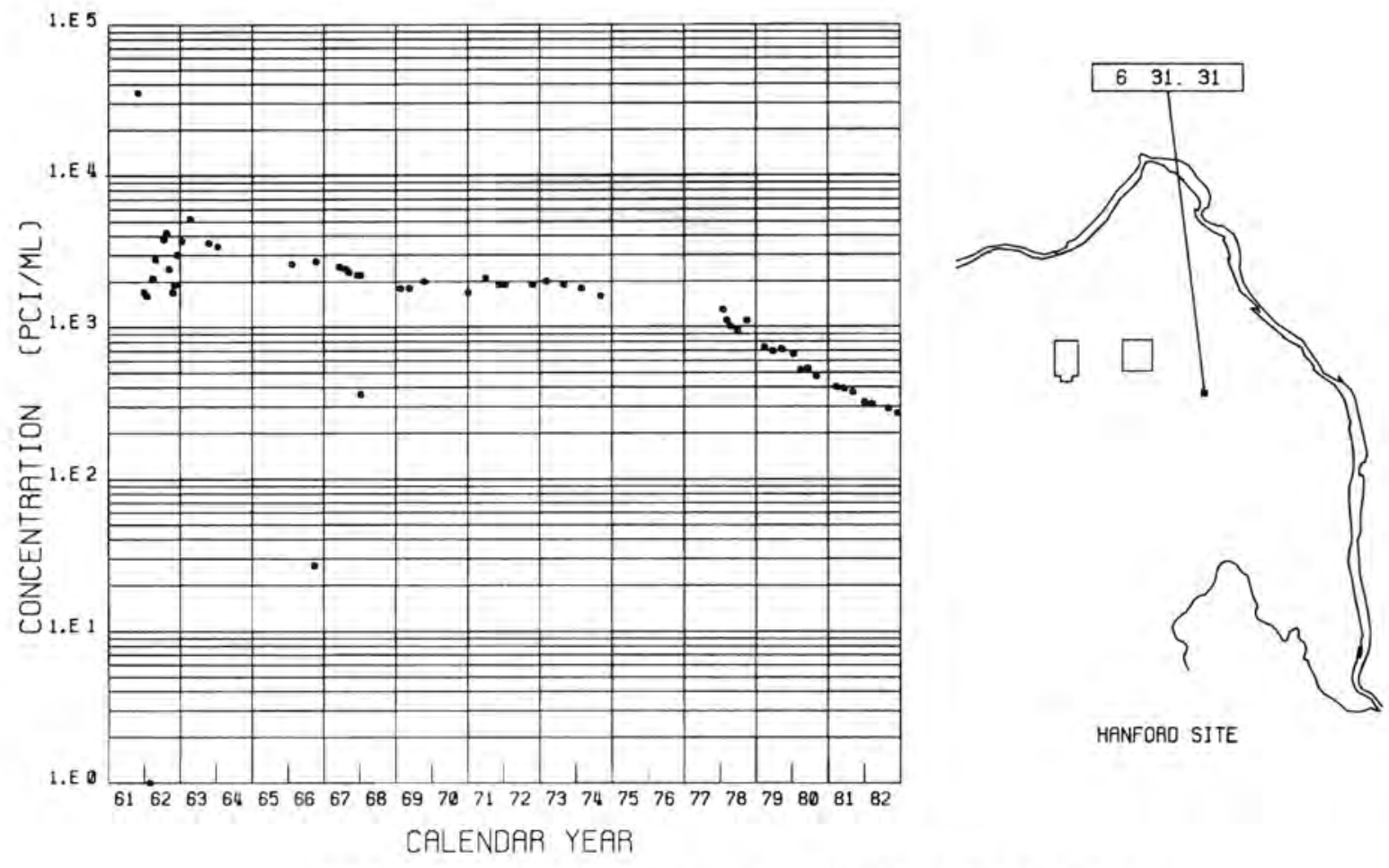

FIGURE 8. Concentration History for Tritium in Well 699-31-31
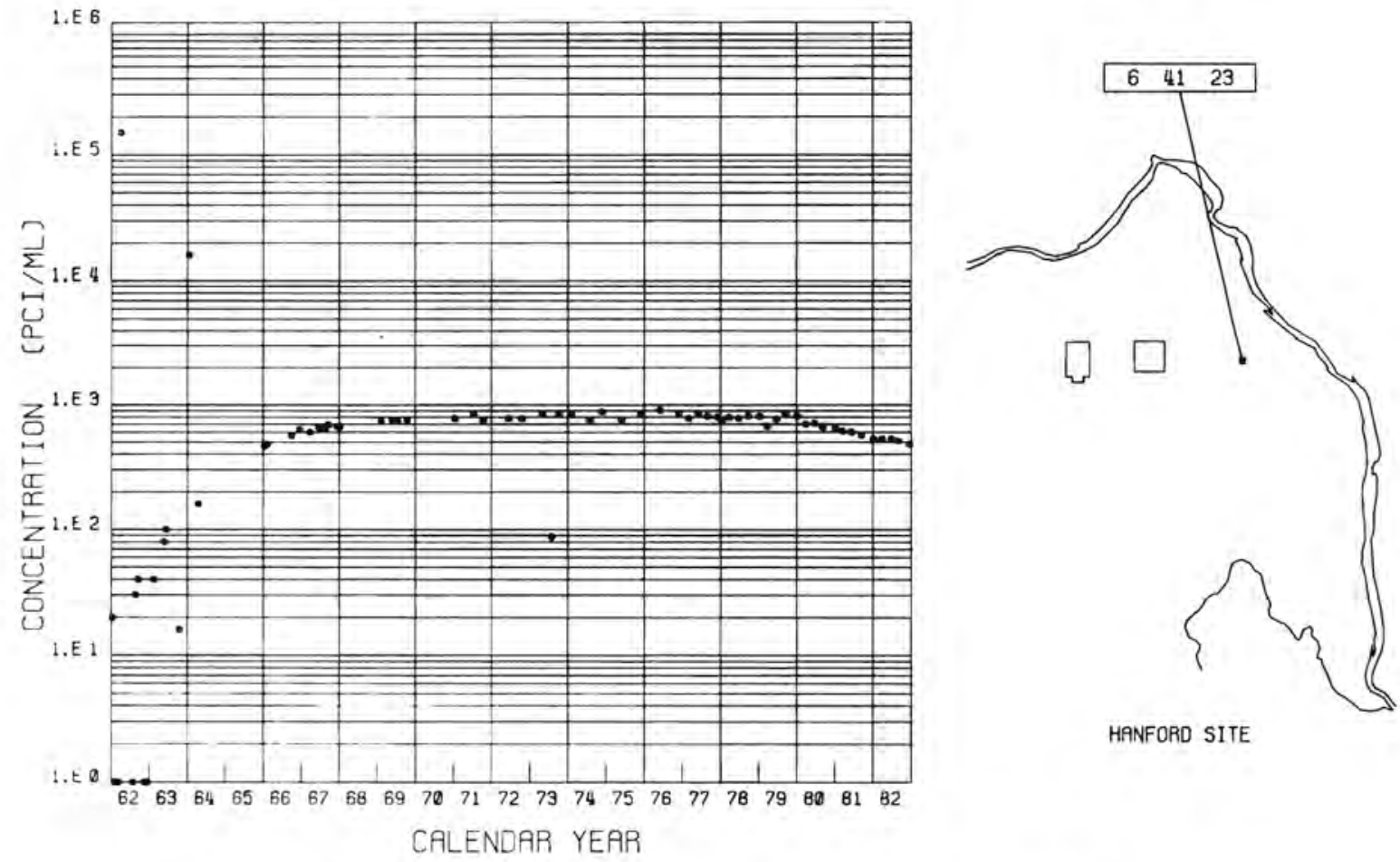

HANFORD SITE

FIGURE 9. Concentration History for Tritium in Well 699-41-23 

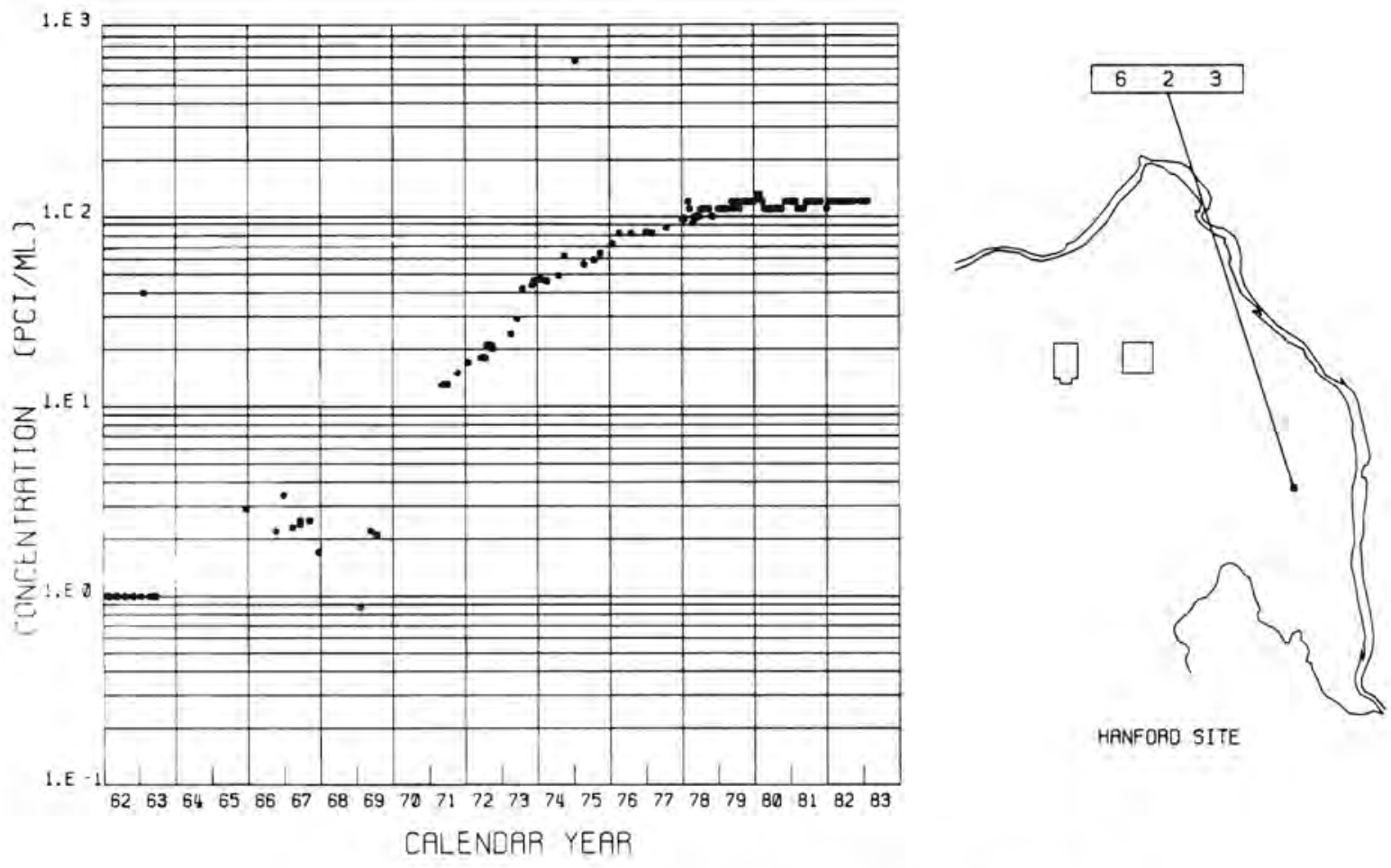

HANFORO SITE

FIGURE 10. Concentration History for Tritium in Well 699-2-3
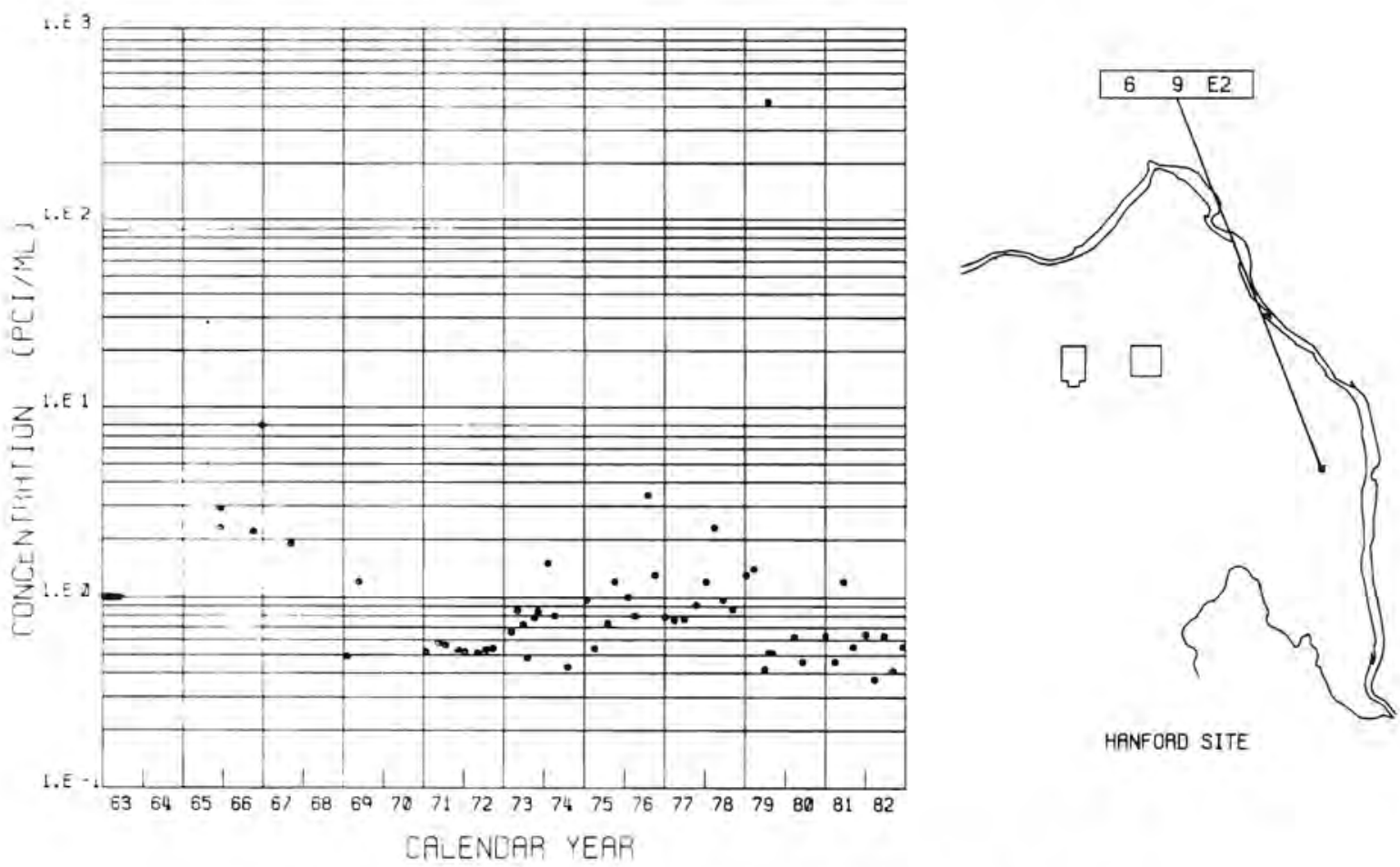

HANFOAD SITE

FIGURE 11. Concentration History for Tritium in Well 699-9-E2 

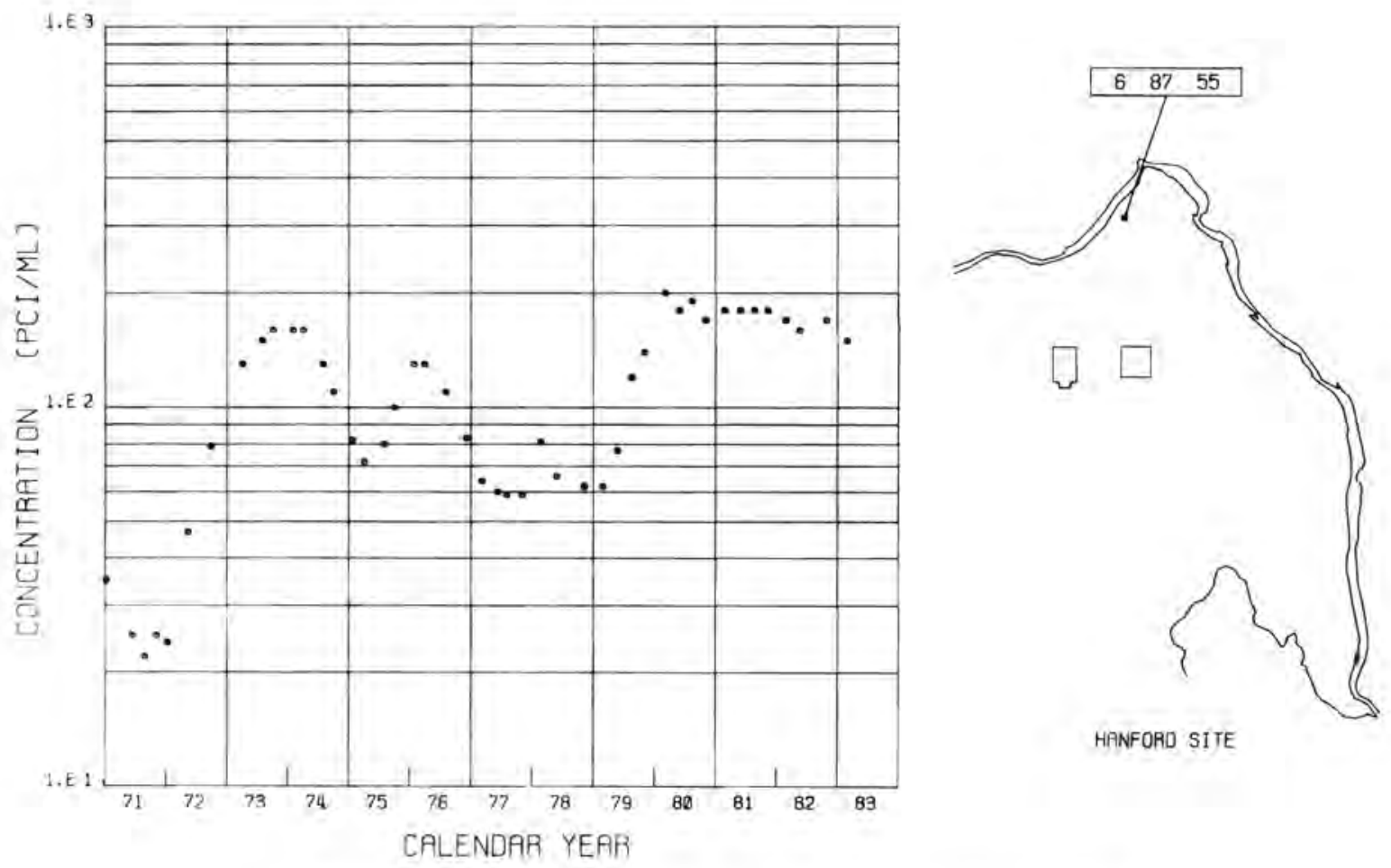

HANFORD SITE

FIGURE 12. Concentration History for Tritium in Well 699-87-55

\section{NITRATE CONCENTRATION IN THE UNCONFINED GROUND WATER}

Figure 13 shows the concentration and distribution of nitrate $\left(\mathrm{NO}_{3}^{-}\right)$in the ground water at $\mathrm{Han}$ ford. Appendix A contains data on the maximum, average, and minimum concentrations. Data collected in 1982 indicate little areal change in the nitrate plume. Zones of elevated nitrate concentrations persist in the vicinity of the 200-E, 200-W, $100-\mathrm{F}$, and $100-\mathrm{H}$ Areas, and in the central portion of the main ground-water contamination plume. A decrease of nitrate concentration continues in Well 699-32-43 (Figure 14), where a cyclical pattern reflects the operational history of the 200-E Area. This cyclical pattern is also seen in the concentration history of Well 699-3222 (Figure 15). The slight decline in the nitrate concentration in this well for the last few years may indicate that the area of higher concentration ( $>45 \mathrm{ppm})$ within the plume is about to pass the well.

Well 199-H4-3 was drilled specifically to monitor a solar evaporation facility at the $100-\mathrm{H}$ Area. The facility consists of a concrete basin used as a concentrator for waste generated by fuel fabrication activities in the 300 Area. Wastes placed in the basin normally contain copper, sodium, nitrate, and sulphate, with small amounts of other consitituents, such as chromium. The wastes do not contain radioactive materials other than trace amounts of uranium. An unknown quantity of the solute leaked from the basin through joints or fractures in the concrete and eventually reached the ground water. Corrective action was initiated in 1979, which included sealing the leak in the basin. As shown in Figure 16, there has been a general decline in the nitrate concentration in Well 199-H4-3 since the corrective work was done.

Although the data appear to be scattered, the nitrate concentration in Well 699-SO-7 (Figure 17) is generally declining with time. The lowering of the nitrate level in this well is probably due to the development of a deeper portion of the aquifer that has a lower level of nitrate (Eddy, Myers, and Raymond 1978) rather than a decrease in the nitrate plume concentration in this area. 


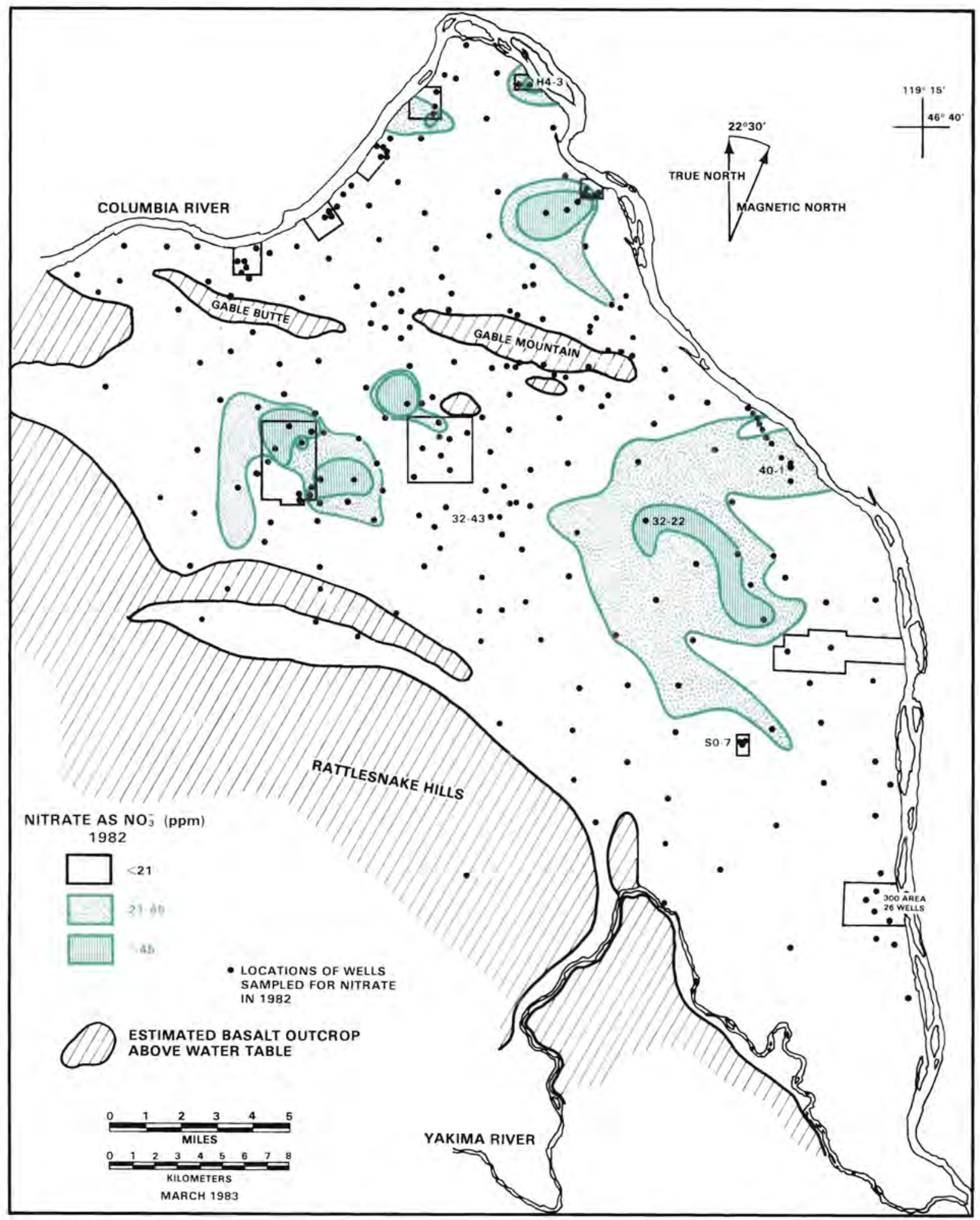

FIGURE 13. Nitrate Ion Distribution in Unconfined Ground Water 

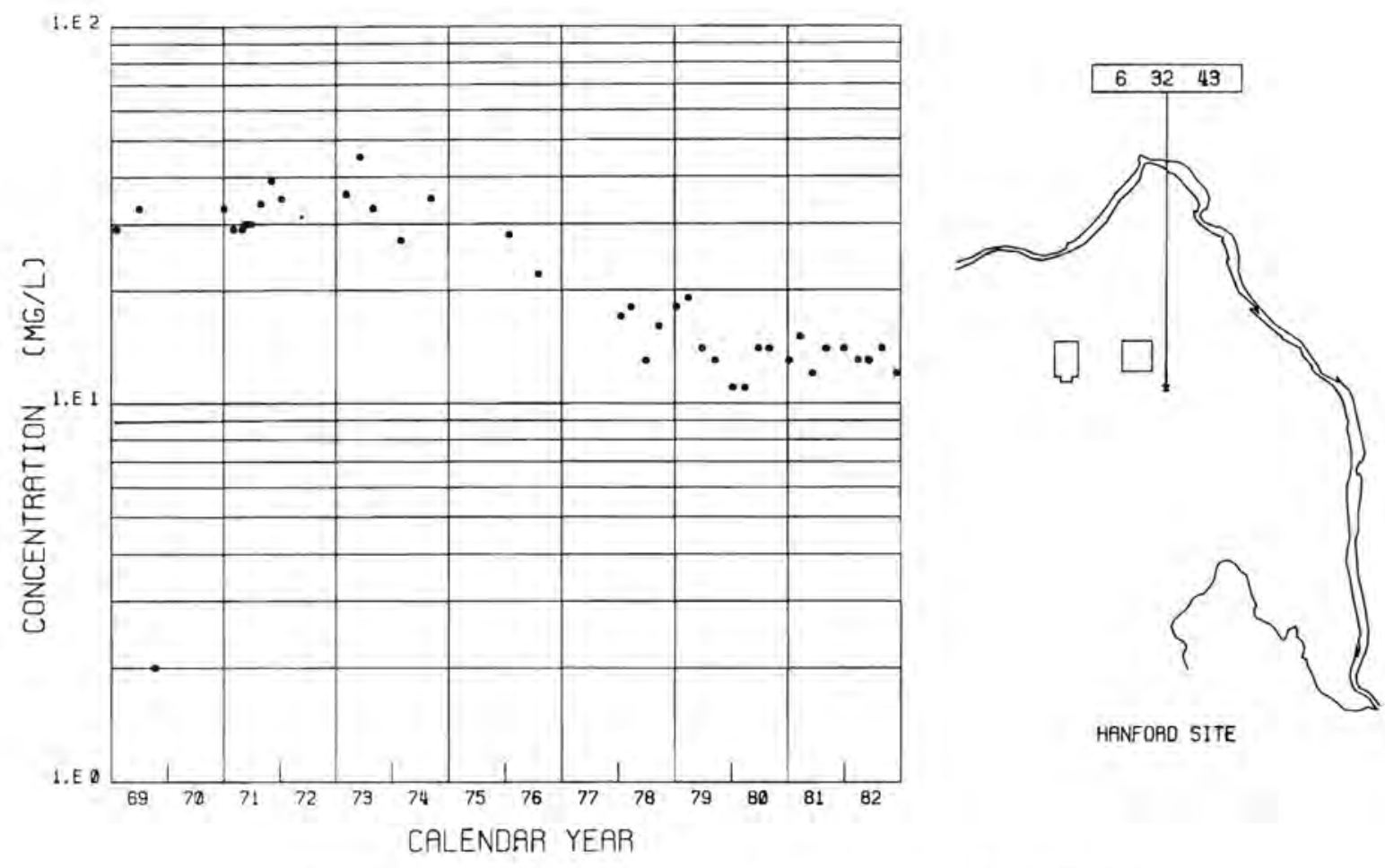

HANFORD SITE

FIGURE 14. Concentration History for Nitrate in Well 699-32-43
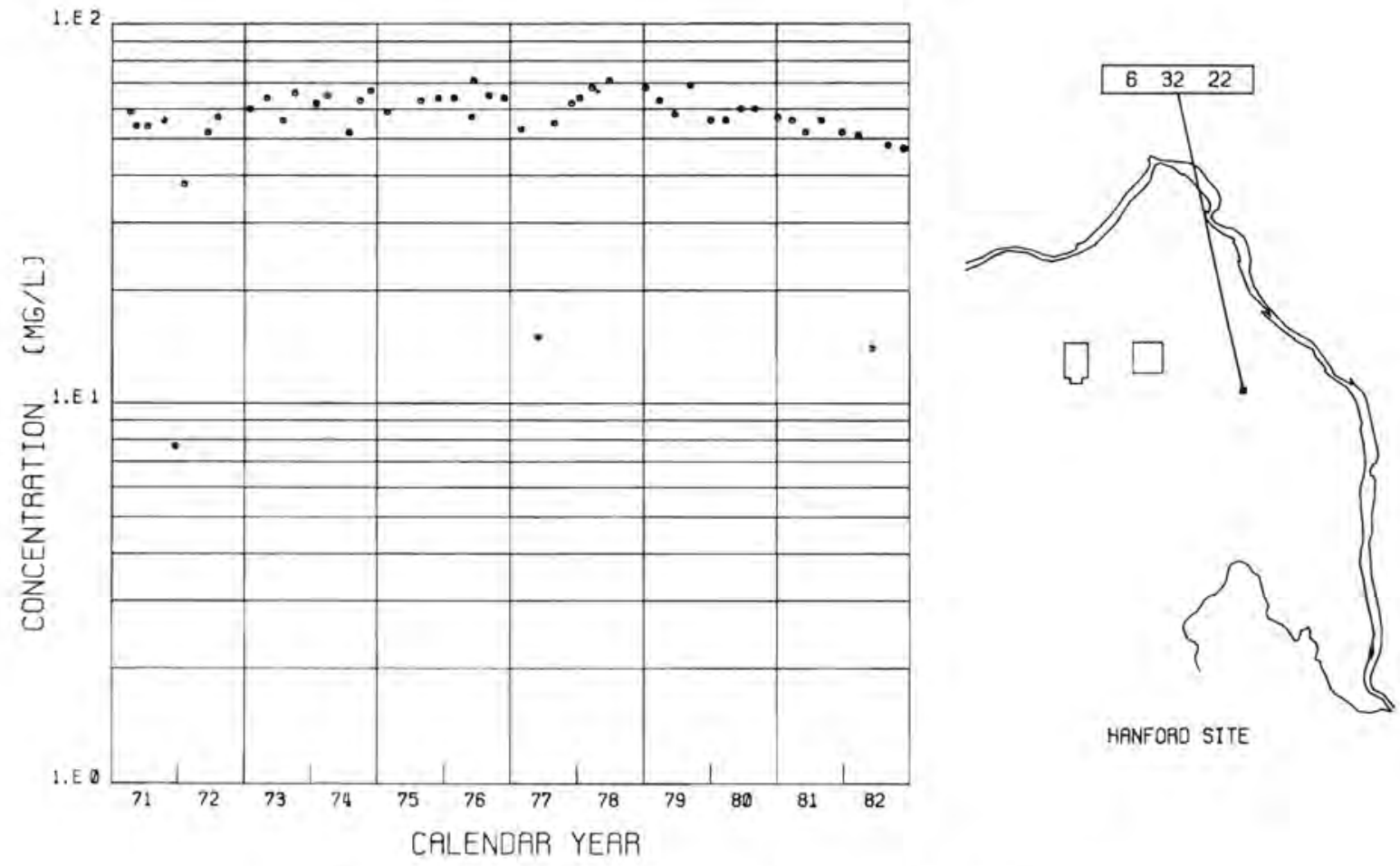

HANFORD SITE

FIGURE 15. Concentration History for Nitrate in Well 699-32-22 

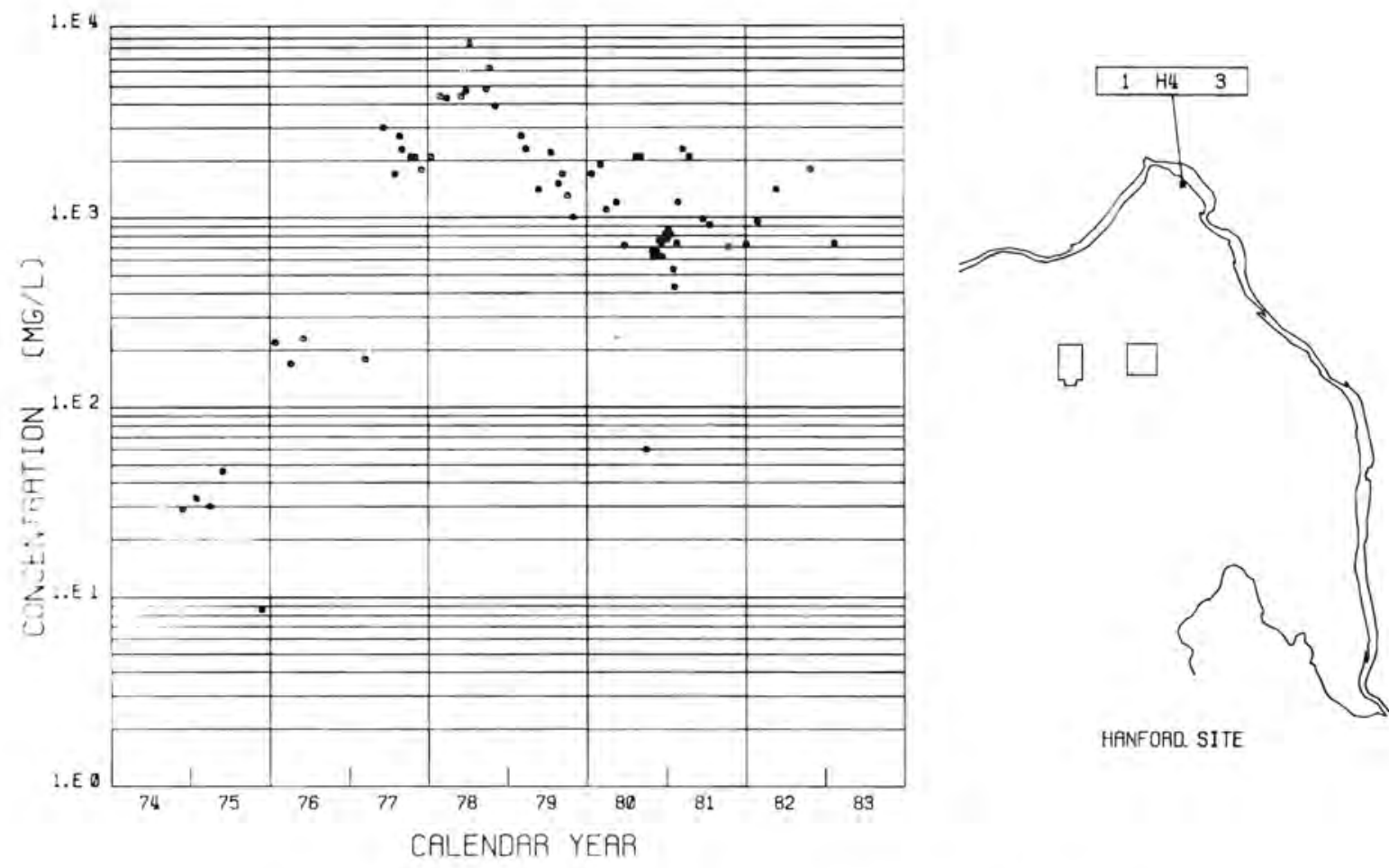

HANFORD. SITE

FIGURE 16. Concentration History for Nitrate in Well 199-H4-3
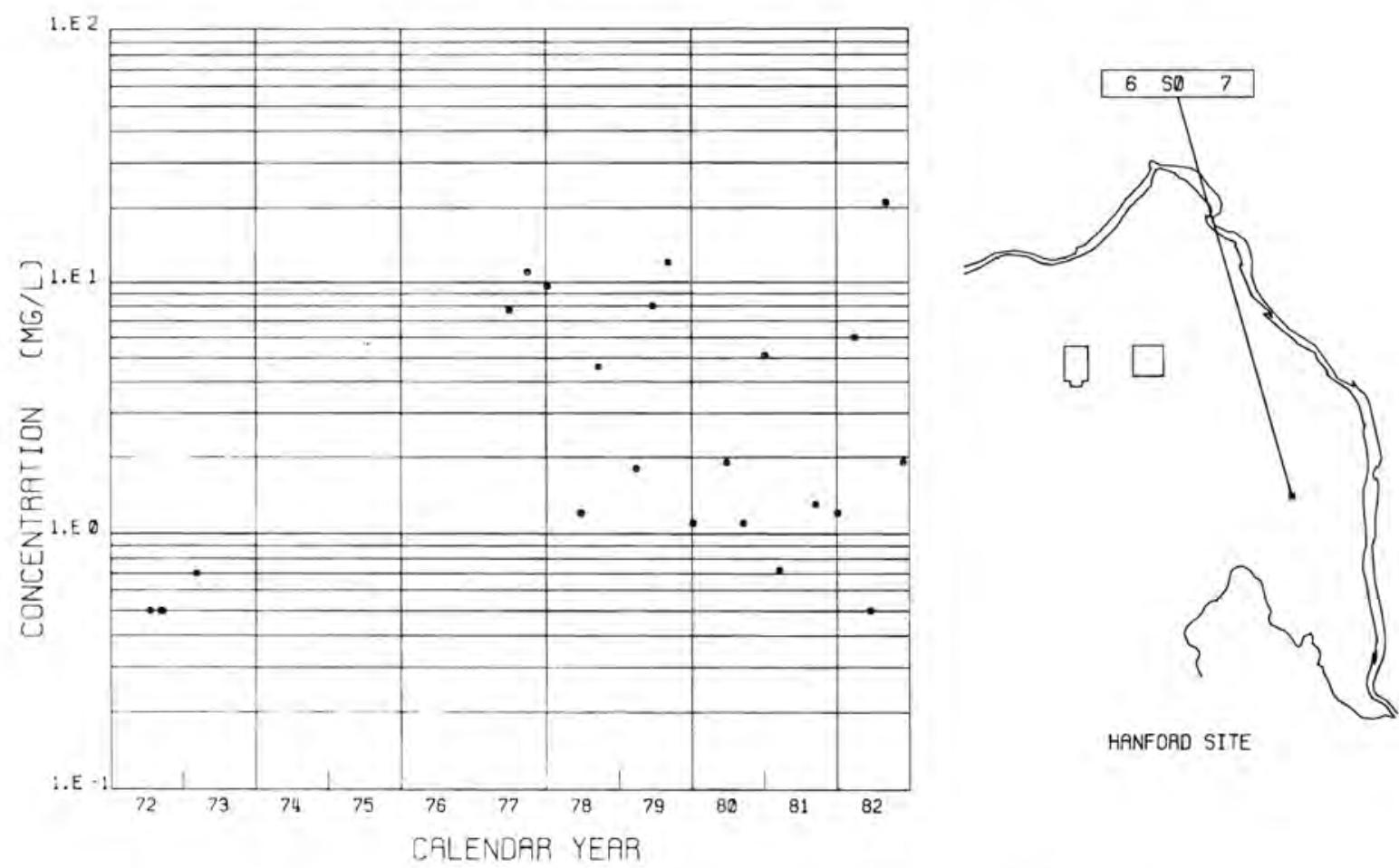

HANFOAD SITE

FIGURE 17. Concentration History for Nitrate in Well 699-S0-7 
The configuration of the nitrate plume has not changed significantly. However, the high level of nitrate in Well 699-40-1 (Figure 18) indicates that the nitrate in the ground water resulting from plant operations has reached the Columbia River.

\section{GROSS BETA CONCENTRATION IN THE UNCONFINED GROUND WATER}

The concentration and distribution of gross beta radioactivity in the Hanford ground water have been decreasing for several years, as shown in previous years' reports (Eddy and Wilbur 1981). The concentrations are now at insignificant levels in most of the aquifer. The few remaining areas of higher levels are located mainly at or very near the 200 West and 200 East Areas and the $100-\mathrm{N}$ reactor site. Since these areas are very small, a map of the gross beta distribution in the ground water was not generated for the 1982 calendar year.
Gross beta activity in and near the 200 Areas is the result of operating and maintaining the reprocessing facilities for irradiated uranium fuels and disposing of contaminated liquids to cribs (Wilbur and Graham 1982). The gross beta activity in or near the $100-\mathrm{N}$ reactor site is caused by the reactor site operations and by the liquid waste disposal to the $1301-\mathrm{N}$ trench/crib (Greager 1982).

The changes in gross beta activity in the unconfined ground water with time result from the cyclical nature of the Hanford plants as they start up and shut down their operations. The gross beta concentrations reached a peak in early 1971 , and since then both the concentration levels and the overall size of the plume have decreased. This trend will probably continue until the fuel reprocessing facilities are returned to operation.

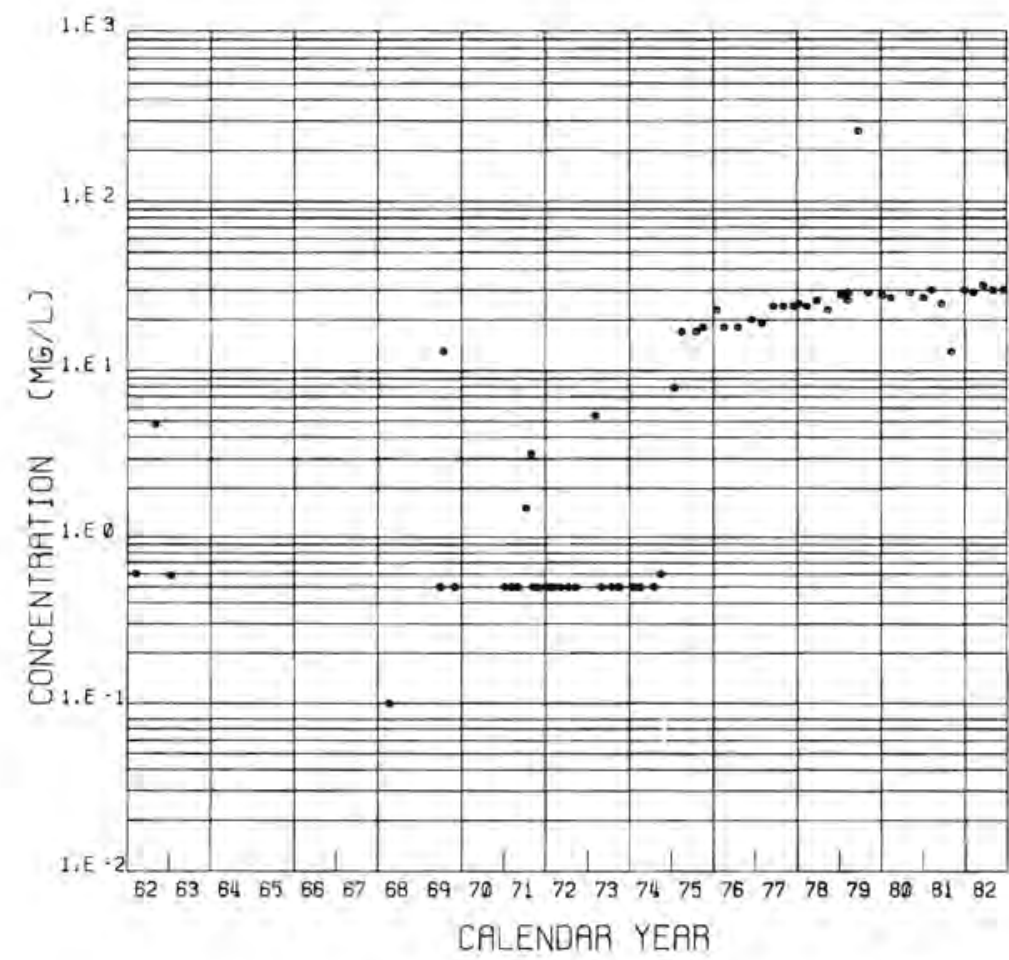

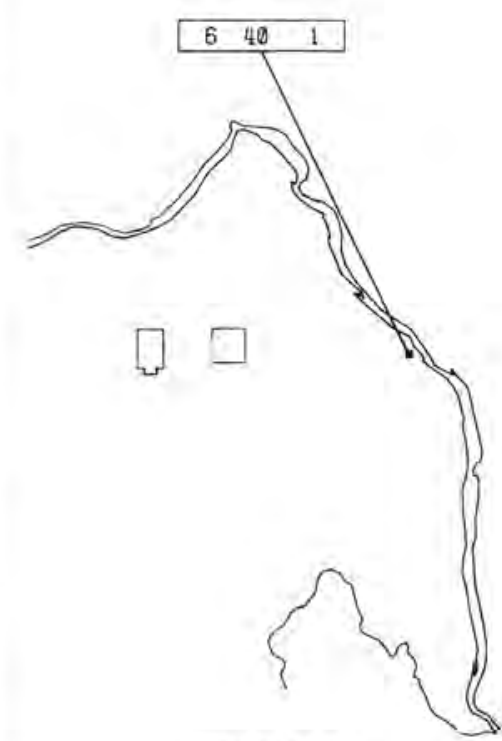

HANFORD SITE

FIGURE 18. Concentration History for Nitrate in Well 699-40-1 


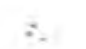

-

+

Q

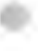

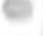

6

e 


\section{RADIOLOGICAL IMPACT}

Ground-water transport of radionuclides at the Hanford Site represents a potential pathway for exposure to radiation via water obtained from wells that tap the unconfined aquifer or from the Columbia River into which the unconfined aquifer discharges. The following discussion examines these potential pathways.

\section{GROUND WATER}

During 1982, drinking water for the FFTF was obtained from the unconfined aquifer. The drinking water at FFTF contains elevated concentrations of tritium from past effluent disposal in the 200 Areas (Figure 19).

The whole body dose attributable to the tritium in drinking water at FFTF in 1982 (average $\sim 18$ $\mathrm{pCi} / \mathrm{m \ell}$ ) is calculated to be $0.3 \mathrm{mrem}$, based on an ingestion rate of $250 \mathrm{f} / \mathrm{yr}$ (approximately half of the average adult water consumption per year). The 50-year dose commitment from tritium is the same as the annual dose because of the relatively short biological half life of this radionuclide $(\sim 12$ years). This estimated whole body dose from Hanford operations is less than the amount reported last year (Eddy, Cline, and Prater 1982). The calculated dose is less than $10 \%$ of the state of Washington drinking water standards.

Additional monitoring of drinking water systems at Hanford (including three systems that use ground water) is conducted by the Hanford Environmental Health Foundation. Information on this effort can be obtained from Maas (1982).

\section{COLUMBIA RIVER}

Ground water entering the Columbia River from the Hanford Site is diluted by several orders of magnitude because of the difference between the river and ground-water flow rates. During 1982, the average Columbia River flow rate at Priest Rapids Dam was reported by the U.S. Geological Survey (1983) as $140,000 \mathrm{cfs}\left(3965 \mathrm{~m}^{3} / \mathrm{sec}\right)$.

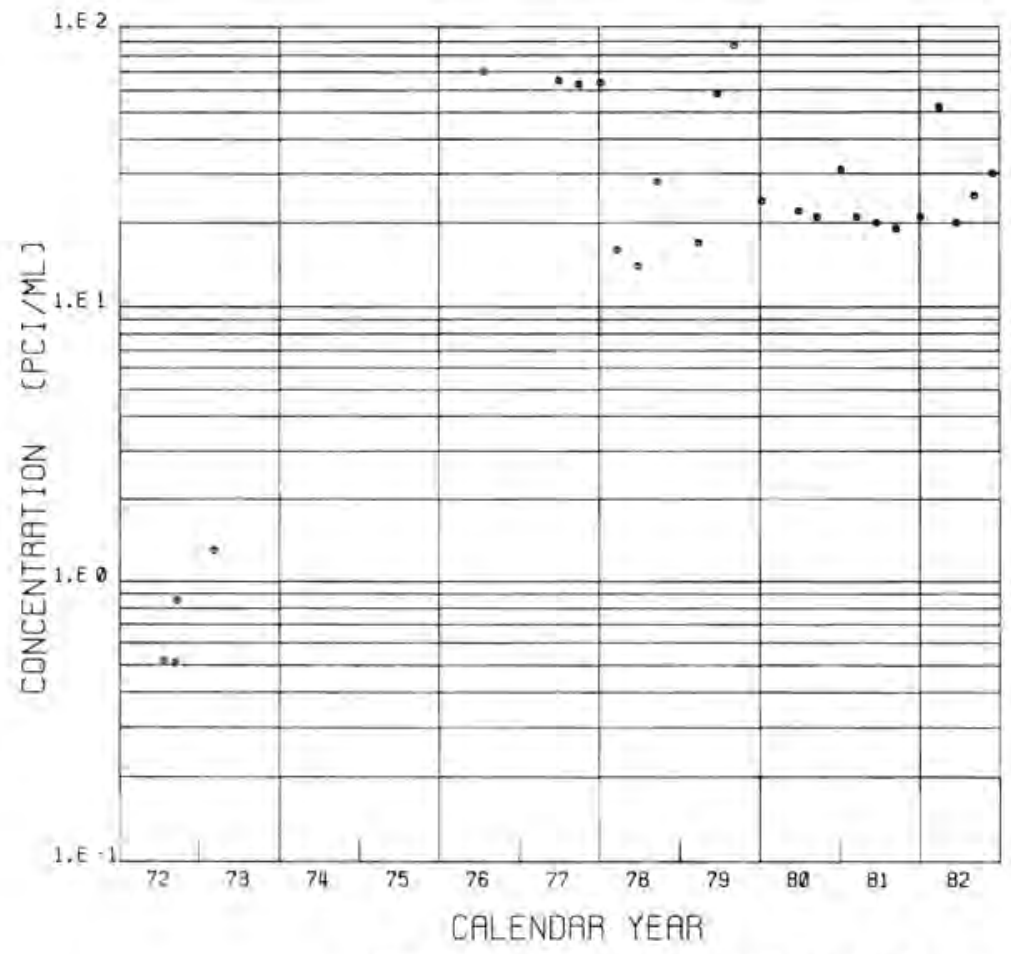

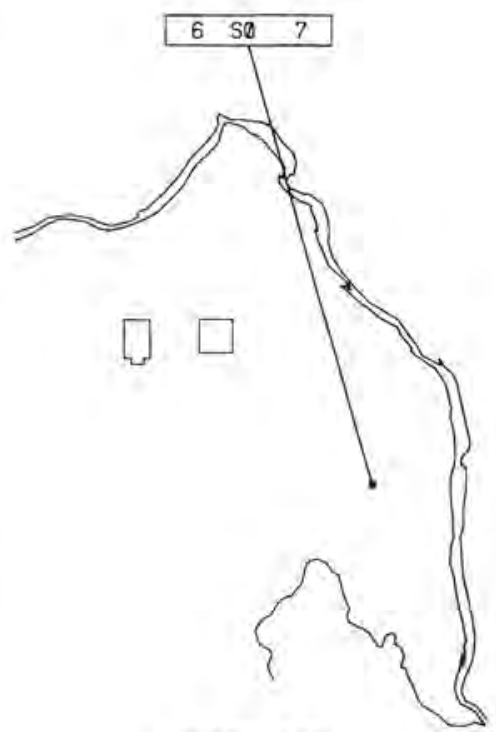

HANFORD SITE

FIGURE 19. Concentration History for Tritium in Well 699-S0-7 
The flow rate from the unconfined aquifer into the Columbia River has been estimated to be about $100 \mathrm{cfs}\left(2.8 \mathrm{~m}^{3} / \mathrm{sec}\right.$ ) (Myers 1978).

Tritium concentrations measured in wells near the river in 1982 were in the range of approximately 1 to $200 \mathrm{pCi} / \mathrm{ml}$. In 1982 , the average tritium concentrations in the Columbia River were $0.2 \mathrm{pCi} / \mathrm{m \ell}$ (Sula et al. 1983). As discussed in PNL-4657 (Sula et al. 1983), the contribution of tritium to the Columbia River from the aquifer during 1982 was not sufficient to be accurately measured in the presence of the background concentrations resulting from worldwide fallout. 


\section{RESULTS OF SUPPORTING STUDIES}

Several studies are conducted in support of the Ground-Water Surveillance Program. These studies provide additional data to help characterize the ground-water system, refine the hydrologic and transport models, and determine the impact of Site operations on the environment. The results of four studies conducted during $\mathrm{CY}$ 1982 are described in this chapter.

\section{BANK STORAGE STUDY}

When a river rises, ground-water levels are temporarily raised by inflow from the river. The volume of water stored and released after the river drops is called bank storage (Todd 1980).

Evaluation of bank storage began in October
1981 to obtain information about interactions of the Columbia River and the unconfined aquifer. Since the tritium and nitrate plumes have reached the Columbia River, knowledge of the aquifer/ river interactions can assist in evaluating the effects of bank storage on the quantity of radionuclides and chemicals entering the Columbia River as a function of time.

One way to study bank storage is to compare changes in the water table at various distances from the river with changes in river level. As a means of doing this, continuous water-level recorders have been installed in wells near the old Hanford Townsite as shown in Figure 20. These wells are located 200 to 5000 feet from the river.

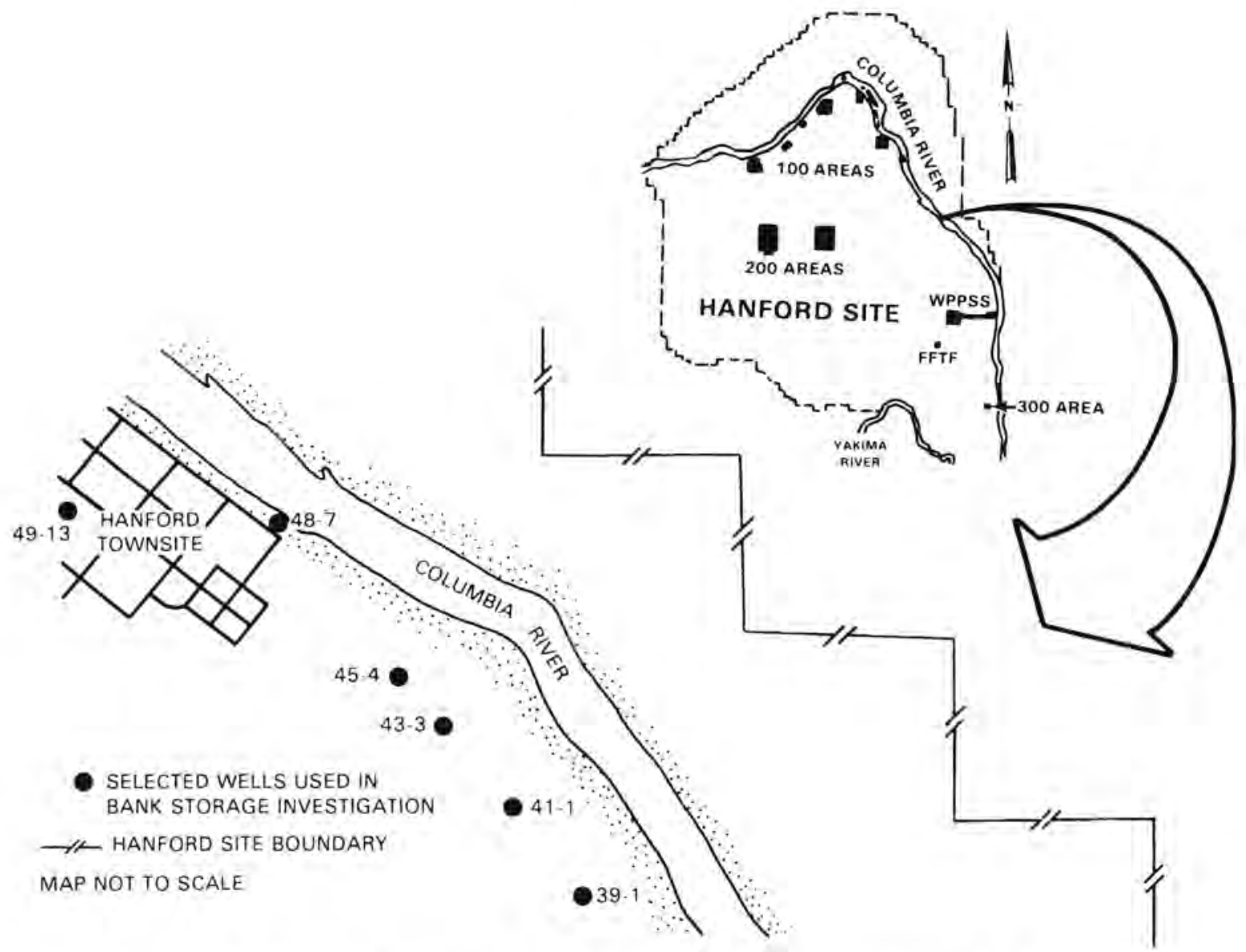

FIGURE 20. Locations of Selected Wells Used in the Bank Storage Study 

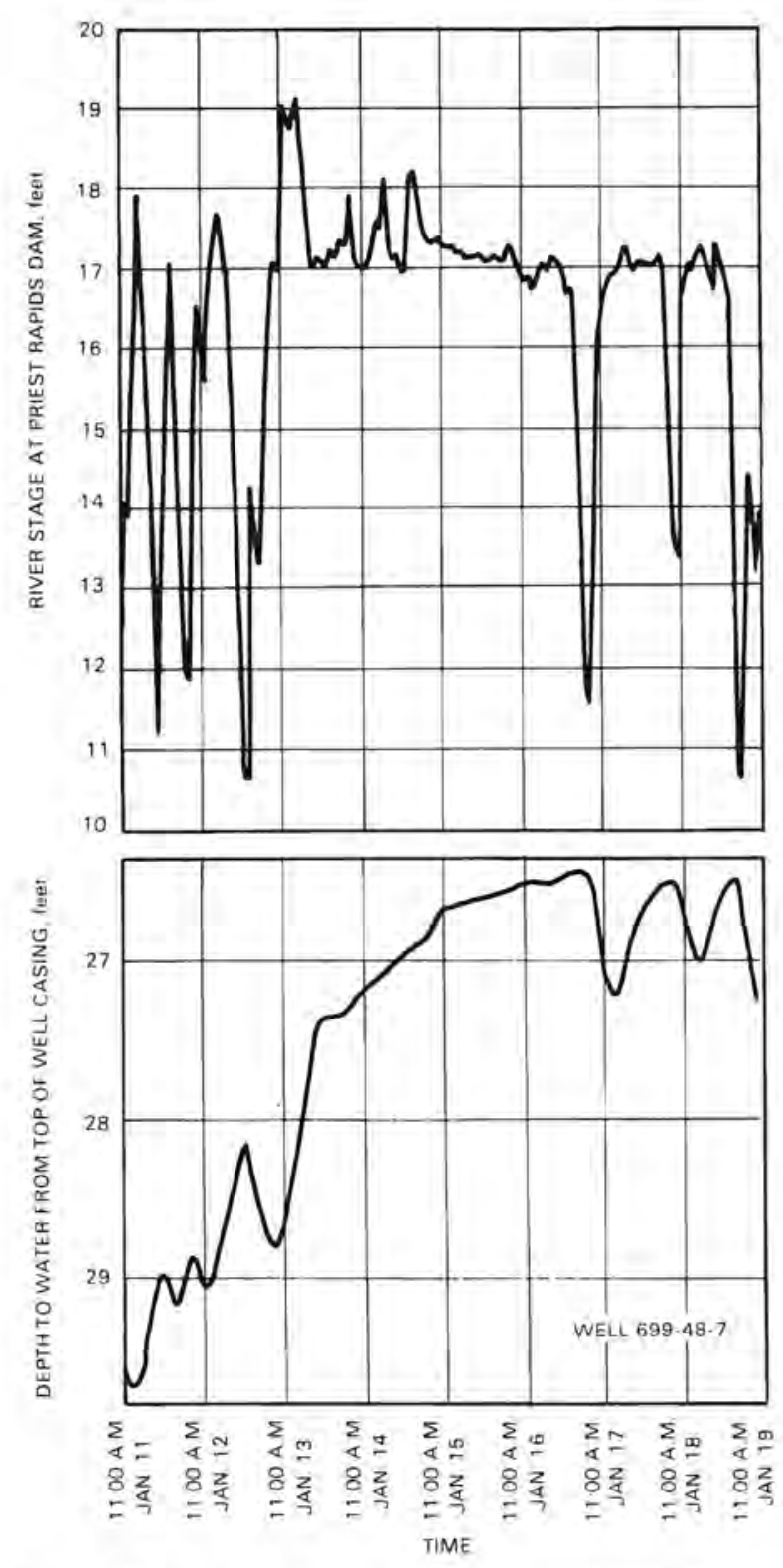

FIGURE 21. Changes in the Water Level in Well 69948-7 Compared with Changes in the River Stage at Priest Rapids Dam

Figure 21 shows a one-week record of water levels in Well 699-48-7 compared to a record of the gage height of the Columbia River just below Priest Rapids Dam (approximately 35 miles upstream from the Hanford Townsite). Water level changes in the well follow the same pattern as the gage height changes in the river, although they are of a smaller magnitude. There is also a

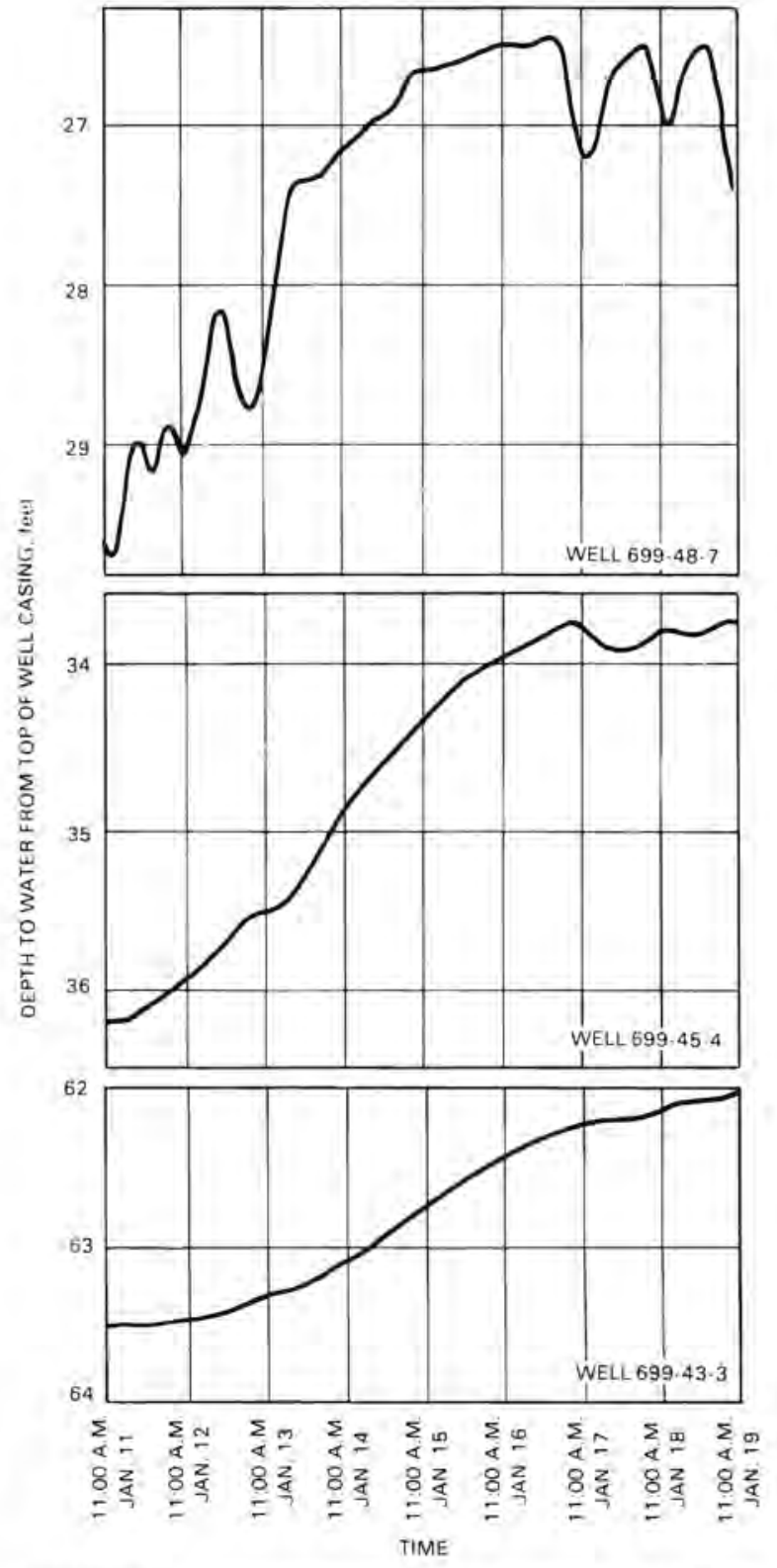

FIGURE 22. A Comparison of Changes in the Water Levels in Wells 699-43-3, 699-45-4, and 699-48-7

lag between peak levels in the well and the river due to the travel time of the surge of water downstream and the time needed for river water to infiltrate the bank.

Figure 22 shows a comparison of the changes in water level in three wells. Well 699-48-7 is nearest to the river, and it shows the largest fluctua- 
tions in water level. Well 699-43-3 is farthest from the river and shows the smallest changes. In addition, the lag time between peak level of the river and peak level in the well increases as the distance from the well to the river increases.

The bank storage effect is also indicated by seasonal fluctuations of the tritium concentrations in wells near the river. These concentrations decline as the river rises in the spring months and river water enters the bank; this trend is reversed when the river falls later in the year (Figure 23). Therefore, the analytical results of grab samples collected from wells near the river can vary greatly, depending on the time of year in which the samples are collected.

The Bank Storage Study will continue through FY 1983 with the study of water level changes, as well as a study of daily fluctuations in tritium concentrations in various wells.

\section{CLAY DEPOSIT INVESTIGATION}

An extensive, near-surface clay deposit that apparently acts as a partial barrier to groundwater flow has been discovered in the area southeast of the Hanford Townsite. This clay deposit was first encountered in 1980 when several new sampling wells were being installed near the river. A description of the clay deposit and an account of the special work conducted to define its areal extent are contained in the following paragraphs.

In 1979, several new sampling wells were constructed southeast of the townsite along a line running roughly parallel to the river (Figure 24). The following year, plans were made to construct a second line of wells closer to the river. The clay deposit was discovered when this second line of wells was drilled.
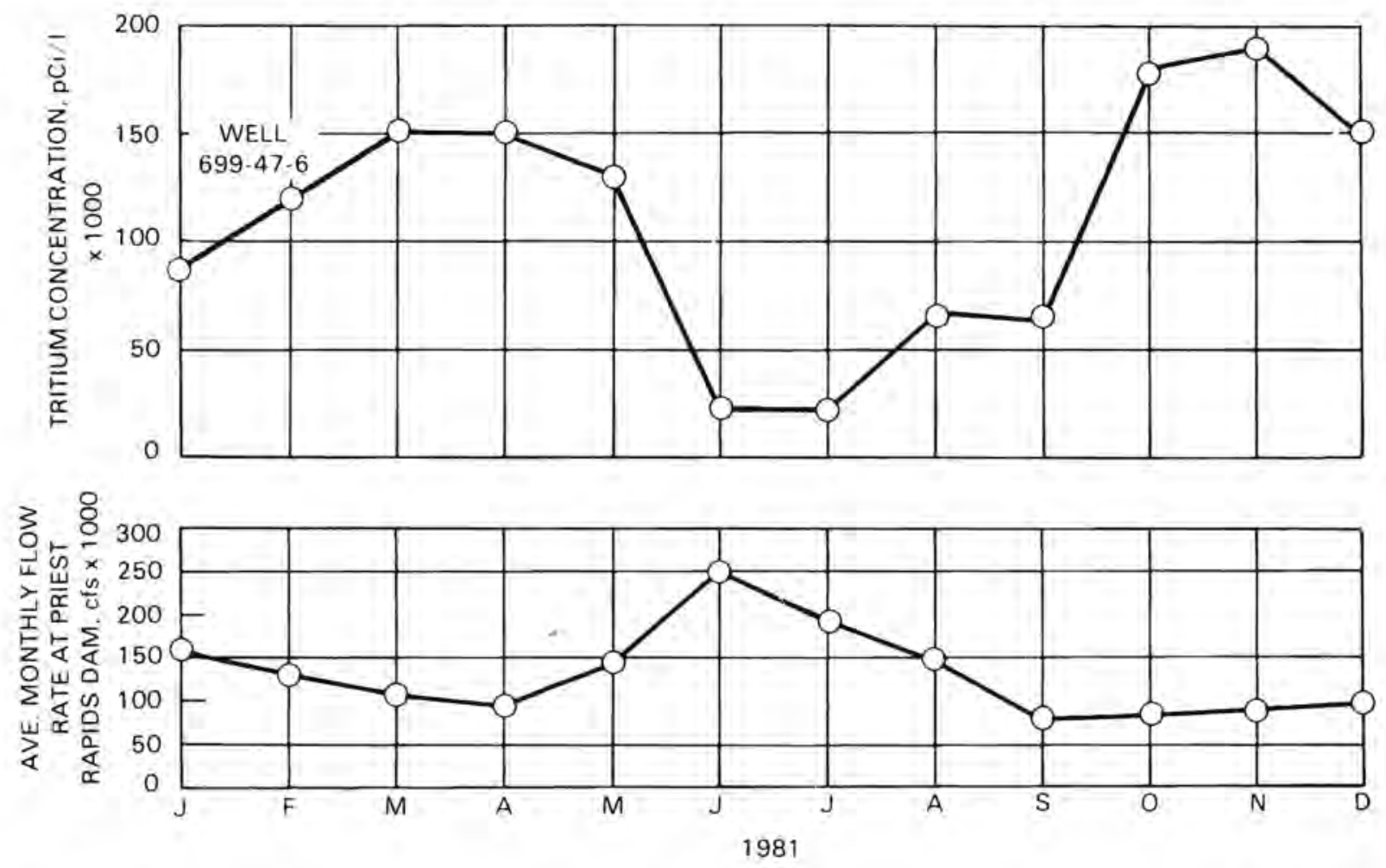

FIGURE 23. Changes in Tritium Concentrations in Well 699-47-6 Compared with Changes in the Flow Rate of the Columbia River 


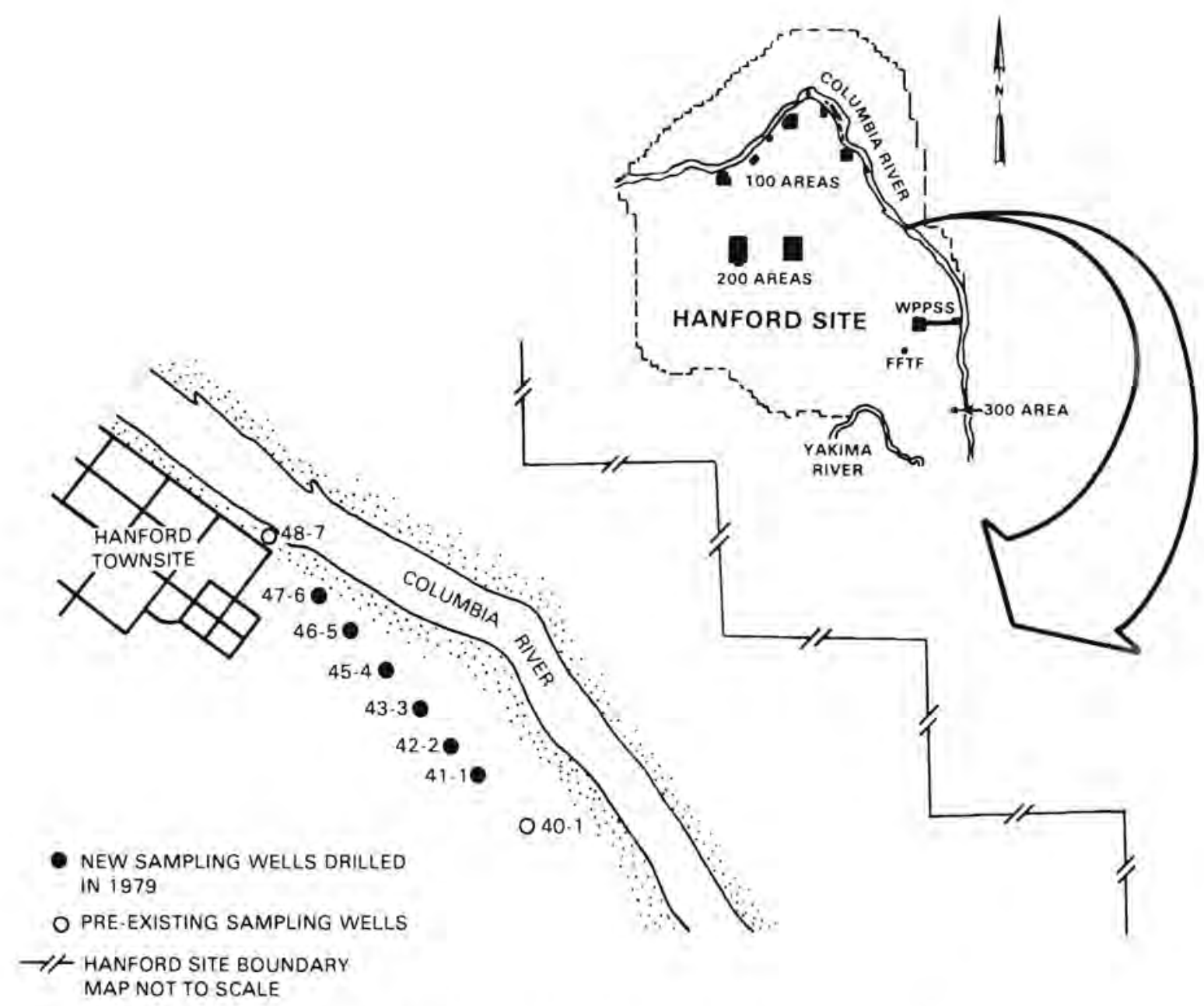

FIGURE 24. Locations of Selected Sampling Wells Drilled in 1979

In the first (i.e., northernmost) well to be drilled in the second line, a layer of brown, gray, and blue clay was encountered at a depth of about 9 meters ( $30 \mathrm{feet}$ ). This clay deposit extended down to a depth of about 21 meters (70 feet) where the drilling was stopped because no significant amount of water had been encountered. The depth to the unconfined ground water in this area is known to be about 7.5 to 10.5 meters (25-35 feet), so the clay deposit encountered in this well evidently prevents ground water from entering the well.

After pulling the casing for the first well, the driller filled in the hole and then moved further south to begin drilling another well. The same materials were encountered in this well at about the same depths. This well was also filled in and abandoned since no water was found.

The driller subsequently moved inland and started a third well (699-44-4). Although brown clay was encountered in this well at a depth of about 12 meters ( 40 feet), there was a waterproducing zone above the clay. The well was developed and added to the sampling network.

No additional drilling was done in this area until 1982 (two years later). At that time, the drilling effort was directed toward delineating the southern boundary of the clay deposit. For this purpose, three drilling sites further south from 
the abandoned wells were selected. At the first two of these three sites, the clay deposit was encountered during drilling and the wells were found to be dry. As before, these wells were filled in and abandoned. However, in the third (i.e., southernmost) well, the clay layer was not encountered. Unconfined ground water was found at a depth of 8 meters ( 26 feet). This well (699-39-E3) was thoroughly developed and prepared for use as a sampling well. Figure 25 shows the locations of the wells drilled in 1980 and 1982.

The approximate extent of the clay deposit, as determined by this drilling effort, is also shown in Figure 25. For the purposes of this map, the clay deposit is assumed to be continuous between drilling sites where it was encountered, although this is not necessarily a valid assumption.

Other research has revealed that the clay deposit acts as a partial barrier to the ground-water flow between the river and the unconfined aquifer. In particular, data collected under the Bank
Storage Study indicate that water levels in wells to the west (i.e., on the inland side) of the clay deposit do not fluctuate much in response to river flow rate changes (Figure 26). In contrast, the water levels in wells that are approximately the same distance from the river, but are either north or south of the clay deposit, show marked fluctuations in response to river flow rate changes (Figure 27). The stability of the water level in the wells west of the clay deposit indicates that this deposit partially inhibits the intrusion of river water as bank storage. Additional evidence for this effect is provided by the analysis of groundwater samples from the wells in this area. In particular, tritium concentrations in wells west of the clay deposit do not show the seasonal fluctuations exhibited by wells to the north of the clay deposit (Figure 28). These seasonal fluctuations in tritium concentrations have been correlated with the bank storage of river water. As the river flow rate increases in the spring months and river water enters the bank, the tritium concentrations in the wells decline; this

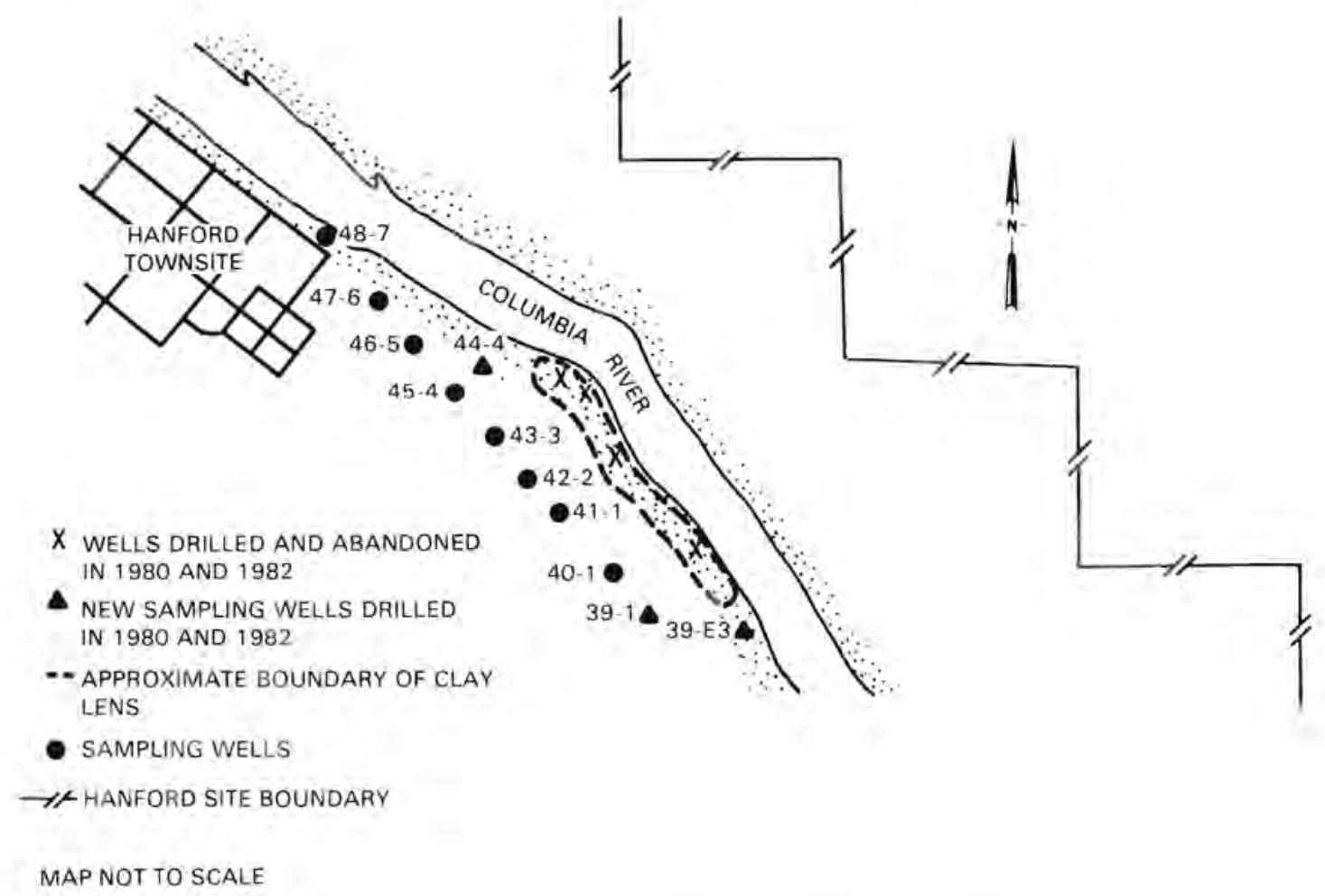

FIGURE 25. Locations of Selected Sampling Wells, Abandoned Wells, and the Clay Deposit 


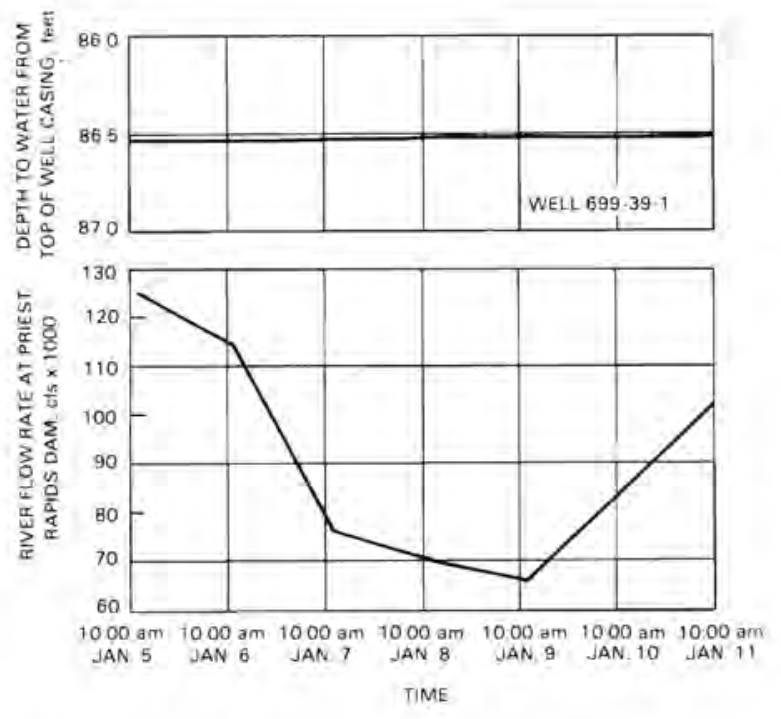

FIGURE 26. Changes in the Water Level in Well 69939-1 Compared with Changes in the Flow Rate of the Columbia River

trend is reversed when the river flow rate falls later in the year. The absence of this effect in wells west of the clay deposit is additional evidence that the deposit acts as a partial barrier to ground-water flow into the river.

\section{GEOPHYSICAL LOG INTERPRETATION}

Since 1958, the Ground-Water Surveillance Program has measured properties of the Hanford Site's subsurface through geophysical logging of the wells that have been drilled onsite. Geophysical logging basically consists of lowering sensory devices in a borehole and recording physical parameters that can be used to characterize the rocks, their contained fluids and the construction techniques used in the well (Keys and MacCary 1971). To date, nearly 800 wells have been logged (Blair, Law, and Lindberg, 1981). These logs constitute an important source of information on the subsurface environment at Hanford; however, until recently, no attempt had been made to consolidate the logging data and put them into a more useable form. In 1980, the Geophysical Log Interpretation task was established to meet these objectives. Under this task, a computerized data base system has been
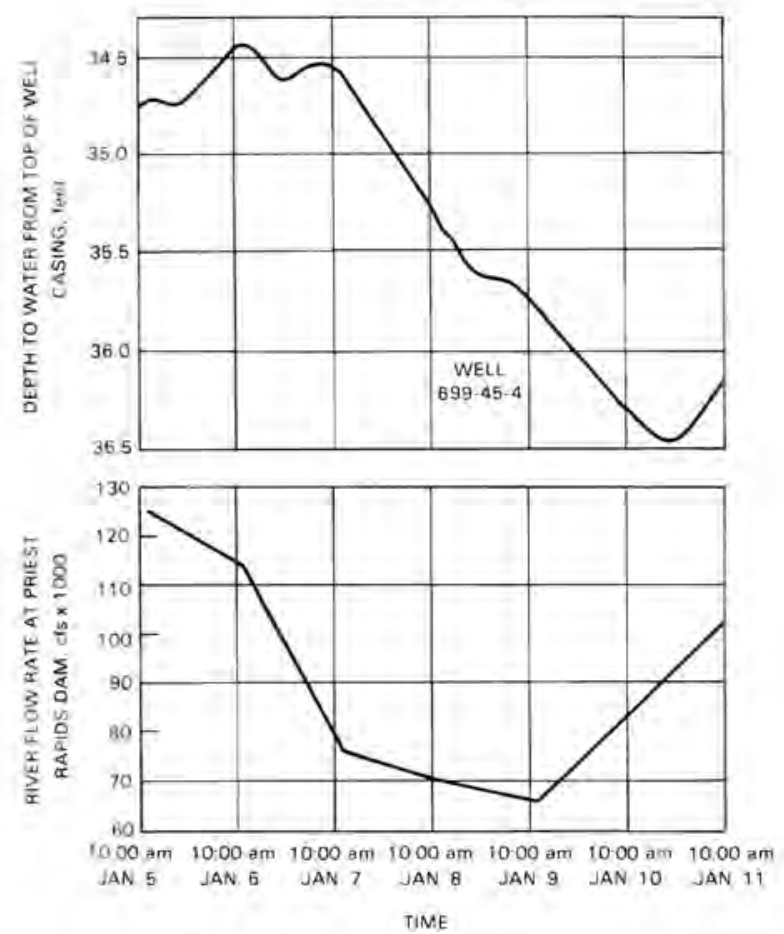

FIGURE 27. Changes in the Water Level in Well 69945-4 Compared with Changes in the Flow Rate of the Columbia River

developed for storing and retrieving the logging data (Petrie, Gibson, and Blair, 1983). In addition, a preliminary analysis of the logging data has been conducted. This analysis and its results are discussed in the following paragraphs.

The main objective of this preliminary statistical analysis was to study the variations between logs made on the same well on different days. This type of analysis can provide information on the relative accuracy of the data and can lead to identification of errors in data collection. In addition, it may indicate whether changes in the ground-water system with time can be detected using well log data.

The logs from Well 399-5-2 were the main source of information for this study because this well is used for calibration of the logging sondes and is therefore logged relatively often. Four log types were studied: temperature, natural gamma, neutron, and density. 

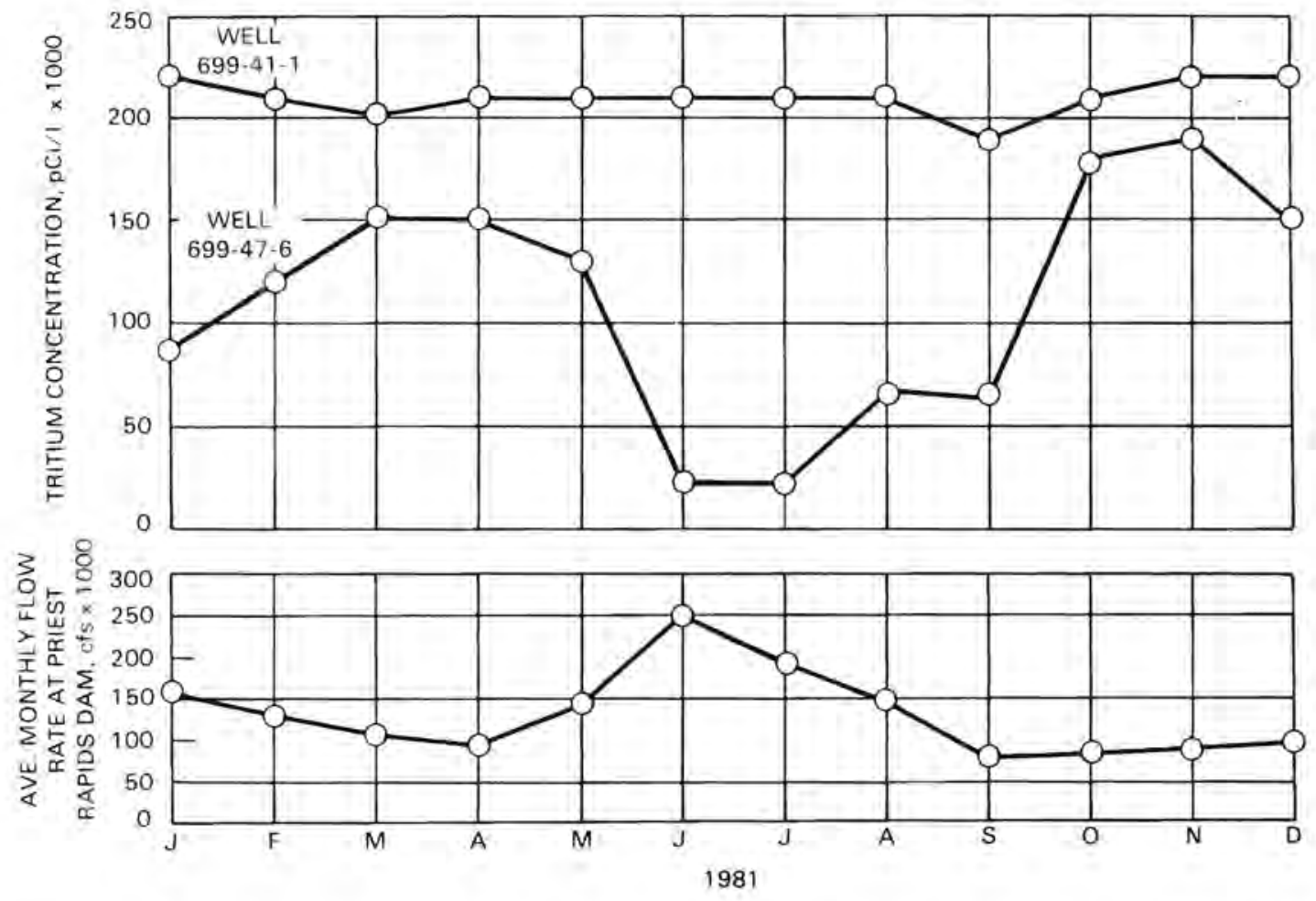

FIGURE 28. Changes in Tritium Concentrations in Wells 699-47-6 and 699-41-1 Compared with Changes in the Flow Rate of the Columbia River

Of the four log types studied, the analysis indicated that natural gamma is the most accurate measurement because the statistical variation in the gamma logs with time is smallest. This point is illustrated in Figure 29, which shows six natural gamma logs of Well 399-5-2 made at different times. The six curves are almost identical in shape. Although there is some displacement of the curves, it is statistically small. In contrast, the displacement and variation of the eight temperature logs shown in Figure 30 are statistically much greater. One possible explanation for the observed variation is simple human or instrument error; however, this explanation is not likely because the temperature gradient (i.e., the slope of the curve) is about the same for each log. Additional work is needed to determine the source of this unexpected complexity in the data. One conclusion drawn from this preliminary analysis is that an economical way to improve the quality of the data would be to achieve better equipment calibration.

\section{UPDATE OF INPUT DATA FOR THE VARIABLE THICKNESS TRANSIENT MODEL.}

The Variable Thickness Transient (VTT) model is used to predict the rate of ground-water flow in the unconfined aquifer at the Hanford Site. Two types of data used as input parameters for this digital model are aquifer transmissivities and aquifer bottom elevations. An update of the files containing these data was conducted during 1982. The results of this update, together with some background information on the data files, are discussed below.

\section{Aquifer Transmissivities}

Transmissivity is defined as the rate at which water is transmitted through a unit width of the aquifer under a unit hydraulic gradient. It is a property of both the aquifer and the contained fluid, and its value for a portion of an aquifer can be determined by a variety of techniques, including aquifer testing (Todd 1980). 


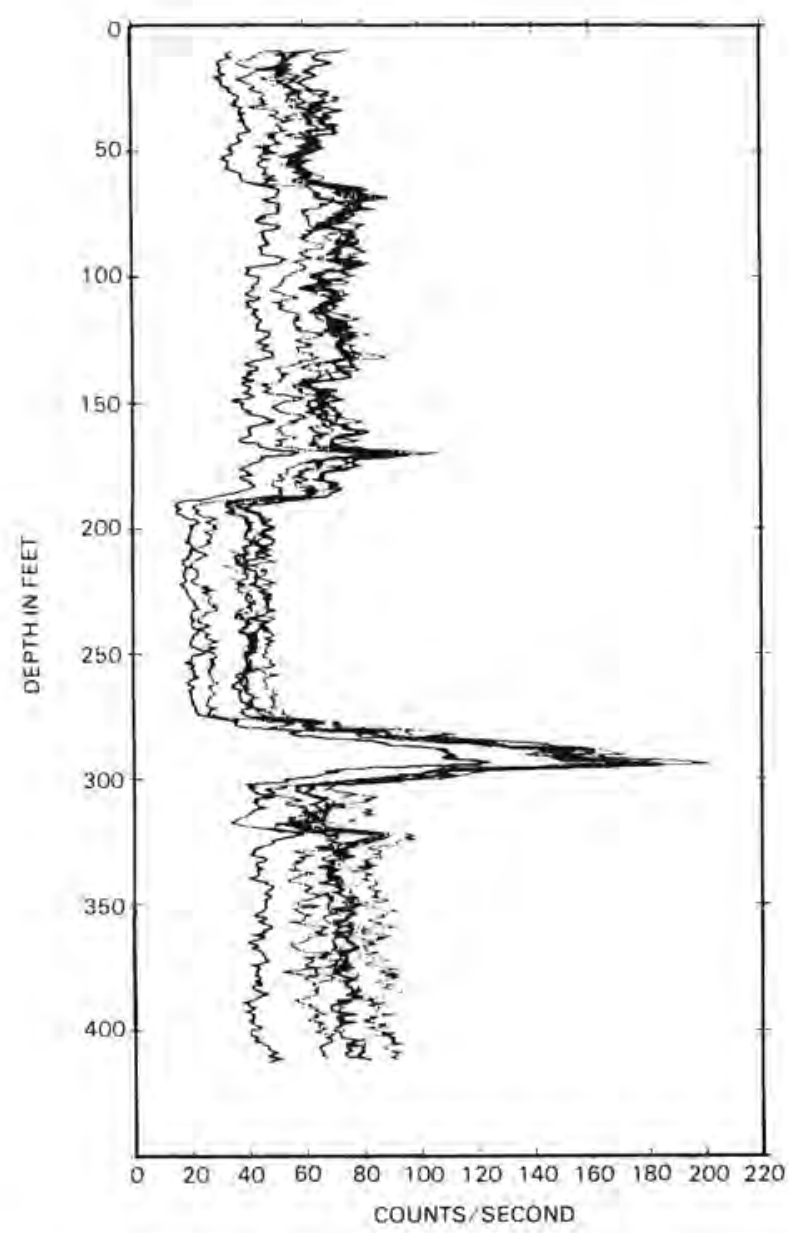

FIGURE 29. Six Natural Gamma Logs of Well 399-5-2

Aquifer transmissivities are needed as input for the Hanford VTT ground-water model. The model represents the transmissivity distribution in the unconfined aquifer with a matrix of values; each element of the matrix represents the transmissivity of the aquifer at a particular location on the Site. This matrix is updated periodically, taking into consideration the new transmissivity data derived from recent aquifer tests. When a discrepancy exists between a new transmissivity value derived from a recent test and the old value contained in the matrix, the test data and other pertinent information are examined to determine whether the value in the matrix should be changed. If the test results appear to be valid and are substantiated by other information, then the old value contained in the matrix is replaced by the new value.

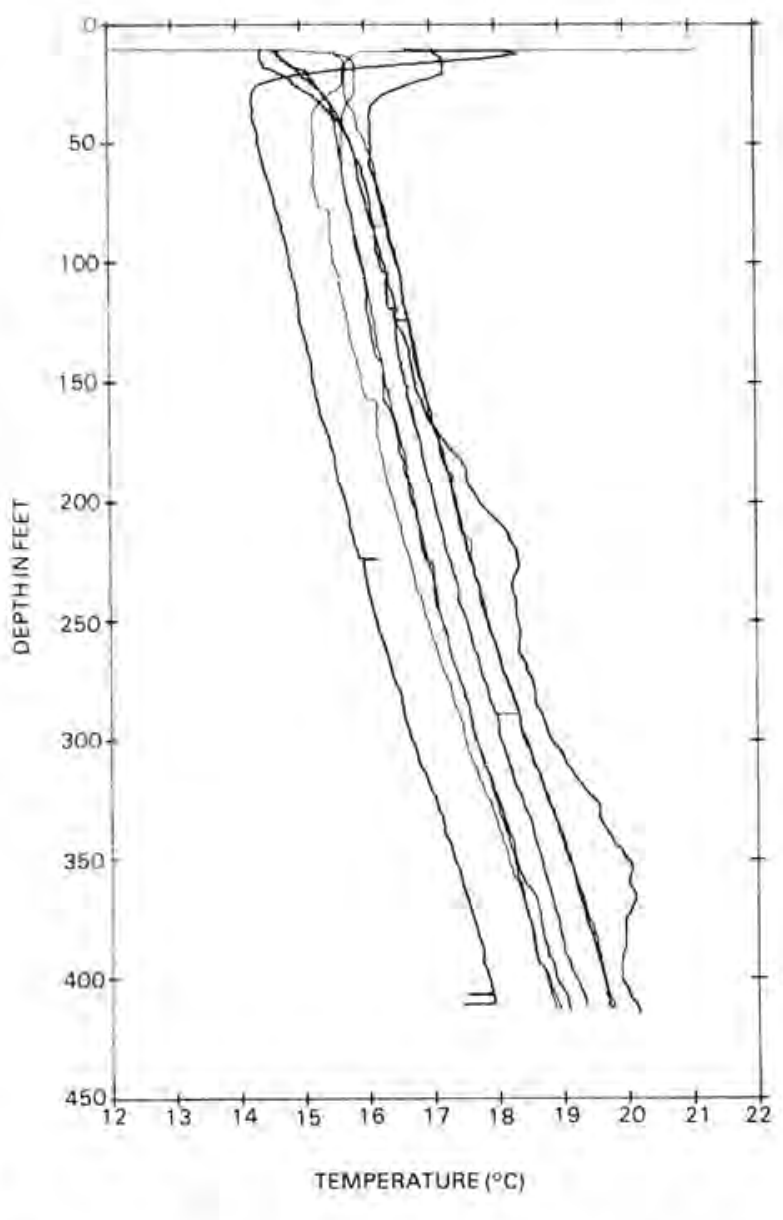

FIGURE 30. Eight Temperature Logs of Well 399-5-2

The most recent update of the Hanford transmissivity matrix was conducted in 1982 . Aquifer tests performed between 1973 and 1981 were included in the update. A total of 27 tests (of about eight hours duration or longer) were conducted on 25 wells during this period. Locations of these wells are shown in Figure 31. Using standard methods, transmissivity values were calculated from the test data. Values could not be calculated for two of the tests because of insufficient data. The values calculated for the remaining 25 tests were compared with the old values contained in the matrix. For 17 of the tests, the new and old values for transmissivity showed reasonable agreement.

For the other eight tests, the new and old values differed significantly. These eight tests were reexamined individually, relying on both the test 


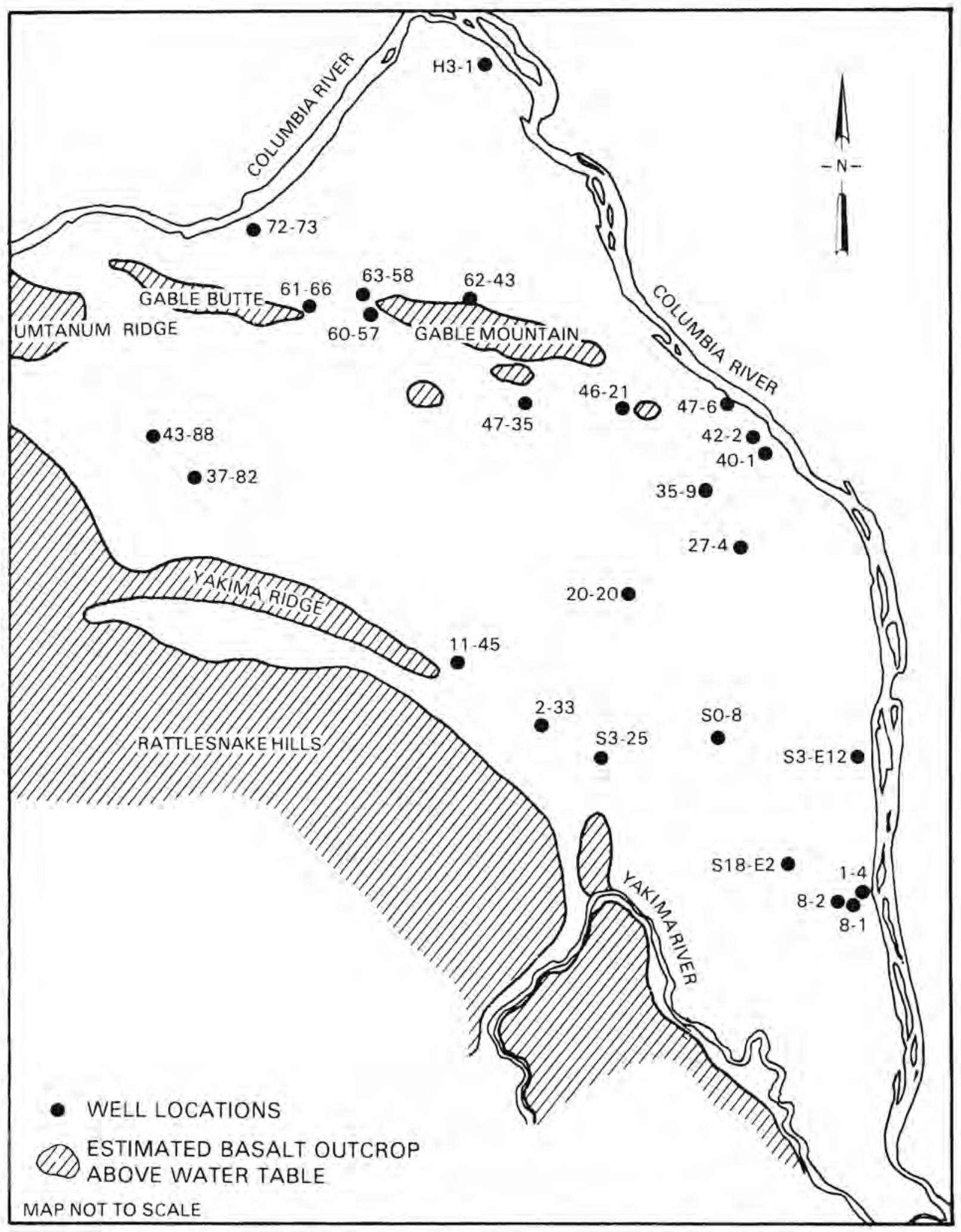

FIGURE 31. Locations of Wells Tested from 1973 to 1981 
data and other pertinent information such as special geological conditions or unusual circumstances connected with the test. Upon reexamination, only one of the eight tests (on Well 699-53-25) provided sufficient evidence to warrant changing the transmissivity value in the matrix. The net effect of the change was a lowering of the transmissivities in the area near this well. The original and revised transmissivity contours are shown in Figure 32.

\section{Aquifer Bottom Elevations}

The aquifer bottom elevations constitute important input data for the VTT model because the saturated thickness of the aquifer at a given location is determined by subtracting the aquifer bottom elevation from the water table elevation. The saturated thickness is then used in the calculation of hydraulic conductivity, which is a key parameter for hydrologic models.

Periodically, the file containing aquifer bottom elevations is updated, taking into consideration geological data obtained during the drilling of new wells. To update the file, driller's logs from new wells are examined for evidence of a relatively impermeable layer that can be interpreted as the aquifer bottom. The elevations obtained by this examination are then compared with the values in the data files. The well log is reexamined when the elevation estimated from a well log differs significantly (i.e., $>50 \mathrm{ft}$ ) from the elevation in the file. When the elevation estimated from the log is judged to be more correct than the elevation in the file, the logs of other nearby wells are examined for supporting evidence. If sufficient supporting evidence is found, the value in the file is changed.

In 180, an update of this file was conducted, focusing primarily on wells drilled near the Hanford Townsite. Over 100 geological logs were examined. This examination resulted in significant alterations of the aquifer bottom elevations, including the discovery of a previously unknown outcrop of basalt above the water table. The original and revised aquifer bottom contours are shown in Figure 33.

In 1982, a second update was conducted. Geological logs of nearly 150 wells drilled on the Site from 1973 to 1981 were examined. In several of these logs, there was an impermeable layer that could be the aquifer bottom at an elevation much different from that in the file. However, these were mainly isolated wells that lacked supporting evidence. Therefore, no changes were made to the file as a result of this update. 


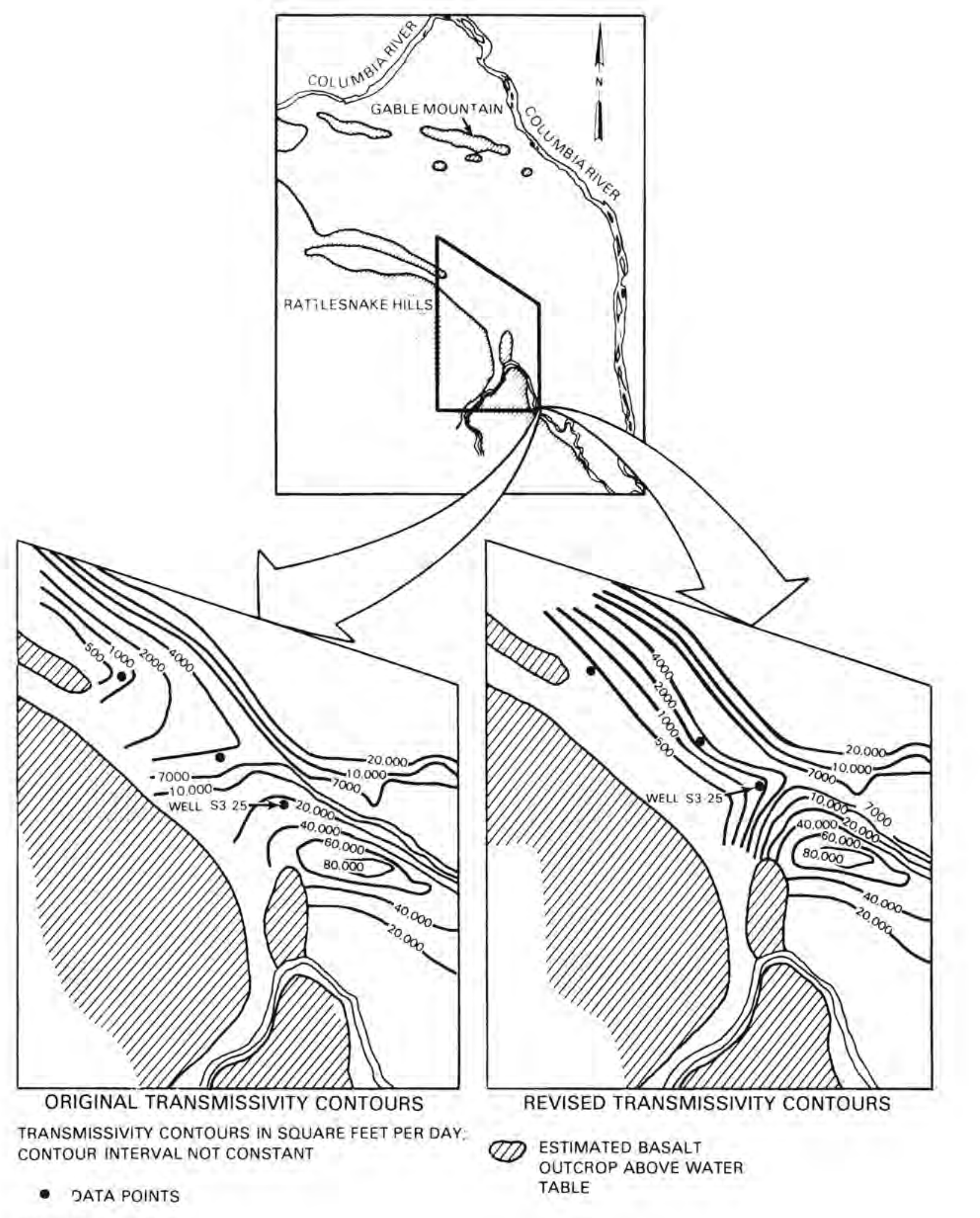

MAP NOT TO SCALE

FIGURE 32. Transmissivity Contours Before and After the 1982 Update 


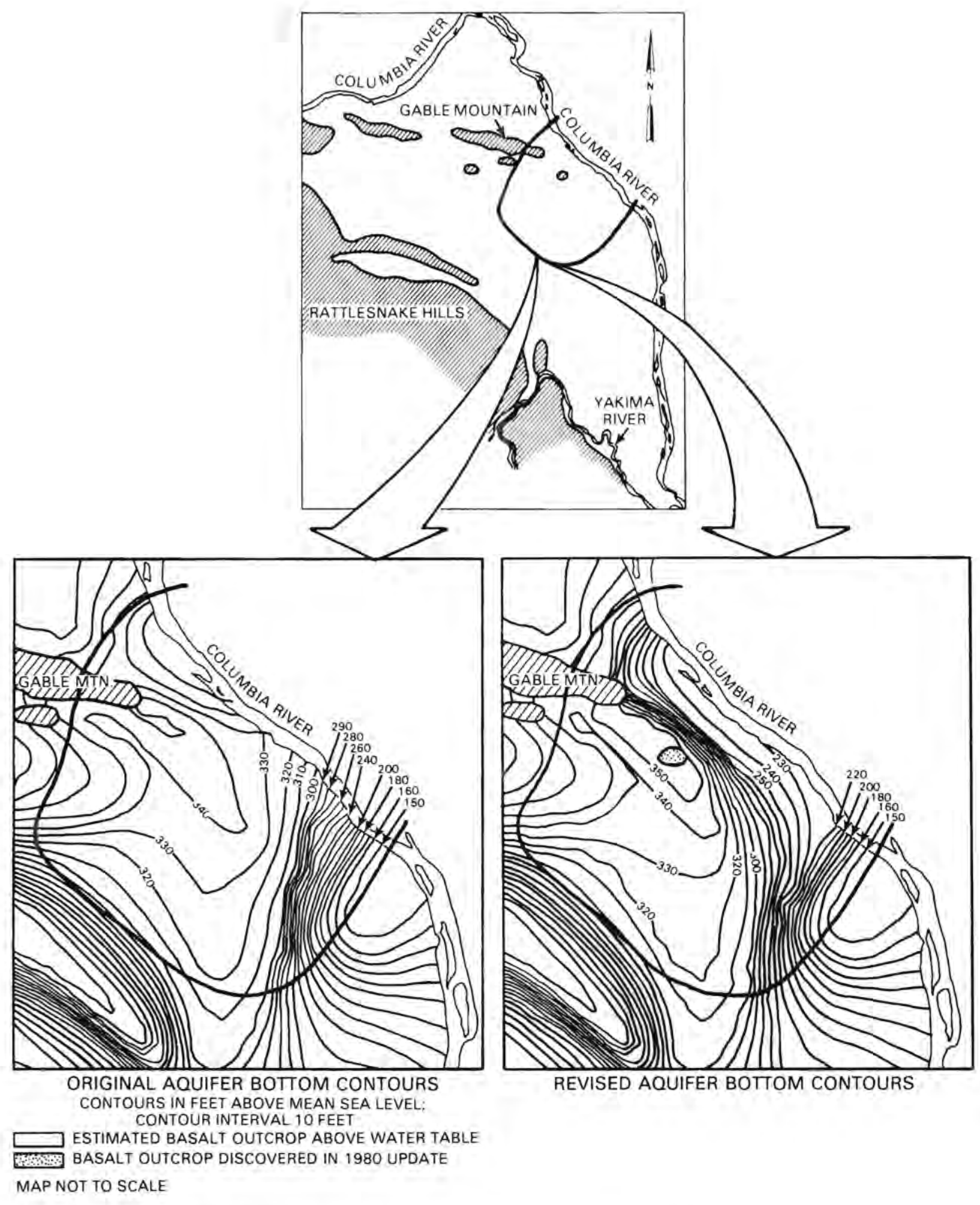

FIGURE 33. Aquifer Bottom Contours Before and After the 1980 Update 


\section{QUALITY CONTROL.}

The quality control effort of the Ground-Water Surveillance Program at PNL was initiated in 1974 and includes all phases of the program. Much effort is expended to ensure that samples are representative of the unconfined aquifer system beneath the Site. This includes: 1 ) well maintenance, 2) visual and geophysical inspection of wells, and 3) installation of sampling pumps. Blind and duplicate samples are analyzed at the PNL Technical Analysis Section to assure the quality of the analytical work. The U.S. Geological Survey, which also collects and analyzes ground water under a subcontract with PNL, has maintained a good quality assurance program. The quality control effort for the Ground-Water Surveillance Program shows that the data received are within the expected analytical limits of accuracy.

In addition to providing quality assurance, the U.S. Geological Survey provides data on the chemistry of Hanford ground water. These data, including wet chemical and spectrographic analysis, represent background information used in assessing the effects of plant operations. The results of the analyses made in 1982 are shown in Appendix C.

At the laboratory level the documentation of instrument calibrations and all procedures is required. Documentation of field instrument calibration has also been implemented. 


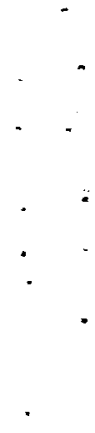

• 


\section{REFERENCES}

American Society for Testing and Materials (ASTM). 1979. 1979 Annual Book of ASTM Standards, Part 31: Water. American Society for Testing and Materials, Philadelphia, Pennsylvania.

Blair, S. C., L. S. Law, and J. W. Lindberg. 1981. A Catalog of Borehole Geophysics on the Hanford Site, 1958 to 1980. PNL-3504, Pacific Northwest Laboratory, Richland, Washington.

Blumer, P. J., M. J. Sula, and P. A. Eddy. 1981. Master Schedule for CY 1982 Hanford Environmental Surveillance Routine Program. PNL-4120, Pacific Northwest Laboratory, Richland, Washington.

Eddy, P. A., C. S. Cline, and L. S. Prater. 1982. Radiological Status of the Ground Water Beneath the Hanford Site, January-December 1981. PNL-4237, Pacific Northwest Laboratory, Richland, Washington.

Eddy, P. A., D. A. Myers, and J. R. Raymond. 1978. Vertical Contamination in the Unconfined Ground $W$ ater at the Hanford Site, Washington. PNL-2724, Pacific Northwest Laboratory, Richland, Washington.

Eddy, P. A., and J. S. Wilbur. 1981. Radiological Status of the Ground Water Beneath the Hanford Site, JanuaryDecember 1980. PNL-3768, Pacific Northwest Laboratory, Richland, Washington.

Gephart, R. E., et al. 1979. Hydrologic Studies Within the Columbia Plateau, Washington: An Integration of Current Knowledge. RHO-BWI-ST-5, National Technical Information Service, Springfield, Virginia.

Graham, M. J., et al. 1981. Hydrology of the Separations Area. RHO-ST-42, Rockwell Hanford Operations, Richland, Washington.

Greager, E. M. 1982. UNC Environmental Surveillance Report for the 100 Areas - FY 1982. UNI-2226, UNC Nuclear Industries, Richland, Washington.

Keys, W. S., and L. M. MacCary. 1971. Application of Borehole Geophysics to Water-Resources Investigations. Book 2, Chapter $E 1$ of Techniques of Water Resources Investigations of the United States Ceological Survey. U.S. Government Printing Office, Washington, D.C.

Maas, L. J. 1982. Hanford Sanitary Water Quality Surveillance, CY 1982. HEHF 39, Hanford Environmental Health Foundation, Richland, Washington.
McGhan, V. L., and D. W. Damschen. 1979. Hanford Wells. PNL-2894, Pacific Northwest Laboratory, Richland, Washington.

Myers, D. A. 1978. Environmental Monitoring Report on the Status of Ground Water Beneath the Hanford Site. PNL2624, Pacific Northwest Laboratory, Richland, Washington.

Newcomb, R. C., J. R. Strand, and F. J. Frank. 1972. Geology and Ground-Water Characteristics of the Hanford Reservation of the U.S. Atomic Energy Commission, Washington. Geological Survey Professional Paper 717, U.S. Government Printing Office, Washington, D.C.

Petrie, G. M., D. Gibson, and S. C. Blair. 1983. User's Manual for Geophysical Well Logging Software Programs. PNL-4562, Pacific Northwest Laboratory, Richland, Washington.

Sula, M. J., P. J. Blumer, and R. L. Dirkes. 1982. Environmental Status of the Hanford Site for CY 1981. PNL-4212, Pacific Northwest Laboratory, Richland, Washington.

Sula, M. J., et al. 1983. Environmental Surveillance at Hanford for CY 1982. PNL-4657, Pacific Northwest Laboratory, Richland, Washington.

Tallman, A. M., et al. 1979. Geology of the Separation Areas, Hanford Site, South-Central Washington. RHO-ST-23, Rockwell Hanford Operations, Richland, Washington.

Todd, D. K. 1980. Groundwater Hydrology. 2nd ed. John Wiley and Sons, New York, New York.

U.S. Department of Energy. 1981. "Requirements for Radiation Protection." In DOE Order 5480.1, Chapter XI. U.S. Department of Energy, Washington DC.

U.S. Geological Survey. 1983. Water Resources Data for Washington, Water Year 1982. U.S. Geological Survey Water Data Report WA-82-2, Tacoma, Washington.

Wilbur, J. S. 1983. Water Table Measurements: Data Maps - December 1982. Rockwell Hanford Operations, Richland, Washington.

Wilbur, J. S., and M. J. Graham. 1982. Results of the Separations Area Ground-Water Monitoring Network for 1981. RHO-HS-SR-5 P, Rockwell Hanford Operations, Richland, Washington. 



\section{APPENDIX A}

\section{TRITIUM AND NITRATE CONCENTRATIONS}

IN THE GROUND WATER

(UNCONFINED AQUIFER) 
NELL NO.

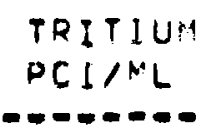

NITRATE

MG/L

\begin{tabular}{|c|c|c|c|c|c|}
\hline 1 & 03 & 1 & $\begin{array}{l}\text { MAX } \\
\text { AVE } \\
\text { MIV }\end{array}$ & $1.55 E+00 \star$ & $-0,-00$ \\
\hline 1 & $\$ 3$ & $2 P$ & $\begin{array}{l}M A X \\
A \cup E \\
M I P\end{array}$ & $<7.4 \cup E-01 *$ & $6.20 E-01 *$ \\
\hline 1 & 3 & $2:$ & $\begin{array}{l}\text { MAX } \\
\text { AVE } \\
\text { AIN }\end{array}$ & $<5.45 E-01 \star$ & $<5.00 E-n I$. \\
\hline 1 & 194 & 1 & $\begin{array}{l}\because \Delta x \\
A V E \\
m I N\end{array}$ & $\begin{array}{l}9.51) E+00 \\
3.40 E+00 \\
1.50 E+00\end{array}$ & $\begin{array}{l}9.00 E+110 \\
7.13 E+00 \\
4.80 \bar{E}+90\end{array}$ \\
\hline 1 & $n u$ & 2 & $\begin{array}{l}\operatorname{anx} \\
\operatorname{avt} \\
\operatorname{lin}\end{array}$ & $\begin{array}{l}2.111 E+00 \\
1.70 E+00 \\
1.20 E+00\end{array}$ & $\begin{array}{l}7 . \text { OUE +110 } \\
0.2 \cup E+00 \\
5.10 E+00\end{array}$ \\
\hline 1 & $\$ 4$ & 3 & $\begin{array}{l}\triangle A x \\
\Delta \cup t . \\
\therefore I\end{array}$ & $\begin{array}{l}0.8 \cup E+00 \\
3.10 E+00 \\
1.30 E+09\end{array}$ & $\begin{array}{l}9.30 E+00 \\
0.03 E+00 \\
5.10 E+10\end{array}$ \\
\hline 1 & Si: & 4 & $\begin{array}{l}\text { MAX } \\
\text { AVE } \\
\text { MIN }\end{array}$ & $1.706+00 *$ & $4.40 E+90 *$ \\
\hline 1 & 35 & 1 & $\begin{array}{l}\text { MAX } \\
\triangle V E \\
\text { MIN }\end{array}$ & $\begin{array}{l}? .00 E+00 \\
1.60 E+00 \\
0.40 E-01\end{array}$ & $\begin{array}{l}5.70 E+00 \\
4.40 E+00 \\
3.90 E+00\end{array}$ \\
\hline 1 & 29 & 1 & $\begin{array}{l}M A X \\
A V E \\
M I H\end{array}$ & $9.45 E-01$. & $0.05 E+00 \star$ \\
\hline 1 & 1) $?$ & 5 & $\begin{array}{l}M A X \\
A \cup F \\
\text { MI }\end{array}$ & $5.00 E+00 *$ & A. OOE + UI \\
\hline 1 & 05 & 12 & $\begin{array}{l}M A X \\
A V E \\
M I N\end{array}$ & $3.33 E+00 *$ & $1.69 E+01 *$ \\
\hline
\end{tabular}

מ- 3 values up less, no max uk min calculated 
NELL NO.

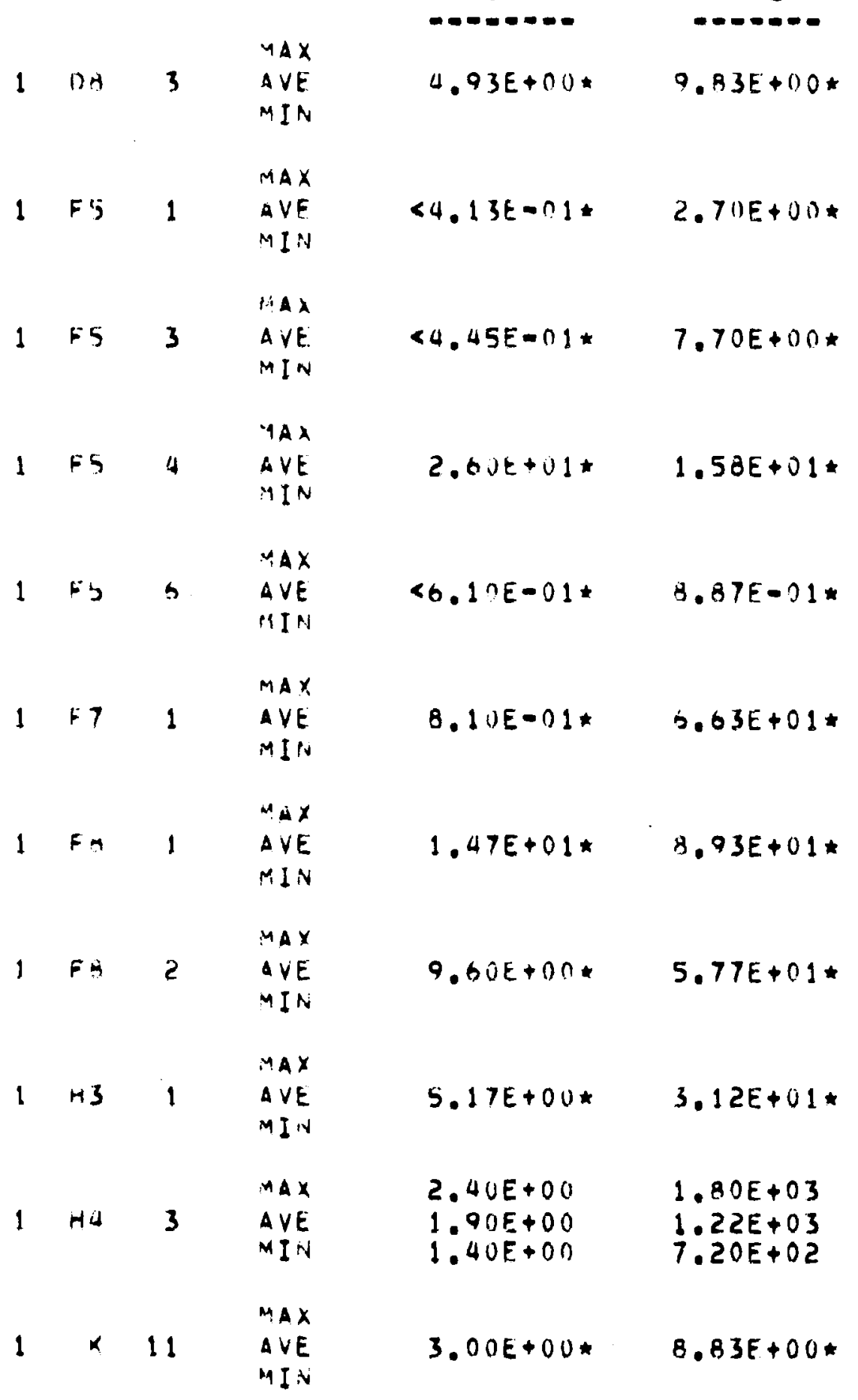

- - 3 values uR less, hu max or min calculateo

NITRATE

MG/L

TRITIUM

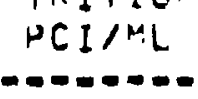




\begin{tabular}{|c|c|c|c|c|c|}
\hline \multicolumn{4}{|c|}{ WELL 10.} & TRITIUM & NITRATE \\
\hline 1 & $x$ & 19 & $\begin{array}{l}M A X \\
A V E \\
M I N\end{array}$ & $2.14 E+01 \star$ & $1.57 E+01 *$ \\
\hline 1 & $k$ & 20 & $\begin{array}{l}\text { IAX } \\
A \cup E \\
\text { MI I i }\end{array}$ & $1.11 E+00 \star$ & $3.80 E+00 *$ \\
\hline 1 & $n$ & 22 & $\begin{array}{l}A A X \\
A V E \\
A I N\end{array}$ & $1.01 E+00$ & $1.77 E+00 \star$ \\
\hline 1 & $x$ & 27 & $\begin{array}{l}M A Y \\
\text { AVE } \\
\text { HIV }\end{array}$ & $4.53 E+00$ & $1.93 E+00 *$ \\
\hline 1 & $x$ & 28 & $\begin{array}{l}X A X \\
A V E \\
\text { MIN }\end{array}$ & $3.43 E+00 *$ & $1.14 E+01 *$ \\
\hline 1 & $n$ & 29 & $\begin{array}{l}\text { PAX } \\
\text { AVE } \\
\text { MIV }\end{array}$ & $4.50 E+00 *$ & $<5.001 .01 *$ \\
\hline 1 & $k$ & 30 & $\begin{array}{l}\because A X \\
\triangle \vee E \\
\triangle I N\end{array}$ & H. BUE + OZ* & $1.80 E+91 *$ \\
\hline 1 & $\wedge$ & 2 & $\begin{array}{l}M A X \\
\Delta \cup E \\
A I N\end{array}$ & $3.25 E+01$ & $1.70 E+01 *$ \\
\hline 1 & $v$ & 3 & $\begin{array}{l}M A X \\
A V E \\
M I N\end{array}$ & $2.43 E+01 \star$ & \\
\hline 1 & iv & 4 & $\begin{array}{l}M A X \\
A \cup E \\
M I N\end{array}$ & $2.10 E+01 *$ & 1. $53 E+01 *$ \\
\hline 1 & A. & 5 & $\begin{array}{l}M A X \\
A Y E \\
M I N\end{array}$ & $2.41) E+01 *$ & $1.33 E+01 *$ \\
\hline
\end{tabular}

*-m 3 values ur less, ivo max or min calculateo 


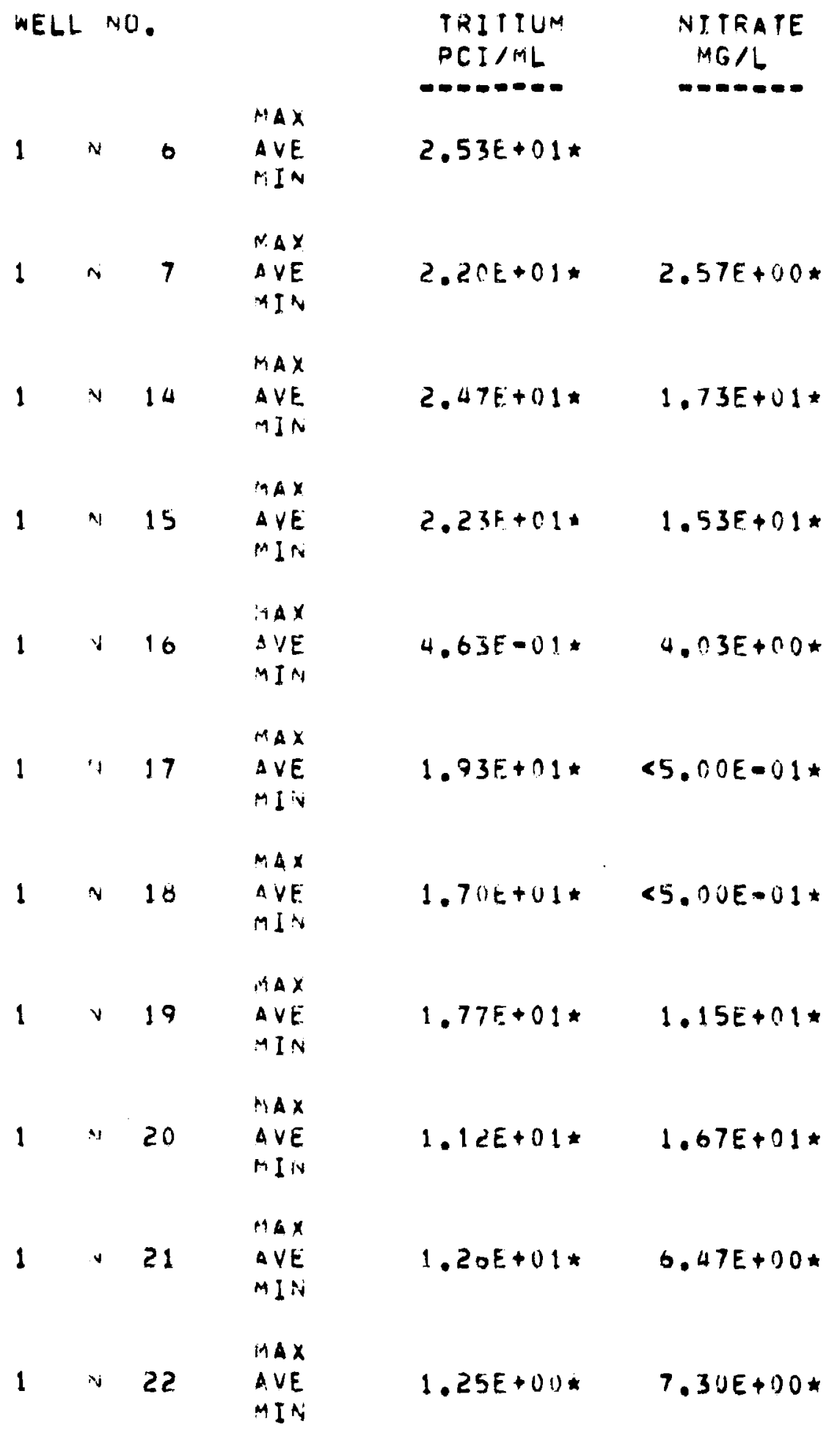

*- 3 VALUes or Less, iD MAX or min calculated 
NELL iN

\begin{tabular}{|c|c|c|c|c|c|}
\hline & $\begin{array}{l}P C 1 / 4 L \\
--0.0-0-\end{array}$ & \multirow{2}{*}{$\begin{array}{c}M 6 / L \\
4.37 E+00 \star\end{array}$} \\
\hline 1 & $v$ & 23 & $\begin{array}{l}\text { MAX } \\
A V E \\
M I N\end{array}$ & $1.12 E+00 *$ & \\
\hline 1 & is & 24 & $\begin{array}{l}\text { MAX } \\
\Delta V E \\
\text { MIN }\end{array}$ & $2.92 E+00 *$ & $0.77 E+00$. \\
\hline 1 & $\therefore$ & 25 & $\begin{array}{l}\text { MAX } \\
\text { AVE } \\
M I N\end{array}$ & $45.20 E-01 *$ & $1.40 E+01 \star$ \\
\hline 1 & v & $2 b$ & $\begin{array}{l}A A X \\
A Y E \\
A I N\end{array}$ & $<4.20 t=01 k$ & $1.40 E+01 *$ \\
\hline 2E & 19 & 1 & $\begin{array}{l}\text { MAX } \\
\text { AVE } \\
\text { MIN }\end{array}$ & $\begin{array}{l}<4.20 E-01 \\
<3.4 U E-01 \\
<3.00 E-01\end{array}$ & $\begin{array}{l}6.50 E-01 \\
0.76 E-01 \\
5.90 E-01\end{array}$ \\
\hline $2 E$ & 23 & 1 & $\begin{array}{l}\text { MAX } \\
\triangle \vee E \\
\text { MIIV }\end{array}$ & $\begin{array}{l}9.70 E+00 \\
8.93 E+00 \\
8.40 E+00\end{array}$ & $\begin{array}{l}1.40 E+01 \\
1.23 E+01 \\
1.10 F+01\end{array}$ \\
\hline $2 E$ & 21 & 7 & $\begin{array}{l}\text { MAX } \\
\triangle V E \\
\text { MIV }\end{array}$ & $\begin{array}{l}1.4 U E+00 \\
0.80 E-01 \\
5.60 E-101\end{array}$ & $\begin{array}{l}1.50 F+01 \\
1.08 E+01 \\
0.00 E+00\end{array}$ \\
\hline टE & 20 & 1 & $\begin{array}{l}M A X \\
A V E \\
\triangle I N\end{array}$ & $\begin{array}{l}<7.411 E-01 \\
<5.33 E=01 \\
<3.00 E-01\end{array}$ & $\begin{array}{l}<5.00 E-01 \\
<5.00 E-01 \\
<5.00 E-01\end{array}$ \\
\hline $2 E$ & 20 & 3 & $\begin{array}{l}M \triangle X \\
A \vee E \\
M I N\end{array}$ & $\begin{array}{l}1.60 E+01 \\
1.2+E+01 \\
9.60 E+00\end{array}$ & $\begin{array}{l}5.20 E+00 \\
4.03 E+00 \\
3.20 E+00\end{array}$ \\
\hline $2 E$ & 27 & 1 & $\begin{array}{l}M A X \\
\triangle V E \\
M I N\end{array}$ & $\begin{array}{l}1.5 \cap E+01 \\
9.40 E+00 \\
6.10 E-01\end{array}$ & $\begin{array}{l}8.50 E+0 J \\
6.33 E+00 \\
5.00 E+00\end{array}$ \\
\hline $2 E$ & $2 A$ & 1 & $\begin{array}{l}\text { MAX } \\
\text { AVE } \\
\text { YIN }\end{array}$ & $\begin{array}{l}1.40 E+01 \\
1.02 E+01 \\
4.80 E+00\end{array}$ & $\begin{array}{r}3.70 E+01 \\
1.67 E+01 \\
<5.00 E-01\end{array}$ \\
\hline
\end{tabular}




\begin{tabular}{|c|c|c|c|c|c|}
\hline \multicolumn{4}{|c|}{ WELL $N O$} & $\begin{array}{l}\text { THITIUM } \\
\text { PCIJIAL } \\
\text { PC-- }\end{array}$ & \multirow{2}{*}{$\begin{array}{c}\text { NITRATE } \\
\text { MG/L } \\
1.24 E+01 *\end{array}$} \\
\hline $2 E$ & 20 & 5 & $\begin{array}{l}M A X \\
A V E \\
M I N\end{array}$ & $<3.20 E-01 *$ & \\
\hline $2 E$ & 33 & 14 & $\begin{array}{l}\text { MAX } \\
\text { AVE } \\
\text { MIIS }\end{array}$ & $\begin{array}{l}<7.20 E=01 \\
<4.15 E=01 \\
<3.00 E=01\end{array}$ & $\begin{array}{l}3.40 E+01 \\
3.33 E+01 \\
3.30 E+101\end{array}$ \\
\hline $2 w$ & 6 & 1 & $\begin{array}{l}\text { MAX } \\
\text { AVE } \\
\text { MIN }\end{array}$ & $\begin{array}{l}3.70 E+01 \\
3.68 E+01 \\
3.60 E+01\end{array}$ & $\begin{array}{l}2.30 E+02 \\
1.44 E+02 \\
5.70 E+01\end{array}$ \\
\hline $2 w$ & 10 & 5 & $\begin{array}{l}\text { MAX } \\
\text { A VE } \\
\text { II } V\end{array}$ & $\begin{array}{l}2.10 E+01 \\
1.95 E+01 \\
1.30 E+01\end{array}$ & $\begin{array}{l}1.20 E+02 \\
7.33 E+01 \\
7.50 E+01\end{array}$ \\
\hline $2 w$ & 11 & 9 & $\begin{array}{l}\text { SAX } \\
\Delta V F \\
\text { MIN }\end{array}$ & $\begin{array}{l}1.8 U E+00 \\
1.44 E+110 \\
9.4 U E-01\end{array}$ & $\begin{array}{r}2.00 E+00 \\
9.78 E-01 \\
<5.00 E-01\end{array}$ \\
\hline $2 *$ & 12 & 1 & $\begin{array}{l}\text { MAX } \\
\text { AVE } \\
\text { MIN }\end{array}$ & $\begin{array}{r}1.50 E+00 \\
1.05 E+00 \\
<3.50 E-01\end{array}$ & $\begin{array}{l}2.00 E+02 \\
2.03 E+02 \\
8.20 F+01\end{array}$ \\
\hline $2 *$ & 18 & 3 & $\begin{array}{l}\text { MAX } \\
\text { A VE } \\
\text { MIN }\end{array}$ & $\begin{array}{l}<3.4 \cap E+01 \\
<9.01 E+00 \\
<5.30 E-01\end{array}$ & $\begin{array}{l}1.20 E+00 \\
1.10 E+00 \\
1.00 E+00\end{array}$ \\
\hline $2 w$ & 19 & 4 & $\begin{array}{l}Y A X \\
A V E \\
M I N\end{array}$ & $<5.80 E=01 *$ & $7.15 E+00 *$ \\
\hline $2 *$ & 21 & 1 & $\begin{array}{l}\text { MAX } \\
A V E \\
\text { IIN }\end{array}$ & $\begin{array}{l}\text { 1. } 1 \cup E+03 \\
0.8 \cup E+0 ? \\
3.3 \cup E+0 ?\end{array}$ & $\begin{array}{l}5.80 E+01 \\
5.35 E+01 \\
4.90 E+01\end{array}$ \\
\hline $2 w$ & 22 & 7 & $\begin{array}{l}\text { MAX } \\
A \cup E \\
\text { IIN }\end{array}$ & $\begin{array}{l}9.10 E+02 \\
7.80 E+02 \\
7.10 E+02\end{array}$ & $\begin{array}{l}<5.00 E-01 \\
<5.00 E-01 \\
<5.00 E-01\end{array}$ \\
\hline $2 \mathrm{in}$ & 22 & 9 & $\begin{array}{l}\text { MAX } \\
\text { IVE } \\
\text { IIN }\end{array}$ & $\begin{array}{l}1.10 E+01 \\
1.03 E+04 \\
1.00 E+0 \Delta\end{array}$ & $\begin{array}{l}<5,00 E-01 \\
<5.00 E-C 1 \\
<5.00 E-01\end{array}$ \\
\hline
\end{tabular}

*-o valjes ok less, ho max gr min calculateo 


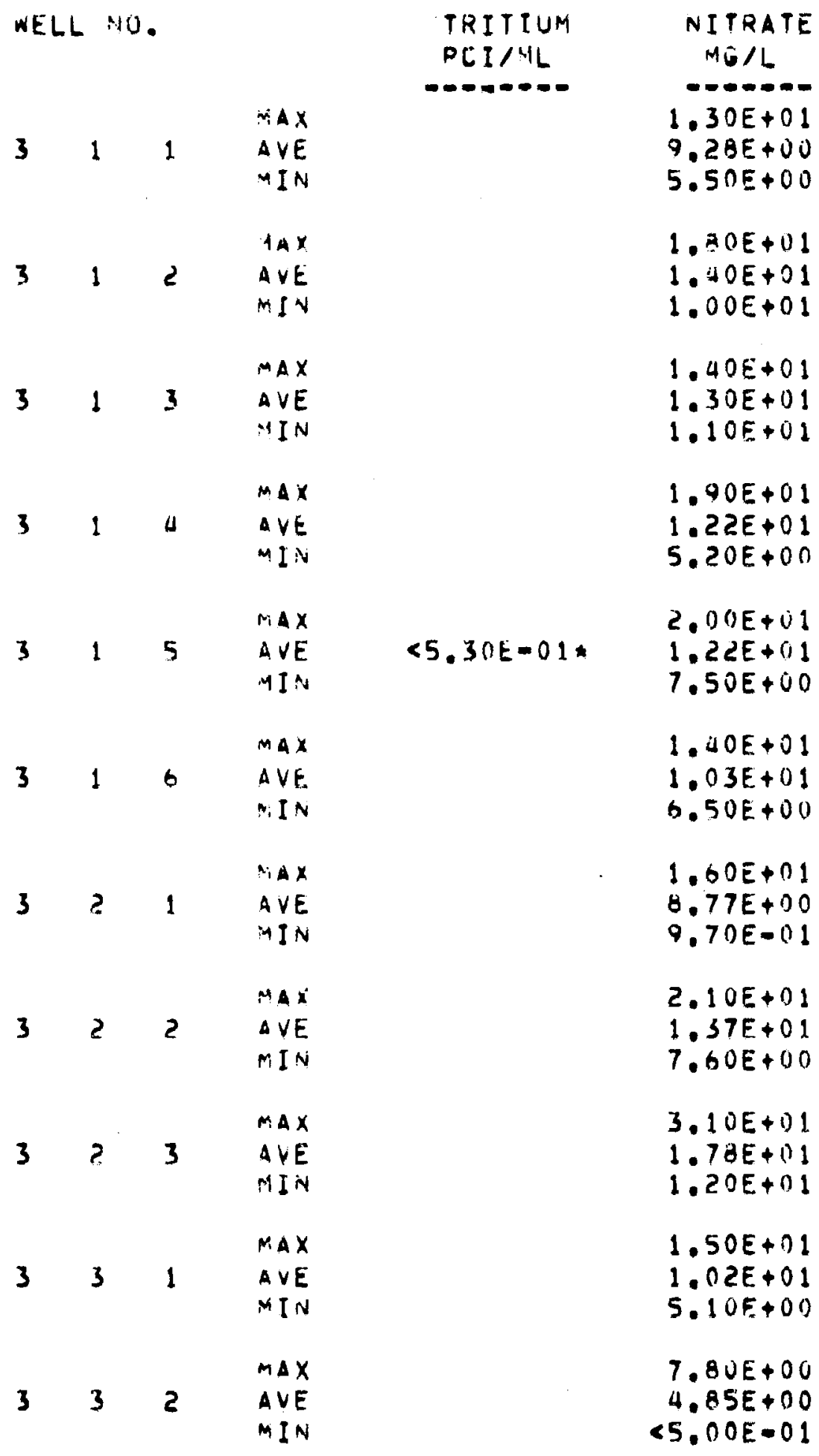

\#--3 VALUES OR LESS, No MaX oR MIN CALCULATEO 
WELL NU.

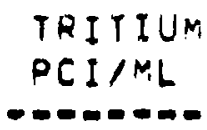

NITRATE

MG/L

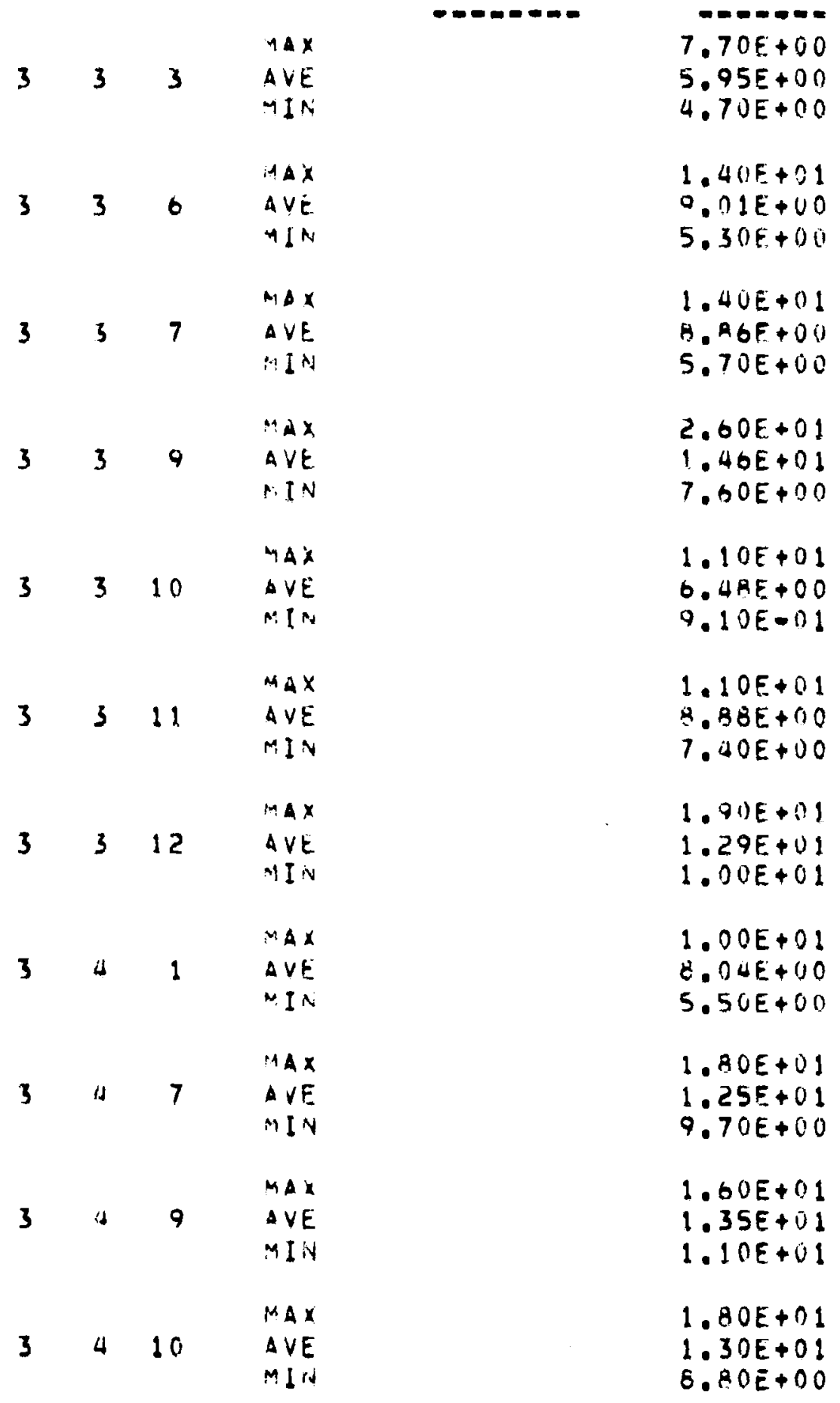

*-=-3 VALUES OR LESS, iW MAX OR MIN CALCULATED 


\begin{tabular}{|c|c|c|c|c|c|}
\hline We & LL $N$ & 10. & & TRITIUPA & NITEATE \\
\hline 3 & 5 & 1. & $\begin{array}{l}\text { MAX } \\
\text { AVE } \\
\text { MIIV }\end{array}$ & & $\begin{array}{l}2.00 E+01 \\
1.72 E+01 \\
1.50 E+01\end{array}$ \\
\hline 3 & 0 & 1 & $\begin{array}{l}\text { MAX } \\
\text { AVE } \\
\text { MIN }\end{array}$ & & $\begin{array}{l}1.50 E+01 \\
1.20 E+01 \\
6.90 E+00\end{array}$ \\
\hline 3 & 8 & 1 & $\begin{array}{l}\text { MAX } \\
\text { AVE } \\
\text { MIV }\end{array}$ & & $\begin{array}{l}0.00 E+00 \\
6.46 E+00 \\
5.30 E+00\end{array}$ \\
\hline 3 & 8 & 2 & $\begin{array}{l}\text { MAX } \\
A V E \\
M I V\end{array}$ & & $\begin{array}{l}9.40 E+00 \\
7.30 E+00 \\
5.20 E+00\end{array}$ \\
\hline 3 & 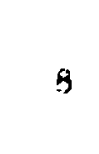 & 3 & $\begin{array}{l}\text { MAX } \\
\Delta V E \\
M I N\end{array}$ & & $\begin{array}{l}7.80 E+00 \\
0.64 E+00 \\
5.50 E+00\end{array}$ \\
\hline 3 & 9 & 4 & $\begin{array}{l}\text { MAX } \\
\text { AVE } \\
\text { MIN }\end{array}$ & & $\begin{array}{l}9.50 E+00 \\
4.28 E+100 \\
7.50 E+110\end{array}$ \\
\hline 6 & \$31 & IP & $\begin{array}{l}M A X \\
\text { AVE } \\
\text { YIN }\end{array}$ & $<4.27 E-01 \star$ & $1.18 E+00 *$ \\
\hline 0 & $S 30 E$ & 154 & $\begin{array}{l}\operatorname{MAx} \\
A \cup E \\
M I N\end{array}$ & & $\begin{array}{l}1.90 E+01 \\
1.53 E+01 \\
1.10 E+01\end{array}$ \\
\hline 6 & 529 & E12 & $\begin{array}{l}M A X \\
A V E \\
M I N\end{array}$ & & $\begin{array}{l}1.50 E+01 \\
1.18 E+01 \\
+.20 E+00\end{array}$ \\
\hline 6 & $\$ 27$ & E14 & $\begin{array}{l}\text { MAX } \\
\text { AVE } \\
\text { MIN }\end{array}$ & & $\begin{array}{l}1.90 E+01 \\
1.50 E+01 \\
0.80 E+00\end{array}$ \\
\hline 6 & 524 & 19 & $\begin{array}{l}\text { MAX } \\
\text { AVE } \\
\text { MIN }\end{array}$ & & $<5.005-01 \neq$ \\
\hline
\end{tabular}

*--3 VAlues or less, no max or min calculated 


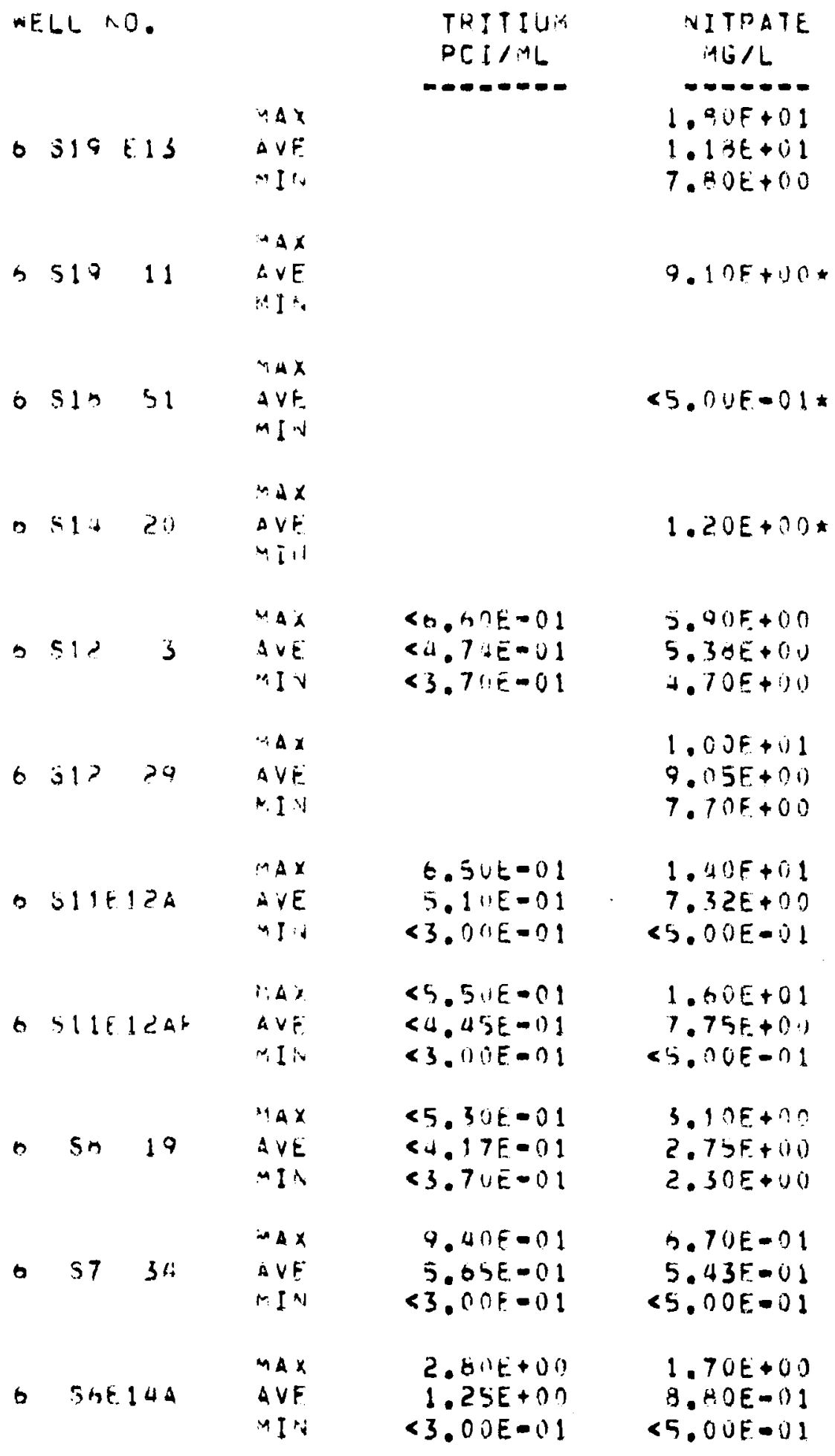

*-=3 values or less, yo max or min calculaten 
WELL NO.

TRITIUM

PCI/ML

MAX

6 So EUG AVE

MIS

- S6E4D

- S3E12

- $53 \quad 25$

$6517 t$

S Si) $B$

6 5) 7

$0 \quad 113$

623 MAX

$6233 A$

6345
MIA

$M A X$

MAX

$\triangle V E$

IIN

M $A X$

AVE

$M I$ IN

$\operatorname{mAX}$

$A \cup E$

MIN

$A \Delta X$

$A Y E$

MIN

MAX

AVE

$M I N$

$\operatorname{MAX}$

$A \vee E$

II A

$\operatorname{Mx}$

AVE

$M I N$

IAE

$A V E$

$M I N$

$M A X$

$A V E$

MIS
2. $\triangle D E+01$

2. $22 E+01$

2. $O J E+01$

3. 211E +01

3. $06 E+01$

$2.90 E+01$

1. $40 E+00$

$1.01 E+00$

$66.70 E-01$

$$
\text { 5. } 30 E-01
$$

$4.15 E-11$

$<3.70 E-01$

Q. $00 E+01$

$5.911 E+01$

$3.60 E+01$

5. $00 E+01$

2. $A 2 E+01$

2. $00 E+01$

5. $20 E+01$

$2.90 E+01$

2. OOE + U 1

Q. $20 E+01$

B. $85 E+01$

A. $3 \cap E+01$

$1.20 E+02$

1. $19 E+0 ?$

$1.1 O E+02$

(4. BUE-01

< . $19 E-U 1$

$<3.70 E=01$

$<4.25 E-01 *$
$6.23 E+00 *$

NITRATE

$M G / L$

$1.40 E+01$
$1.03 E+01$
$6.90 E+00$

$1.60 E+01$

1. $42 E+01$

1. $20 E+01$

1. $40 E+01$

$1.10 E+11$

B. $00 E+00$

C5. O0E-01

<5. OOE -01

$<5.00 E-01$

$6.70 E+00$

$1.76 E+00$

C5. OUE-U1

$4.5 O E+C O$

$2.20 E+00$

1. $20 E+00$

$2.10 E+01$

6. $12 E+00$

$<5,00 E-11$

2. $00 E+01$

$1.78 E+01$

$1.00 E+01$

$2.00 E+01$

2. $41 E+01$

$2.10 E+01$

1. $40 E+00$

8. $45 E-01$

<5. OOE-O1

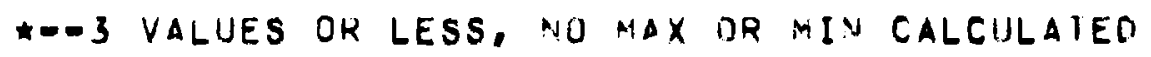




\begin{tabular}{|c|c|c|c|c|c|}
\hline \multicolumn{4}{|c|}{ WELL :O. } & \multirow{2}{*}{$\begin{array}{l}\text { TRITIUM } \\
\text { PCI/HL } \\
<-0.0-0-0 \\
<4.20 E=01 \\
<3.70 E=01 \\
<3.00 E-01\end{array}$} & \multirow{2}{*}{$\begin{array}{c}\text { NITRATE } \\
\text { MG/L } \\
.-0-0-0 \\
7.0 U E+00 \\
6.2 U E+00 \\
5.20 E+00\end{array}$} \\
\hline 6 & 4 & EO & $\begin{array}{l}M A X \\
A \cup E \\
M I N\end{array}$ & & \\
\hline 0 & 8 & 17 & $\begin{array}{l}\text { MAX } \\
\text { AVE } \\
\text { MIN }\end{array}$ & $\begin{array}{l}1.70 E+02 \\
1.65 E+0 ? \\
1.617 E+0 E\end{array}$ & $\begin{array}{l}2.70 E+01 \\
2.45 E+01 \\
1.90 E+01\end{array}$ \\
\hline 6 & 4 & 25 & $\begin{array}{l}M \triangle X \\
A V E \\
M I N\end{array}$ & $\begin{array}{l}7.00 E+01 \\
6.60 E+01 \\
6.40 E+01\end{array}$ & $\begin{array}{l}1.70 E+01 \\
1.56 E+01 \\
1.50 E+101\end{array}$ \\
\hline 6 & A & 32 & $\begin{array}{l}M A X \\
A V E \\
M I N\end{array}$ & $<4.53 E-01$ & $3.27 E+00 \star$ \\
\hline 6 & 9 & E2 & $\begin{array}{l}M A X \\
A \cup F \\
A I N\end{array}$ & $\begin{array}{l}<6.4 \cap E=01 \\
<5.20 E-01 \\
<3.70 E-01\end{array}$ & $\begin{array}{l}<5.00 E=01 \\
<5.0 D E-111 \\
<5.00 E-01\end{array}$ \\
\hline 6 & 10 & $E 12$ & $\begin{array}{l}\text { MAX } \\
\text { AVE } \\
M I N \text { V }\end{array}$ & $\begin{array}{l}3.40 E+01 \\
1.04 E+01 \\
1.20 E+0 ?\end{array}$ & $\begin{array}{l}1.70 E+01 \\
1.54 E+01 \\
1.40 E+01\end{array}$ \\
\hline 6 & 13 & $1 \mathrm{C}$ & $\begin{array}{l}\text { MAX } \\
\text { AVE } \\
\text { MIN }\end{array}$ & $\begin{array}{l}<6.50 E=01 \\
<4.73 E=01 \\
<3.00 E=01\end{array}$ & $\begin{array}{l}<5.00 E-01 \\
<5.00 E-01 \\
<5.00 E-01\end{array}$ \\
\hline 6 & 13 & 64 & $\begin{array}{l}\text { MAX } \\
\text { AVE } \\
\text { MI IS }\end{array}$ & $\begin{array}{l}\angle 7.00 E=01 \\
<5.25 E-01 \\
<3.00 E-01\end{array}$ & $\begin{array}{r}1.10 E+00 \\
7.00 E=01 \\
\times 5.00 E-01\end{array}$ \\
\hline 6 & 14 & $E B P$ & $\begin{array}{l}\text { Max } \\
\text { AvE } \\
\text { MIN }\end{array}$ & $<4.00 E-01 *$ & $<5.00 F=01 *$ \\
\hline 6 & 14 & EOT & $\begin{array}{l}M A X \\
A V E \\
M I I S\end{array}$ & $2.47 E+01 \ldots$ & $9.23 E+00 \star$ \\
\hline 6 & 14 & 38 & $\begin{array}{l}\text { MAX } \\
\text { AVE } \\
\text { MIN }\end{array}$ & $\begin{array}{l}<5.00 E-01 \\
<3.93 E-01 \\
<3.00 E-01\end{array}$ & $\begin{array}{l}1.8 O E+00 \\
1.68 E+00 \\
1.50 E+00\end{array}$ \\
\hline
\end{tabular}

\#--3 values ur less. no max or min calculateo 


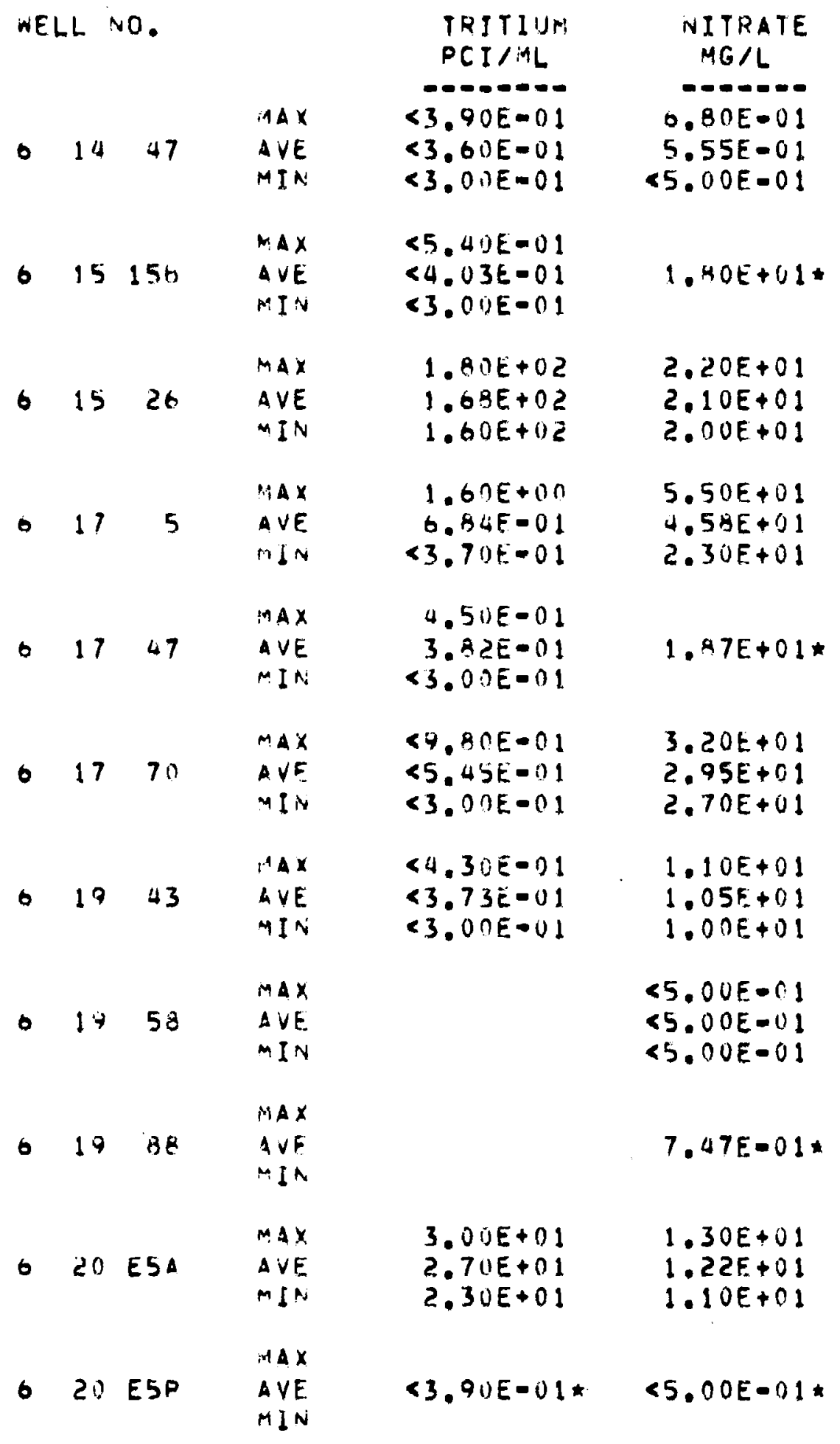

*--3 values uR less. no max or min calculated 
WELL NO.

TRITIUA

PCI I:HL

NITRATE

$M G / L$

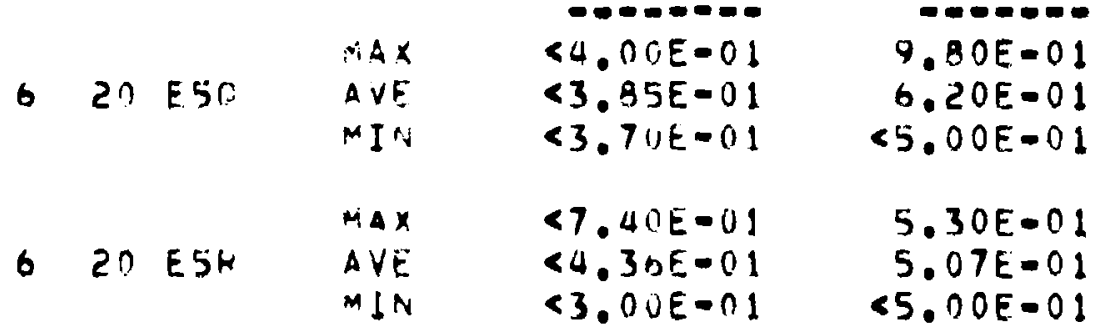

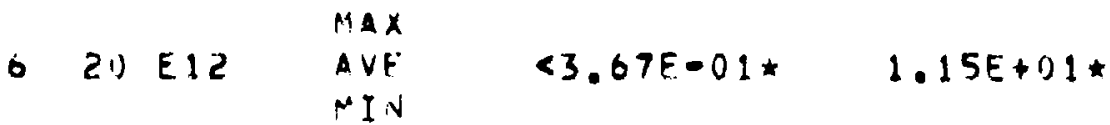

$\begin{array}{rlll}\text { MAX } & <4.4 J E-01 & <5.00 E-01 \\ \text { AVE } & <3.75 E-01 & <5.00 E-01 \\ M I N & <3.00 E-01 & <5.00 E-01\end{array}$

$62020 \quad \begin{aligned} & \Delta V E \\ & \Delta I N\end{aligned} \quad 4.43 E+02 \star \quad 4.07 E+01 *$

$\begin{array}{rrrr} & & 2.70 E+00 & <5.00 E=01 \\ M V E & 9.70 E-01 & <5.00 E-01 \\ M I N & <3.00 E-01 & <5.00 E-01\end{array}$

$\begin{array}{lllll} & M A X & <8.00 E-01 & 1.50 E+01 \\ & \quad 20 \text { AVE } & <5.85 E-01 & 1.43 E+01\end{array}$

$\begin{array}{lllll}M A X & <7.60 E-01 & 8.20 E+00 \\ 62270 \quad \triangle V E & <4.50 E-01 & 7.45 E+00 \\ M I N & <3.00 E-01 & 5.80 E+00\end{array}$

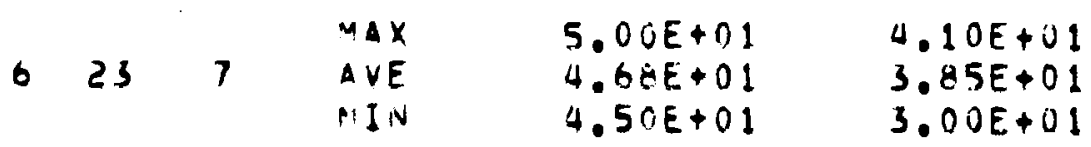

$\begin{array}{rlll} & \text { MAX } & <4.8 O E-01 & <5.00 E-01 \\ M I N E & <4.05 E-01 & <5.00 E-01 \\ & <3.70 E-01 & 55.00 E-01\end{array}$

$\begin{array}{rlrr}M A X & <7.10 E-01 & 5.60 E-01 \\ \text { AVE } & <4.30 E-01 & 5.12 E-01 \\ M I N & <3.00 E-01 & 55.00 E-01\end{array}$

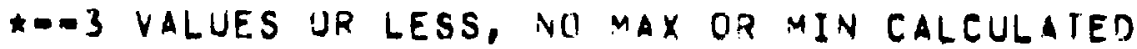


WELL NO.

$6201 \mathrm{H}$

$N A X$

AYE

MIN

$6 \quad 24 \quad 15$

$624 \quad 1 T$

$6 \quad 2+33$

$624 \quad 46$

$6 \quad 25 \quad 55$

- 2570

62615

- $26 \quad 89$

$6 \quad 27 \quad 4$

$6 \quad 27 \quad 8$

$\operatorname{Ax}$

$\triangle Y V E$

MIN

MAX

AVE

MIN

$M A X$

AVE

MIN

$\operatorname{MAX}$

$A \cup E$.

IN

$\operatorname{AAX}$

AVE

MIN

MAX

$\triangle V E$

MIN

$M A X$

$\triangle V E$

MIN

$M A X$

AVE

NIN

$M A X$

AVE

HIV

$M A X$

AVE
THITIU:

PCI/ML

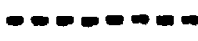

Q4. 20E-01

<3.72E-01

<3. OUE-01

NIN

<5. 1OE-01

<3.90E-01

<3. ONE-0 1

$5.80 E+00$

$5.50 E+00$

5. $20 E+00$

D. $10 E+01$

$5.53 \hat{E}+01$

5. $2 \cap E+01$

<7. $1(1 E-1) 1$

$<4.45 E=01$

C3. OUE-01

< $7.00 E-01$

$<4.611 E=01$

$<3.00 E-01$

$0.00 E+02$

5. BSE +02

$5.50 E+0 Z$

8. $80 E+01$

$6.19 E+01$

3. 3 UE + OA

$7.10 E+02$

$0.9 n E+02$

$6.80 E+02$

NITRATE

MG/L

$-0-0-0$

$45.00 E-01$

< $5.00 E-01$

$<5.00 E-01$

$7.30 E-01$

5.78E-01

$\angle 5.00 E-01$

5.90E-01

$5.10 E-01$

$<5.00 E-01$

$1.60 E+01$

$1.53 E+01$

1. $40 E+01$

<5. OUE-OL

$<5.00 E_{-11}$

$<5 . \cap \cup E-01$

$1.10 E+C 1$

1. $.02 E+01$

$8.10 E+00$

$1.30 E+00 * \quad 1.20 E+01 *$

4. $00 E+01$

$3.78 E+112$

$3.30 E+01$

$1.90 E+00 \star$

$2.70 E+01$

$2.18 E+01$

$1.60 E+01$

$4.8 \cup E+01$

$4.60 E+01$

$4.20 E+01$

\#--3 values uR less, ho max or min! calculateo 
NELL NO.

TRITIUM

NITRATE

PCI/PIL

$4 G / L$

$\begin{array}{llll}\text { MAX } & 1.80 E+01 & 1.00 E+01 \\ \text { MIN } 28 \text { MIN } & 1.36 E+01 & 8.40 E+00 \\ & 9.30 E+U 0 & 7.20 E+00\end{array}$

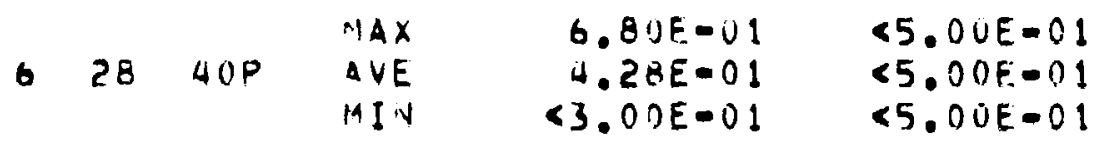

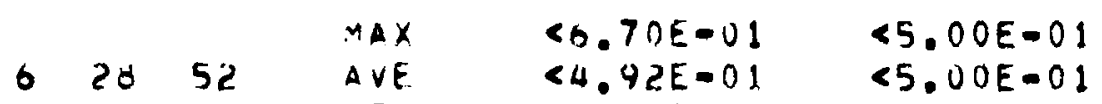

MIN $\quad 3.0 \cap F-01 \quad \angle 5.00 E-01$

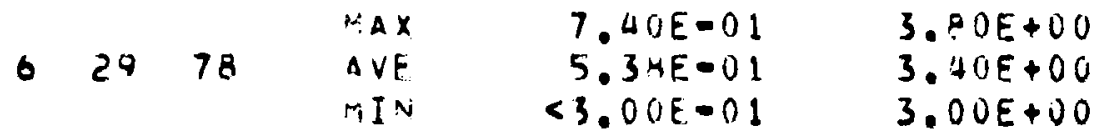

63131 AVE $2.99 E+02$ 2.35E+01

HIN 2.7กE+02 2.20E+01

$\begin{array}{rrr}\text { MAX } & 2.60 E+02 & 1.30 E+00 \\ \text { AVE } & 5.24 E+01 & 0.92 E=01 \\ M I N & <3.00 E-01 & 5.00 E=01\end{array}$

631538 AVE $\quad 3.00 E-01 * \quad 3.70 E+00 *$

$\begin{array}{llll} & \text { inAX } & 0.80 E+02 & 5.10 E+01 \\ \text { - } 32 \text { LVE } & 3.3 H E+02 & 4.00 E+01 \\ M I N & 7.90 E+02 & 1.40 E+01\end{array}$

6 32. 42 MVE $\quad 2.45 E+02 * \quad<5.00 E-01 *$

$\begin{array}{llll} & M A X & 3.00 E+01 & 1.40 E+01 \\ \text { AVE } & 2.65 E+01 & 1.30 E+01 \\ \text { MIN } & 2.30 E+01 & 1.20 E+01\end{array}$

63262 MVE $\operatorname{MIN}(5.2) E-01 * \quad 2.50 E+01 *$

*--3 VALUES UR Less, ivo maX OR min calculateu 
MELL NO.

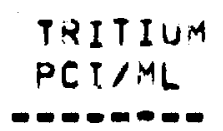

\section{NITRATE}

HG/L

M MAX

- 3270 AVE

MIN

$2.63 E+02 \star$

1. $23 E+11 *$

$M A X$

6 32 77 AVE

MIN

$1.04 E+00 *$

$4.33 E+00 *$

$6 \quad 3342$

$M A X$

AVE

MIN

1. $20 E+02$

$1.02 E+02$

$2.00 E+01$

B. $90 E+01$

1. $60 \mathrm{U}+01$

$1.30 E+01$

b 3350

$M x$

$A V E$

MIN

$<3.8 \cap E-01 *$

$7.03 E+00 *$

MAX

$\triangle V E$

$1.90 E+02$

1.7BE+02

$1.0 D E+U 2$

$1.90 E+01$

$1.78 E+01$

$4 I N$

$1.60 E+01$

$634 \quad 41$

SAX

$1.70 E+02$

$2.10 E+01$

$1.05 E+02$

$1.35 E+01$

MIN

$1.50 E+02$

1. $70 E+01$

$6 \quad 34 \quad 42$

$A A X$

AVE

MIN

$1.57 E+02 *$

$2.59 E+01 *$

63451

tax

$\triangle V E$

<6.7 JE $=01$

<4.92E-01

<3. OUE-OI

$7.00 E+00$

MIN

$5.76 E+00$

$4.50 E+00$

6 3is 86 AVE

C6. 5UE-01

1. $50 E+01$

C5.18E-01

1. $28 E+01$

$M I N$

<3. ODE-OL

$1.10 E+01$

6359

$\operatorname{AAX}$

1. $4 C E+02$

$2.30 E+01$

$\triangle V E$

1. $2 D E+0$ ?

$1.96 E+01$

MIN

1. $20 E+02$

1. $.00 E+01$

$6 \begin{array}{r}\text { MAX } \\ \text { AVE } \\ \text { MIN }\end{array}$

1. $03 E+03 \pi$

$2.10 E+01 *$

*-o-3 values or less, no max or min calculateo 


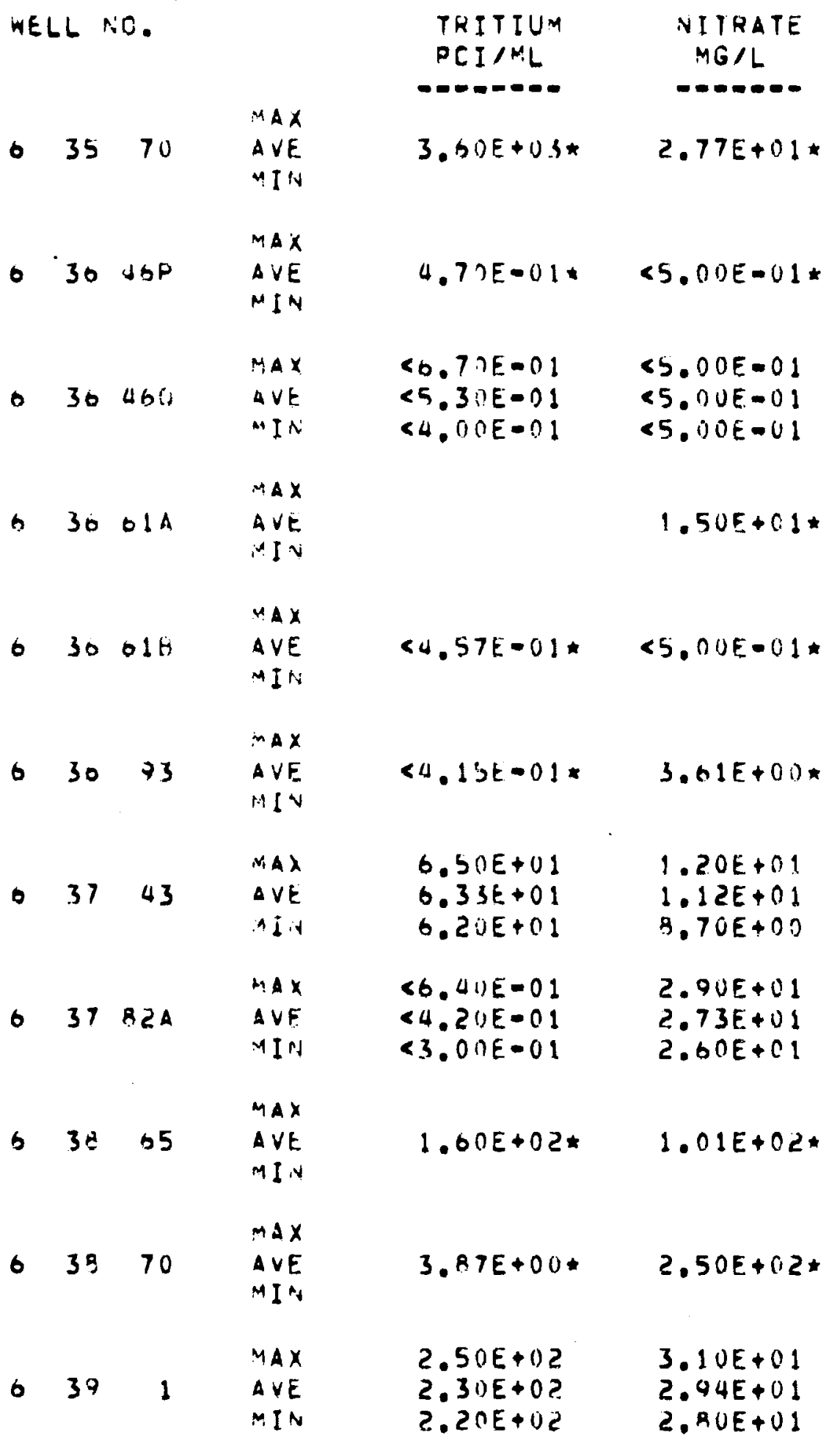

*--3 values ok less, nu max uk min calculateo 
WELL NO.

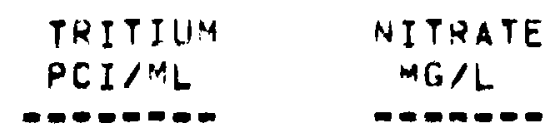

\begin{tabular}{|c|c|c|c|c|c|}
\hline & & & & & \\
\hline 6 & 39 & 39 & $\begin{array}{l}M A X \\
A V E \\
M I N\end{array}$ & $<4.95 E-01 \star$ & $\angle 5.00 E-01 \star$ \\
\hline 6 & 39 & 79 & $\begin{array}{l}\text { MAX } \\
\text { AVE. } \\
\text { MIN }\end{array}$ & $\begin{array}{r}n .90 E+00 \\
2.13 E+00 \\
<3.00 E-01\end{array}$ & $\begin{array}{r}9.80 E-01 \\
8.03 E=01 \\
<5.00 E=01\end{array}$ \\
\hline 6 & 40 & 1 & $\begin{array}{l}M A X \\
A V E \\
M I N\end{array}$ & $\begin{array}{l}\text { 2. } 30 E+0 ? \\
\text { 2. } 2 \text { KE+02 } \\
\text { ?. } 20 E+02\end{array}$ & $\begin{array}{l}3.20 E+01 \\
3.03 E+01 \\
2.90 E+01\end{array}$ \\
\hline 6 & $4 n$ & 334 & $\begin{array}{l}\text { MAX } \\
A V E \\
\text { MIN }\end{array}$ & $<5.25 E-01 *$ & $<5.00 E-01 \star$ \\
\hline 6 & 40 & 62 & $\begin{array}{l}\text { MAX } \\
A V E \\
M I P .\end{array}$ & $1.43 E+01 *$ & $2.00 E+01 *$ \\
\hline 6 & 41 & 1 & $\begin{array}{l}\text { MAX } \\
\text { AVE } \\
\text { MiN }\end{array}$ & $\begin{array}{l}2.30 E+02 \\
\text { ?. } 22 E+02 \\
\text { 2. } 00 E+02\end{array}$ & $\begin{array}{l}3.20 E+01 \\
2.96 E+01 \\
2.80 E+01\end{array}$ \\
\hline 6 & 41 & 23 & $\begin{array}{l}\text { MAX } \\
\text { AVE } \\
\text { MIN }\end{array}$ & $\begin{array}{l}5.30 E+02 \\
5.16 E+02 \\
4.80 E+02\end{array}$ & $\begin{array}{l}3.20 E+01 \\
2.92 E+01 \\
2.70 E+01\end{array}$ \\
\hline 6 & 42 & 2 & $\begin{array}{l}\text { MAX } \\
\text { AVE } \\
\text { MIN }\end{array}$ & $\begin{array}{l}2.20 E+02 \\
1.98 E+02 \\
1.90 E+02\end{array}$ & $\begin{array}{l}3.00 E+01 \\
2.91 E+01 \\
2.70 E+01\end{array}$ \\
\hline 6 & 42 & $12 A$ & $\begin{array}{l}\text { AAX } \\
A V E \\
M I N\end{array}$ & $\begin{array}{l}3.40 E+02 \\
3.25 E+02 \\
3.20 E+02\end{array}$ & $\begin{array}{l}3.30 E+01 \\
3.10 E+01 \\
3.10 E+01\end{array}$ \\
\hline 6 & 43 & 3 & $\begin{array}{l}A A X \\
A \cup E \\
M I N\end{array}$ & $\begin{array}{l}2.30 E+02 \\
1.85 E+02 \\
1.20 E+02\end{array}$ & $\begin{array}{l}2.90 E+01 \\
2.43 E+01 \\
1.60 E+01\end{array}$ \\
\hline 6 & 43 & 88 & $\begin{array}{l}M A X \\
A V E \\
M] A N\end{array}$ & $\begin{array}{l}<9.20 E-01 \\
<5.84 E-01 \\
<3.00 E=01\end{array}$ & $\begin{array}{l}2.30 E+00 \\
1.36 E+00 \\
0.20 E=01\end{array}$ \\
\hline
\end{tabular}

- - 3 values or less, no max or min calculateo 
WELL INO.

$\begin{array}{ll}\text { AVE } & 1.40 E+02 \\ M I N & 1.10 E+02\end{array}$

$\begin{array}{ll}\text { AVE } & 1.40 E+02 \\ M I N & 1.10 E+02\end{array}$

$M A X$

61464

A VE

MI A

$645 \quad 4$

$M x$

$\triangle V E$

MIN

$M A X$

b 4542

$A \vee \varepsilon$

MIN

$\Delta A X$

$6415 \quad 69$

$A V E$

MIN

6 16 4

MAX

AVE

MIN

640 M AVE

Iis

$6 \quad 46 \quad 21$

A $A X$

$\triangle Y E$

PI IN

MAX

6476

$\triangle V E$

MIN

$\sin$

AVE

MIN

$M A X$

64746
AVE

NIV
TRITIUM

PCI/NL

1.0-0.0-0.

1.9.1.E+02

NITRATE $M G / L$

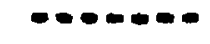

$2.70 E+01$

$2.16 E+01$

1. $70 E+01$

<4.65E-01* 2.10E+11.

1. $10 E+102$

$1.90 E+01$

$9.17 E+00$

$<5.00 E-01$

Q. $10 E+01$

3. $B O E+100$

1. IUE +0 ?

$1.03 E+02$

$9.2 \cup E+01$

$3.30 E+00$

2. $20 F+i 0$

$5.27 E-01 *$

$2.10 E+01=$

$7.60 t+01 k$

$9.30 E-01 *$

$2.30 E+02$

2. $00 E+01$

$1.75 E+02$

2. $05 E+01$

1. $30 E+02$

1. $60 E+11$

$3.50 E+01$

1. $30 E+01$

$3.3 \times F+01$

1. $08 E+01$

3. $2 \| E+01$

$7.10 E+00$

$1.90 E+02$

2. $20 E+01$

$1.32 E+01$

1. $40 E+00$

$7.60)+00$

$5.00 E+00$

2. $53 E+00$

< . I HE-01

$<5.00 E-01$

$<3.00 E-01$

$<4.73 E-01$.

B. $57 E+00 *$

*--3 VALUES UK LESS, IVI MAX UK MIN CALCULATED 
WELL ND.

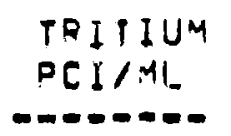

NITRATE

MG/L

\begin{tabular}{|c|c|c|c|c|c|}
\hline$b$ & 47 & 60 & $\begin{array}{l}\text { MAX } \\
\text { AVE } \\
\text { MIN }\end{array}$ & $<3.83 E-01 \star$ & $1.43 E+01 *$ \\
\hline 6 & $\Delta B$ & 7 & $\begin{array}{l}4 A X \\
A V E \\
\text { IIN }\end{array}$ & $3.20 E+00=$ & $4.20 E+00 *$ \\
\hline 6 & $4 i$ & 18 & $\begin{array}{l}M \Delta X \\
Q V E \\
M I N\end{array}$ & $\begin{array}{l}<5.00 E-U 1 \\
<3.98 E-U 1 \\
<3.00 E-01\end{array}$ & $\begin{array}{l}5.50 E+00 \\
3.70 E+00 \\
1.00 E+00\end{array}$ \\
\hline 6 & 40 & 11 & $\begin{array}{l}\text { AAX } \\
\text { MVE } \\
M I N\end{array}$ & $<4.37 E-01 *$ & $2.00 E+01 *$ \\
\hline 0 & 49 & 13 & $\begin{array}{l}\text { MAX } \\
\triangle V E \\
\text { WIN }\end{array}$ & $\begin{array}{r}3.70 E-01 \\
6.43 E-01 \\
<3.00 E-01\end{array}$ & $\begin{array}{l}3.80 E+00 \\
3.67 E+00 \\
3.00 E+00\end{array}$ \\
\hline 6 & 49 & 20 & $\begin{array}{l}M A X \\
A \cup E \\
M I N\end{array}$ & $\begin{array}{l}<6.12 E-01 \\
<4.3 O E-01 \\
<3.00 E-11\end{array}$ & $\begin{array}{l}<5.00 E-01 \\
<5.00 E-01 \\
<5.00 E-01\end{array}$ \\
\hline 6 & 49 & 55 & $\begin{array}{l}\text { MAX } \\
\text { A VE } \\
\text { MIIS }\end{array}$ & $<6.93 E-01 \star$ & $2.13 E+00$ \\
\hline 6 & 47 & 57 & $\begin{array}{l}M A X \\
A \cup E \\
M I N\end{array}$ & $3.43 E+01 \hbar$ & $2.03 E+02 \star$ \\
\hline 6 & 49 & 79 & $\begin{array}{l}\text { MAX } \\
\text { AVE } \\
\text { MIV }\end{array}$ & $<\Delta .03 E-01 *$ & $3.60 E+01 *$ \\
\hline 6 & 50 & 288 & $\begin{array}{l}\text { PAX } \\
A V E \\
M I N\end{array}$ & $\begin{array}{l}<7.30 E-01 \\
<5.5 \cup E-01 \\
<3.00 E-01\end{array}$ & $\begin{array}{r}1.60 E+00 \\
1.20 E+00 \\
<5.00 E-01\end{array}$ \\
\hline 6 & So & 30 & $\begin{array}{l}\text { MAX } \\
A V E \\
M I N\end{array}$ & $\begin{array}{l}<4.70 E-01 \\
<3.78 E-01 \\
<3.00 E-01\end{array}$ & $\begin{array}{r}5.20 E-01 \\
5.05 E-01 \\
<5.00 E-01\end{array}$ \\
\hline
\end{tabular}

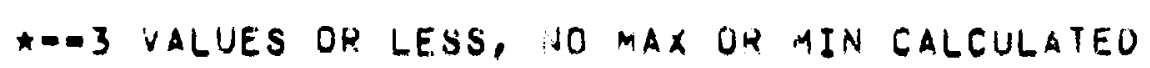


WELL NO.

TKITIUM

PCI/tiL

NITRATE

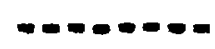

MG/L

$\begin{array}{rlrr} & \text { MAX } & 2.10 E+00 & 5.20 E-01 \\ \text { AVE } & 1.73 E+00 & 5.05 E-01 \\ & \text { MIN } & 1.20 E+00 & 5.00 E-01\end{array}$

$65053 \quad$ AVE $\quad 5.97 E-01 * \quad 9.70 E+00 *$

mint

AVE $\quad 4.63 E-01 * \quad 1.80 E+01$ *

YIN

$\operatorname{AAX}$

- 5163 AVE

YIN

$<4.53 E-01 * \quad 5.33 E+00 *$

65175

$\operatorname{in} \Delta x$

$A \vee E$

MIN

$<4.27 E-01 *$

$9.67 E=01 *$

$M A X$

$6 \quad 53 \quad 35$

$\triangle V E$

$M I$ IV

$<4.60 E-01$

$<3.95 E-01$

<3. $00 E-01$

$<5.00 E-01$

$\operatorname{Ax}$

<6. $40 E=1) 1$

$<4.07 E-111$

$\angle 3$. SUE $=01$

$\angle 5$. UVE-OI

$<5.00 E-01$

- 53103

$\triangle V E$

MIV

<5. OOE-01

<5, OUE $=01$

$<5.00 E-01$

MI S

$2.75 E+00 *$

S4 $34 \quad M \quad$ MVE
AVE

SD. OUE-01

$<4.2 N E-01$

Q.2UE-01

MIV

$<3.00 E-01$

$0.35 E-01$

$<5.00 E-01$

$6 \quad 54 \quad 374$

$A: A X$

$\triangle Y E$

$(5.50 E=01$

<5. $00 E-01$

$M T N$

Q $4.43 E-01$

<5.00E-01

<3.0DE-OI

C5. $00 E=01$

MIAX
$0 \quad 54$ 4? AVE

II IN

<4.25E-01*

$1.12 E+00 *$

t=-3 values or less, ho max or in calcillated 
WELL NO.

$M I N$

$\operatorname{MA} X$

65457 AVE.

YIN!

6 s5 21

$655 \quad 40$

- $55 \quad 44$

- $5550 \mathrm{~A}$

655506

- 55500

6 is 70

65370

- $55 \quad 89$
$M A X$

$A \vee E$

MIN

$\sin x$

$\Delta V E$

IIN

$\sin x$

I I

$M x$

i $\vee \mathrm{E}$

III

$M d X$

$\triangle V E$

MIN

$4 i x$

a VE.

iIN

$\sin x$

AVE

AIn

$\because 4 x$

$\triangle V E$

II I

$M A X$

$\triangle V E$

IIN
TRITIUM

PCI/ML

C.

$<7.22 E-01$

$<4.70 E-01$

$<3.0$ OE-O1

NITRATE

$M G / L$

- - - - - =

3. $80 E+00$

2. $10 E+00$

C5. OOE-O1

$<5.33 t-01+$

$6.10 E-01 *$

$47.90 E-01 *$

3. BOE+00*

<8.20E- 01

<. $00 E=01$

$<4.5 E-01$

<5. OOE =01

$63.0 O E-01$

$<5 . \cap O F=01$

$<3.10 E-01 \quad 5.00 E-01$

$<4.9 ! E-01$

<5. OUE-OI

$<3.71) E=01$

\& . DOE-01

$<A .00 E-01$

$<5.00 E-01$

$<5.53 E=01$

$<5.00 F-01$

<3.70E-01

$<5.00 E-01$

$<5.27 E-01 * \quad<5.00 E=01 *$

<6. OOE $=01$

<4.7EE-01

$<3.91 E=01$

$6.20 E-01$

$5.50 E-01$

$<5.00 E-01$

$<4.10 E-01 * \quad<5.00 E-01 *$

$<5.00 E-01 \star$

$1.60 E+00 *$ 


\begin{tabular}{|c|c|c|c|c|c|}
\hline & $-L N$ & 0. & & TRITIUM & NITR:ATE \\
\hline 6 & 50 & 43 & $\begin{array}{l}M A X \\
A V E \\
\text { SIIA }\end{array}$ & $\begin{array}{l}<7.00 E=01 \\
<4.5 .5 E-01 \\
<3.0 \cap E-01\end{array}$ & $\begin{array}{r}5.20 E-01 \\
5.05 E-01 \\
<5.00 E-1) !\end{array}$ \\
\hline 6 & 57 & $25 \mathrm{~A}$ & $\begin{array}{l}M A X \\
A V E \\
M I N\end{array}$ & $<5.87 E-U 1 *$ & $1.00 E+00 *$ \\
\hline 0 & 57 & 29 & $\begin{array}{l}\text { MAX } \\
\text { AVE } \\
\text { BIIN }\end{array}$ & $6.53 E-31+$ & $9.77 E=01 *$ \\
\hline 6 & 57 & 33 & $\begin{array}{l}\text { MAX } \\
\text { AVE. } \\
\text { MIN }\end{array}$ & & $\begin{array}{l}2.00 F+00 \\
1.37 E+00 \\
0.80 F-01\end{array}$ \\
\hline 0 & 55 & 24 & $\begin{array}{l}\operatorname{MAx} \\
\text { Avf } \\
\text { MIV }\end{array}$ & $<5.00 E-01 *$ & $1.93 E+00+$ \\
\hline 0 & 54 & 32 & $\begin{array}{l}\text { MAX } \\
\text { AVE } \\
\text { III IV }\end{array}$ & $1.22 E+011 *$ & $1.10 E+00$ \\
\hline 0 & 57 & 58 & $\begin{array}{l}\text { MAX } \\
\text { AVE } \\
\text { MIN }\end{array}$ & $1.87 E+00$ & $0.57 E-n 1 *$ \\
\hline 6 & 54 & $80 B$ & $\begin{array}{l}A \Delta X \\
A \cup E \\
A I P I\end{array}$ & & $\angle 5.00 E=01 *$ \\
\hline b & 00 & 32 & $\begin{array}{l}\text { MAX } \\
\text { AVF } \\
\text { MIN }\end{array}$ & $1.37 E+00 *$ & $2.33 E+00 \star$ \\
\hline 6 & so & 57 & $\begin{array}{l}\text { YAX } \\
\text { AVE } \\
\text { MIN }\end{array}$ & $9.6) E-01 t$ & $<5,00 E=01 *$ \\
\hline 6 & 60 & 60 & $\begin{array}{l}\because A X \\
A V E \\
N I A\end{array}$ & $1.37 E+00$ & $9.60 E=01 \star$ \\
\hline
\end{tabular}

*om 3 val.ues un less, io rax or min calculateo 
NELL 90.
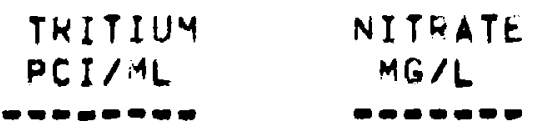

$\begin{array}{lll}\text { NIAX } & \\ \text { DVE } & \text { MIN } & 1.40 E+00 \text { * }\end{array}$

\begin{tabular}{|c|c|c|c|c|c|}
\hline 6 & 61 & 41 & $\begin{array}{l}\text { MAX } \\
A V E \\
M I N\end{array}$ & $<4.47 E-01 *$ & $8.53 E-111 *$ \\
\hline 8 & of & 62 & $\begin{array}{l}\text { MAX } \\
\text { AVE } \\
M I A S\end{array}$ & $8.10 E+00 \star$ & $\begin{array}{l}7.50 E+00 \\
3.61 E+00 \\
5.50 E-01\end{array}$ \\
\hline & 62 & 31 & $\begin{array}{l}\text { IAX } \\
\text { AVE } \\
\text { MIIV }\end{array}$ & & $3.27 E+00 *$ \\
\hline & $b 2$ & $43 F$ & $\begin{array}{l}a \Delta x \\
\Delta v E \\
M I r_{i}\end{array}$ & 1. $32 E+U 0 *$ & $3.57 E-01 \star$ \\
\hline & 03 & $25 A$ & $\begin{array}{l}\text { MAX } \\
\text { AVE } \\
\text { MIN }\end{array}$ & $<4.83 E-01 \star$ & $9.00 E+00$ \\
\hline
\end{tabular}

6 S3 51 MVE $\begin{aligned} & \text { AVX } \\ & \text { MIN }\end{aligned} \quad 4.15 E-01 *<5.00 E-01 *$

66355 AVE

60358 MVE $\begin{aligned} & M A X \\ & M I V\end{aligned} \quad 7.70 E-01 * \quad 1.13 E+00 *$

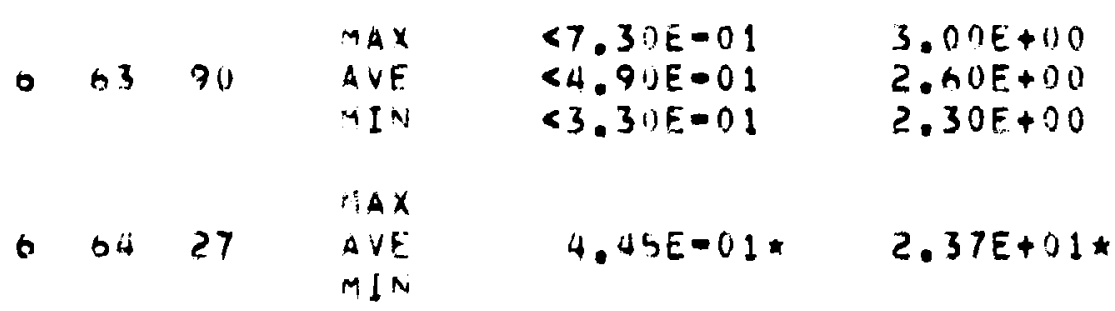

*-OS VALUES OR LESS, WO MAX OR MIN CALCULATED 


\begin{tabular}{|c|c|c|c|c|c|}
\hline \multicolumn{4}{|c|}{ NELL NII. } & $\begin{array}{l}\text { TRITIUM } \\
\text { PCI/ML }\end{array}$ & \multirow{2}{*}{$\begin{array}{l}\text { NITKATE } \\
\text { MG/L } \\
0.0-000 \\
3.175+00\end{array}$} \\
\hline 6 & 64 & 02 & $\begin{array}{l}\text { MAX } \\
\text { AVE } \\
\text { MIN }\end{array}$ & $3.73 E+00 \star$ & \\
\hline 6 & 65 & 23 & $\begin{array}{l}M A X \\
A V E \\
M I N\end{array}$ & $<4.85 E-01 \star$ & $1.90 E+00 *$ \\
\hline 6 & 65 & 50 & $\begin{array}{l}\text { MX } \\
\text { AVE } \\
\text { Iid }\end{array}$ & $1.25 E+(00) \star$ & $0.77 E-01 \star$ \\
\hline 0 & 65 & 59 & $\begin{array}{l}4 \Delta x \\
\Delta V F \\
M I: 1\end{array}$ & $1.10 E+1)(1 *$ & $<5.90 F-01 *$ \\
\hline 6 & as & 72 & $\begin{array}{l}\operatorname{Max} \\
\text { AVE } \\
\text { MI प }\end{array}$ & $\begin{array}{l}2.50 E+00 \\
2.1 P E+00 \\
1.00 E+00\end{array}$ & $\begin{array}{l}4.90 E+00 \\
4.05 E+00 \\
2.90 E+00\end{array}$ \\
\hline 6 & 65 & a3 & $\begin{array}{l}\text { MAK } \\
\text { AVE } \\
\text { MIN }\end{array}$ & $\begin{array}{l}2.00 E+00 \\
1.33 E+00 \\
9.20 E=01\end{array}$ & $\begin{array}{l}1.90 E+00 \\
1.73 E+00 \\
1.50 E+00\end{array}$ \\
\hline 6 & 65 & 38 & $\begin{array}{l}a \Delta x \\
A \vee t \\
\text { in I. }\end{array}$ & & $<5.0 \cup E-01 \star$ \\
\hline$n$ & 00 & 39 & $\begin{array}{l}A X X \\
A V E \\
A I N\end{array}$ & & $<5.00 E-01 *$ \\
\hline 6 & ho & 58 & $\begin{array}{l}\text { MAX } \\
\text { AVE } \\
M I R\end{array}$ & 1. DEE +On & $9.10 E-01 *$ \\
\hline 6 & 06 & 04 & $\begin{array}{l}\text { Max } \\
\text { MVF } \\
\text { MIN }\end{array}$ & $2.110+n(1 *$ & $1.77 E+60 *$ \\
\hline 6 & 60 & 103 & $\begin{array}{l}\text { MAX } \\
\triangle Y E \\
\text { MIN }\end{array}$ & $4.45 E=01 \hbar$ & $<5.00 E-01 *$ \\
\hline
\end{tabular}

t--3 values or less, No max or min calculated 


\begin{tabular}{|c|c|c|c|c|c|}
\hline \multicolumn{4}{|c|}{ NELL NO. } & \multirow{2}{*}{$\begin{array}{l}\text { TRITIUH } \\
\text { OCI/ML } \\
1.53 E+00 *\end{array}$} & \multirow{2}{*}{$\begin{array}{c}\text { NITRATE } \\
\text { MG/L } \\
=-0-0-0- \\
6.83 E=01\end{array}$} \\
\hline 6 & 67 & 51 & $\begin{array}{l}\text { PAX } \\
\text { AVE } \\
\text { MIN }\end{array}$ & & \\
\hline 6 & 67 & 86 & $\begin{array}{l}\text { MAX } \\
\text { AVE } \\
\text { MIN }\end{array}$ & $\begin{array}{l}1.50 E+00 \\
1.22 E+00 \\
8.80 E-01\end{array}$ & $\begin{array}{l}2.30 E+00 \\
1.47 E+00 \\
6.70 E=01\end{array}$ \\
\hline 0 & 67 & 98 & $\begin{array}{l}\text { MAX } \\
A V E \\
\text { MIN }\end{array}$ & $\begin{array}{l}<5.40 E-01 \\
<4.2 \cup E-01 \\
<3.30 E-01\end{array}$ & $\begin{array}{l}2.40 E+00 \\
2.03 E+00 \\
1.80 E+00\end{array}$ \\
\hline $\mathbf{b}$ & 65 & 125 & $\begin{array}{l}M A X \\
A V E \\
M I N\end{array}$ & $<5.25 E-01$ & $1.04 E+0 v$ \\
\hline 0 & 69 & $3 n$ & $\begin{array}{l}\text { AAX } \\
\text { AVE } \\
\text { NIN }\end{array}$ & $5.33 E=01 \star$ & $9.67 E-01 *$ \\
\hline$b$ & 70 & to & $\begin{array}{l}\text { MAX } \\
\text { AVE } \\
\text { MIP }\end{array}$ & $1.50 k+00 *$ & $0.75 E-01 \ldots$ \\
\hline 3 & 11 & 30 & $\begin{array}{l}\text { AXX } \\
\text { QVE } \\
\text { MIN }\end{array}$ & $<4.15 E-01 \star$ & $1.45 E+01 \star$ \\
\hline 6 & 71 & 52 & $\begin{array}{l}\text { MAX } \\
\text { AVE } \\
M 1 V\end{array}$ & $1.57 E+00$ & $3.10 E+10 *$ \\
\hline b & 71 & 77 & $\begin{array}{l}-4 A X \\
A V E \\
\text { MIN }\end{array}$ & $1.75 E+00 \star$ & $1.75 E+00 \star$ \\
\hline 6 & 72 & 73 & $\begin{array}{l}\text { AXX } \\
\text { AVE } \\
M I N\end{array}$ & $1.40 E+00 *$ & $1.03 E+00$ \\
\hline 6 & 72 & $B B$ & $\begin{array}{l}\text { AAX } \\
\triangle V E \\
M I N\end{array}$ & $\begin{array}{l}5.50 E+00 \\
4.53 E+00 \\
3.811 E+00\end{array}$ & $\begin{array}{l}3.50 E+00 \\
2.75 E+00 \\
1.90 E+00\end{array}$ \\
\hline
\end{tabular}

*-3 values or less, ho max oh min calculateo 


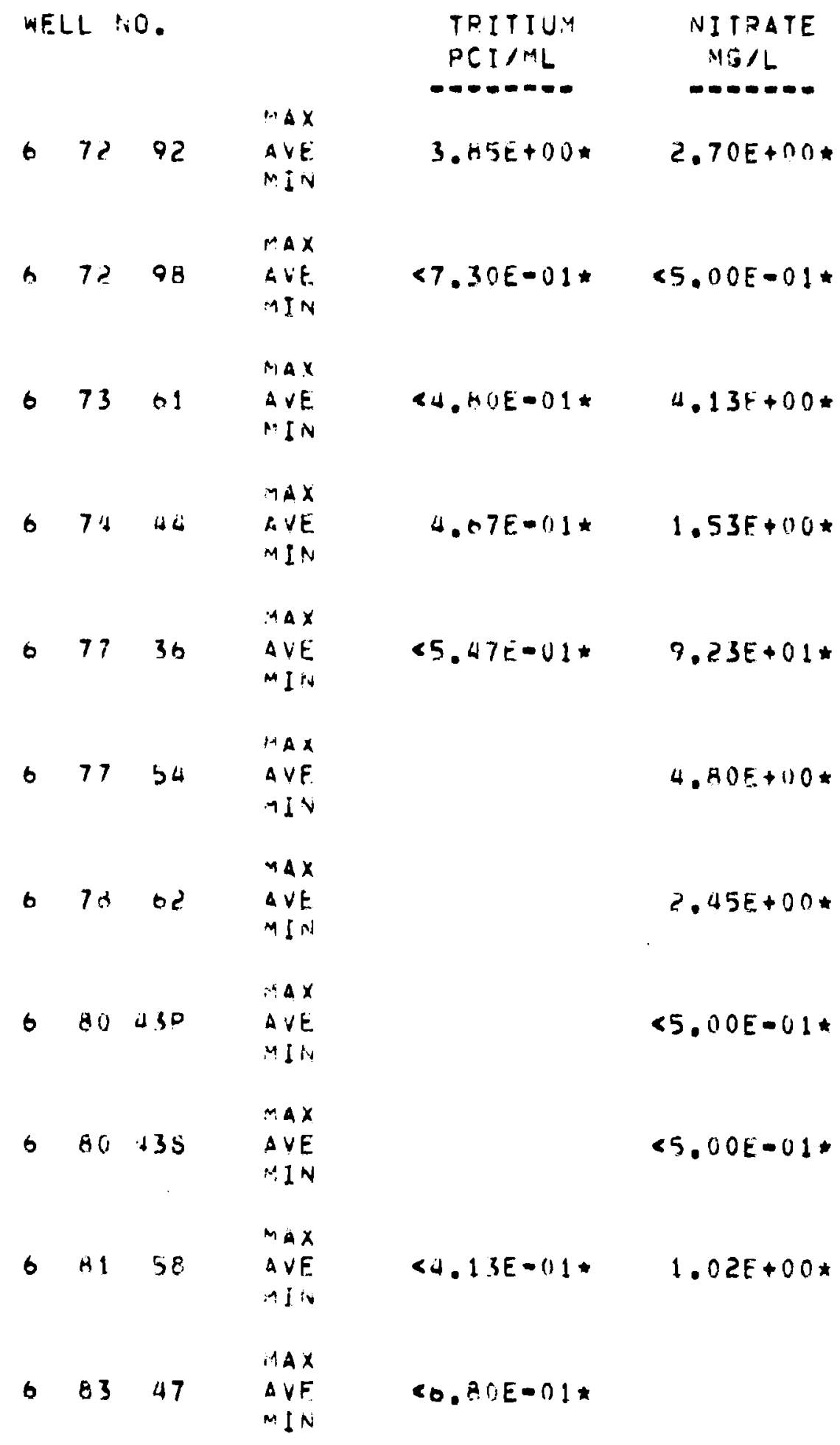

*- 3 values or less, ho max or min calculated 


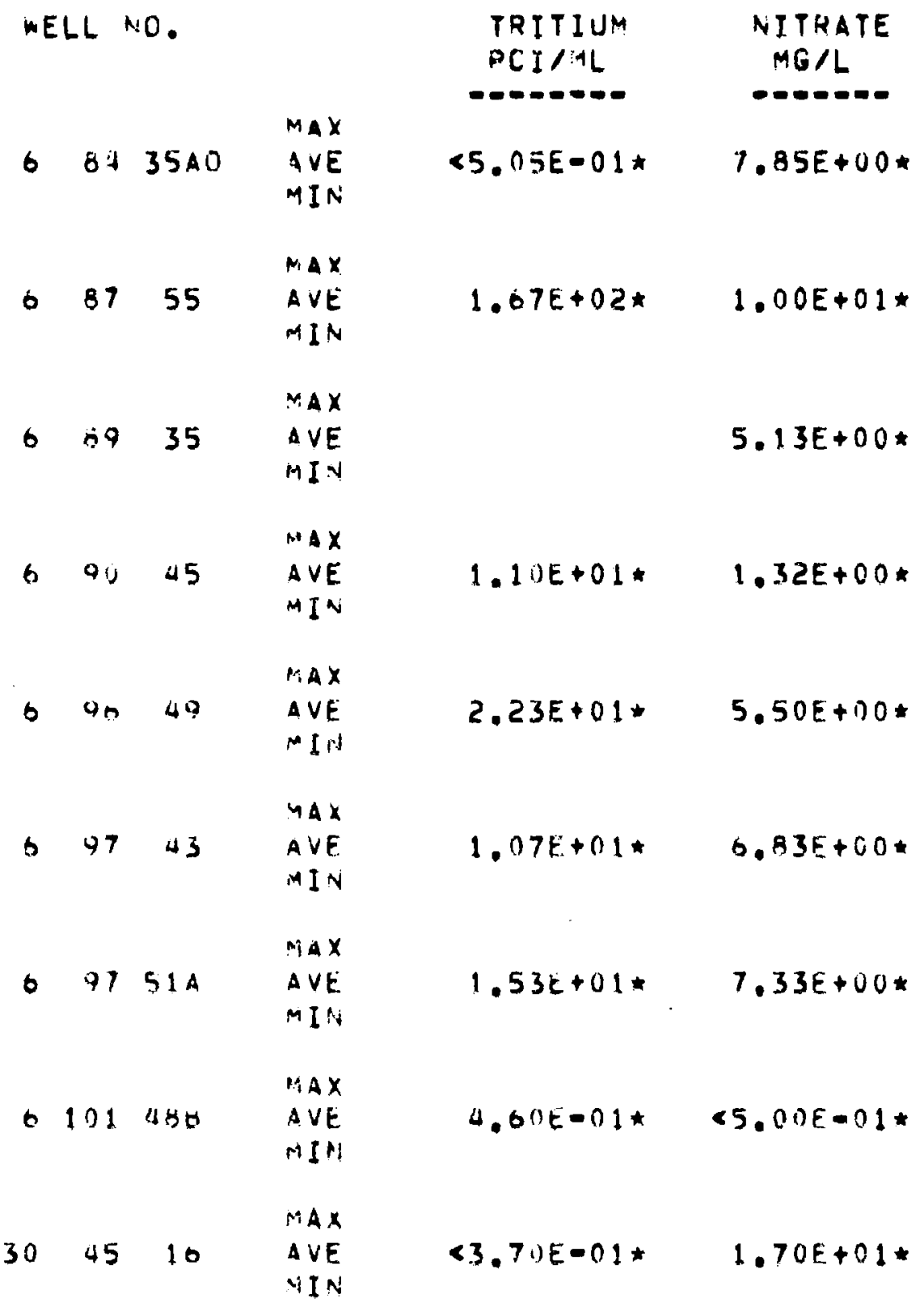





\section{APPENDIX B}

GROSS ALPHA, STRONTIUM-90, CESIUM-137, COBALT-60, URANIUM, RUTHENIUM-106, CHROMIUM, AND FLUORIDE CONCENTRATIONS IN THE GROUND WATER (UNCONFINED AQUIFER) 


\begin{tabular}{|c|c|c|c|c|c|c|c|}
\hline $\begin{array}{l}\text { WELL NOTE } \\
\text { UATE }\end{array}$ & $\begin{array}{c}\text { TUIAL ALPHA, } \\
\text { DEI ML } \\
-\end{array}$ & $\begin{array}{l}\text { STRONTIUM, } \\
\text { PRI INL }\end{array}$ & $\begin{array}{l}\text { CESIUM, } \\
\text { PCI/ML }\end{array}$ & $\begin{array}{l}\text { CORALY, } \\
\text { PCI/HIL } \\
-\end{array}$ & $\begin{array}{c}\text { UKANIUPI, } \\
\text { MG/L }\end{array}$ & $\begin{array}{l}\text { RUTHENIUK, } \\
\text { PCI/ML }\end{array}$ & $\begin{array}{c}\text { CHKOMIUM, } \\
\text { MG/L }\end{array}$ \\
\hline
\end{tabular}

33
$15-4 a r-a t$

$1 \lim _{12-M A Y=82}^{2}$

$2 \underset{1504}{15040}$

$1 \underset{12-M A T-P .2}{1}$
$4.95 E-1) 2$

$2.34 \varepsilon-02$

$5.14 E-02$

$<1,20 \leq-03$

$<2,70 E-03$

1443

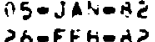
$50-4 A Y-a z$
5 i) $5-A U G-A$ ? 1) $5-\angle U G-A 2$
$27-O C T-32$

$12 t$

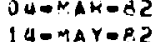

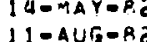

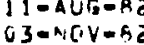

$10{ }^{3} \quad 3$ $0, M-N D V-B d 5$
$14-M A Y-B S$

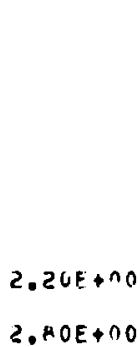

3. $20 E-01$

2. $A O E+0 O$

$3.60 E=01$
5. 50E-02

$<6.70 E-03$

$1.20 E-08$

$1.20 E-12$

$7.90 E-02$

$5.10 E-02$

1. $20 E-01$

$7.10 E=03$
$7.20 E=02$
$3.40 E-02$
$5.00 E-02$

$5.00 E=02$
$5.30 E-02$

$2.70 E+00 \quad 1.00 E-U 1$
$4.30 E+00$
$2.90 E+00$
$2.90 E-01$
$3.50 E-01$

$2.8 U E-01$
$3.50 E-01$ 


\begin{tabular}{|c|c|c|c|c|c|c|c|c|}
\hline $\begin{array}{l}\text { WELL VOU. } \\
\text { UATE }\end{array}$ & $\begin{array}{l}\text { TITAL ALPHA, } \\
\text { PCI, } \\
0.0 .\end{array}$ & $\begin{array}{l}\text { STRONTIUM, } \\
\text { PCI/ML } \\
\text { PCOM. }\end{array}$ & $\begin{array}{l}\text { CESIUA, } \\
\text { PCIIML } \\
\end{array}$ & \begin{tabular}{l} 
COBALT, \\
PCIIML \\
\hdashline$-\ldots .0$.
\end{tabular} & $\begin{array}{l}\text { URANIUM, } \\
\text { MG/L }\end{array}$ & $\begin{array}{l}\text { RUTHENIUM, } \\
\text { PCI/ML } \\
\text { PCO-O- }\end{array}$ & $\begin{array}{c}\text { CMRUMIUM, } \\
\text { HLIL }\end{array}$ & $\begin{array}{l}\text { FLUUORIUE, } \\
\text { MG/L }\end{array}$ \\
\hline $1 \begin{array}{c}\therefore \quad 4 \\
04-M A R-A 2 \\
14-1 i A Y-B 2 \\
03-N O V-82\end{array}$ & & $\begin{array}{r}\angle 4.50 E-03 \\
3.20 E-03\end{array}$ & & $\begin{array}{l}2.70 E-02 \\
3.40 E-02 \\
3.60 E-02\end{array}$ & & & & \\
\hline $\begin{array}{c}N \quad 5 \\
0 U-N A R=3 Z \\
11-M A Y-B Z \\
03-N O V-H Z\end{array}$ & & $\begin{array}{l}1.70 E=02 \\
3.90 E=01\end{array}$ & & $\begin{array}{l}4.20 E=02 \\
4.30 F=02 \\
5.30 E=-22\end{array}$ & & & & \\
\hline $1 \begin{array}{c}V \\
114-Y A D-A 2 \\
14-H A Y-B 2 \\
O S-N O V-A 2\end{array}$ & & $\begin{array}{l}3.00 E=02 \\
3.30 E-02\end{array}$ & & $\begin{array}{l}4.50 E=02 \\
5.10 E-02 \\
3.40 E=02\end{array}$ & & & & \\
\hline 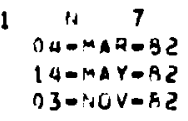 & & $\begin{array}{l}3.20 E=02 \\
4.10 E=03\end{array}$ & & $\begin{array}{l}2.20 E-n 2 \\
2.00 F-02 \\
3.70 E-n 2\end{array}$ & & & & \\
\hline $1 \begin{array}{c}11 \\
0 U-M A F-B Z \\
14-M A Y-B 2 \\
03-11 O V-B 2\end{array}$ & & $\begin{array}{l}1.60 E-01 \\
1.60 E-01\end{array}$ & & $\begin{array}{l}5.10 E-02 \\
9.60 E=0.2 \\
8.80 E=-25\end{array}$ & & & & \\
\hline $\begin{array}{c}N \quad 15 \\
O 4-N A K=B Z \\
14-N A Y-A 2 \\
O S-N O V-A Z\end{array}$ & & $\begin{array}{l}3.50 E-03 \\
7.70 E-03\end{array}$ & & $\begin{array}{l}2.80 E-02 \\
3.50 E-02 \\
4.20 E-02\end{array}$ & & & & \\
\hline $\begin{array}{c}N \quad 16 \\
14-M A Y-82 \\
D 3-N O V-82\end{array}$ & & $\begin{array}{r}4.90 E=03 \\
<1.20 E=03\end{array}$ & & & & & & \\
\hline $\begin{array}{c}N 17 \\
14-M A Y-\theta ? \\
13-N O Y-A S\end{array}$ & & $\begin{array}{l}9.00 E-03 \\
1.20 E-02\end{array}$ & & $1.20 E-02$ & & & & \\
\hline
\end{tabular}




\begin{tabular}{|c|c|c|c|c|}
\hline $\begin{array}{l}\text { KELL NO. } \\
\text { WATE }\end{array}$ & $\begin{array}{l}\text { TOTAL ALHHA, } \\
\text { PCIML } \\
0\end{array}$ & $\begin{array}{l}\text { STRONTIUYA, } \\
\text { PCI/ML } \\
\end{array}$ & \begin{tabular}{l} 
CESIUA, \\
PCI/ML \\
\hdashline
\end{tabular} & $\begin{array}{l}\text { COHALT, } \\
\text { PCI/ML }\end{array}$ \\
\hline $\begin{array}{cc}10 & 5 \\
2 n-J U L & -82\end{array}$ & & & & $1.30 E-02$ \\
\hline $\int_{1}^{10-3 c t=n z}$ & & & & $0.308-03$ \\
\hline $27 \begin{array}{c}21 \\
27-3 ! L-82\end{array}$ & & & & $2.30 E-02$ \\
\hline
\end{tabular}

\begin{tabular}{|c|c|c|}
\hline 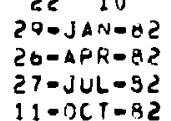 & $\begin{array}{l}<1.70 E=02 \\
<1.70 E=02 \\
<1.70 E=02 \\
<1.70 E=02\end{array}$ & $\begin{array}{l}3.00 E-03 \\
4.00 E=-13 \\
7.30 E=03 \\
3.30 F=03\end{array}$ \\
\hline
\end{tabular}

311 $13-J A M-65$
$0-A P H-B S$

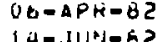
$14-J U \times-65$ cu-SEPAd ?9-AUV-B?

3125 $07-J A N-A C$ $O D-A P R=82$ 15-JUNAC I $6-S E P-82$

$9.40 E-03$

$1.40 E-02$

$1.50 E-02$

$2.80 E-02$

$<0.70 E=03$

$<6.70 E-03$

$4.40 E=02$

$2,20 E-02$

$2.40 E-02$

313 OT-JAN-82 UOA I 1 -JUNARE
$2.00 E-02$

$0.70 E-02$

$3.90 E-02$
$2.70 E=02$

\begin{tabular}{|c|c|}
\hline $\begin{array}{l}6.1 \cup E=03 \\
9.00 E-03 \\
4.30 E=0.3 \\
9.50 E-03 \\
8.60 E=03\end{array}$ & $\begin{array}{l}4.20 E-U 1 \\
3.60 E-U 1 \\
3.00 E-U 1 \\
4.00 E-U 1 \\
4.00 E-01\end{array}$ \\
\hline $\begin{array}{l}a .20 E-0 S \\
1.30 E-02\end{array}$ & $\begin{array}{r}1.20 E=01 \\
<1.00 E-01 \\
3.20 E-U 1\end{array}$ \\
\hline $\begin{array}{l}1,10 E=02 \\
3.20 E=03\end{array}$ & $\begin{array}{l}3 . \triangle 0 E-U 1 \\
3.00 E-U 1\end{array}$ \\
\hline
\end{tabular}

$4.30 E-03$

$4.30 E-U 3$
$1.20 E-02$

$1.20 E-02$

3. $40 E-01$

$2.000=01$

$2.80 E=0$
$3.20 E=0$ 


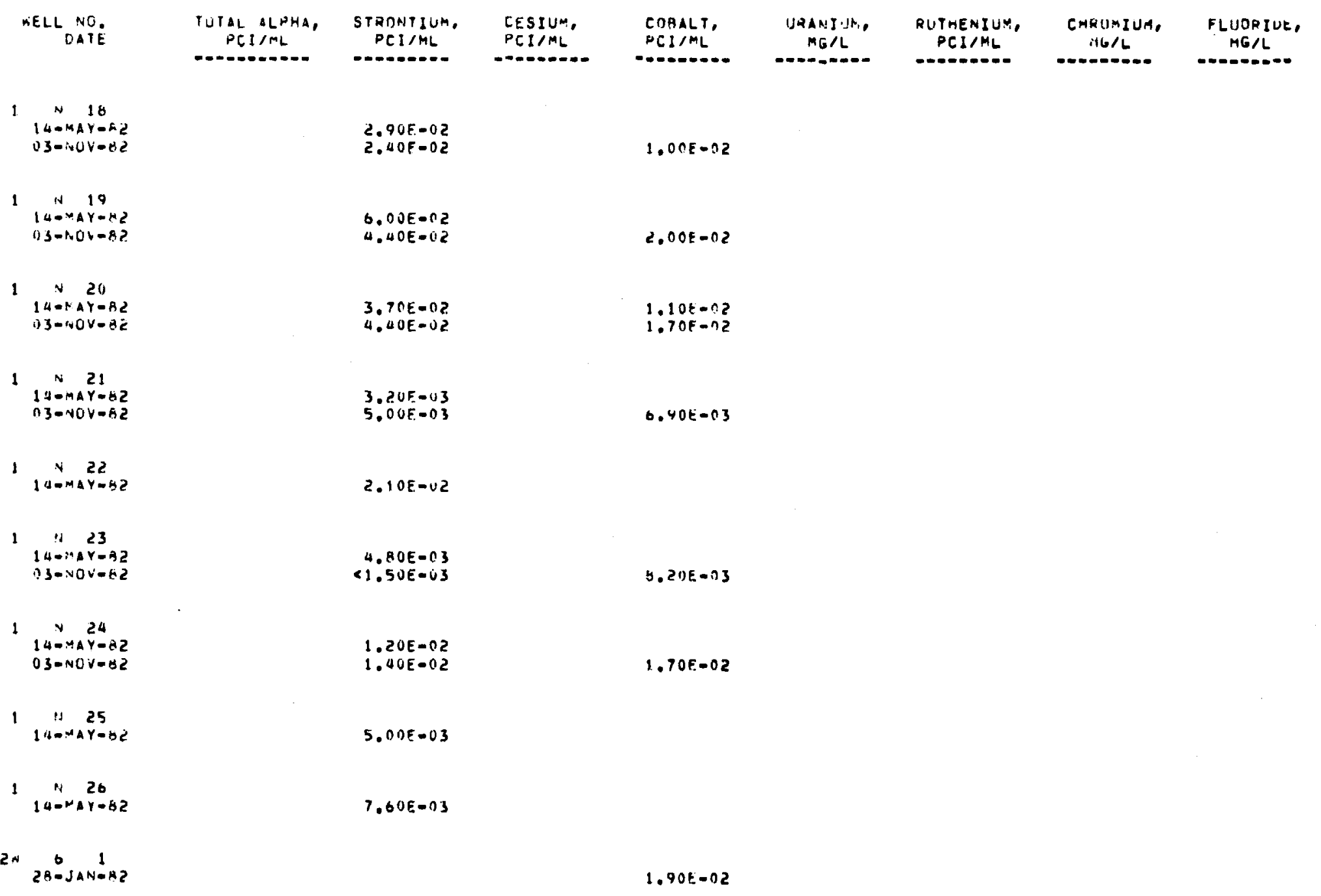




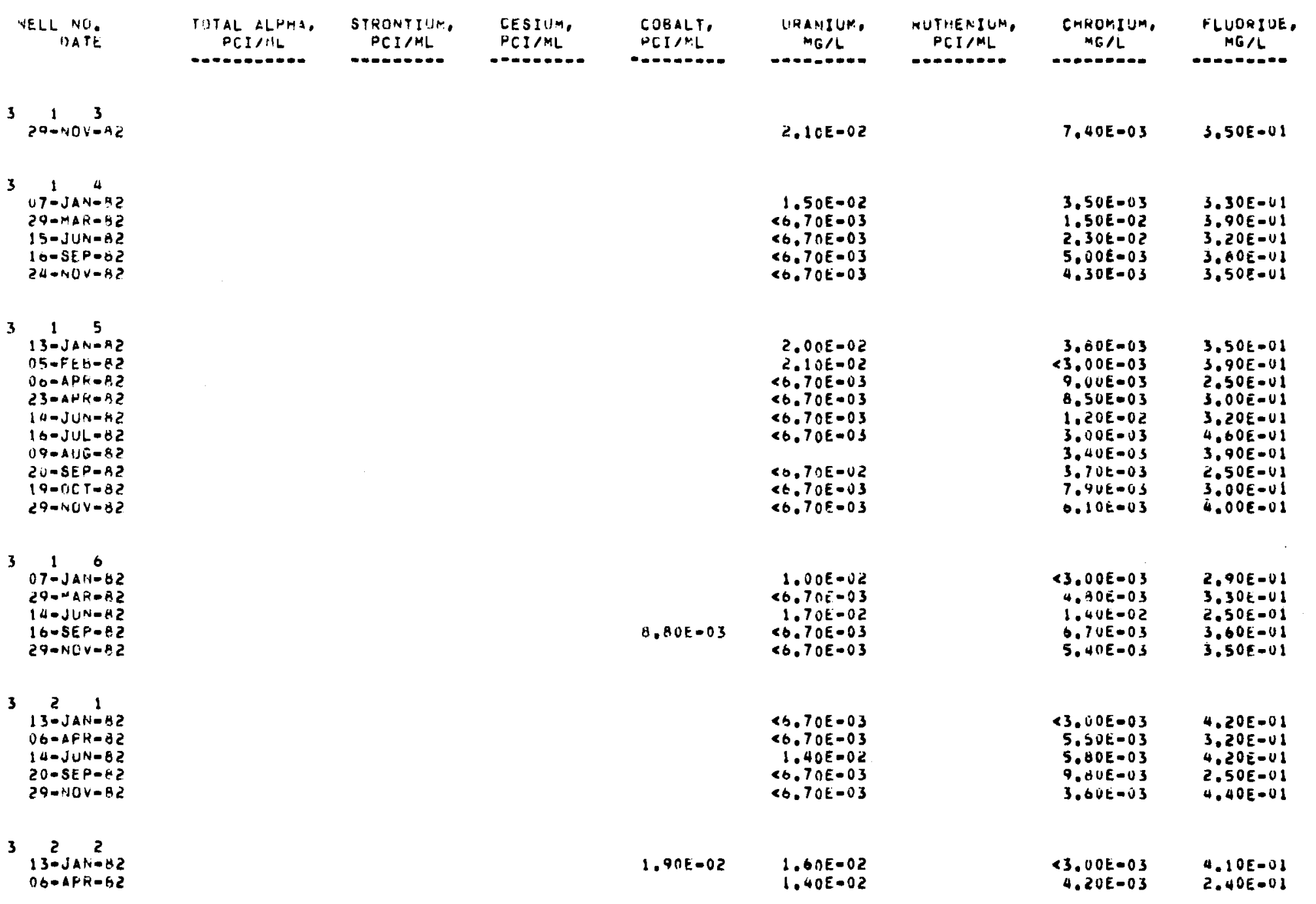


(5Y 1962)

WELL Nก.

HITMENI UM

CARUAI IUM.

FLUOHJUE,

UATE

PCI/AL

PCIML

PCIIML

MG/L

PCI/ML

MG/L

MG/L $3 \begin{array}{cc}2 & 2 \\ 14-J U V-32 & 20-5 E P-H z\end{array}$ $29-A O V-A 2$

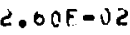

$2.60 \mathrm{E}-U 2$
$1,70 \mathrm{~F}=\mathrm{UL}$

$1.00 E-02$

<3. OUE $=03$
$4.10 E-O 3$

$4.70 E-U 1$

$3.00 E=01$

$2.10 E=01$

$33^{3}$

$13-J A A-A 2$
IS-APR-BZ

$50-3 E P-5 ?$

20-NOV-8Z

<b. 7 cit -13

1.00E-UZ

$<0.70 E-113$

$<0,70 E-02$
$<t, 70 t=03$

<3.00E-1)3

$3.30 E-0.3$

$1.20 t=02$

$3.40 t=03$
$3.70 t=03$

2. $90 E-01$

$1.50 E-I J$

S. OOE 0 I

$3.60 E=01$
$3.00 E-O 1$

$3 \quad 31$

$13-J A N=C 2$
$U G-A P R=A 2$

UG-APR-A?

$14-J U N-B 2$

ZU-SEP-B?

$<6.70 E-U 3$

CO.7OE-OS

Ch. 7 UE-03

1. DOE - U2

<3.0uE -03

$5.00 E-03$

5. OUE -03

$\angle 3.0 U E-O 3$

$3.60 E-01$

$3.00 E-U 1$

$7.904-113$

CO.7OE-US

$3.30 E-01$

$2.00 E-U 1$

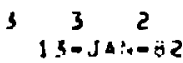

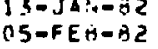

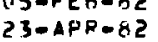
$23-\triangle P R-B 2$
$19-U C T=O ?$

$1.101=1.5$

$\begin{array}{r}1.5 O E-U 12 \\ 1.00 E-U 2 \\ 1.40 E-U E \\ \text { S. } \\ \hline\end{array}$

$7.0 U E=03$
$\angle 3.0 \cup E=03$

333

$17 S-F E A-A B$
$13-J A N-B S$

1) 13 -FEADAR?

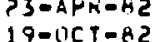

$<0.7 \cap E-03$

$<0.70 E-03$

$<6.70 E=03$
$<0.70 E-03$

C.
$1.10 E-O D$

$2.00 E-01$

$1.90 E=01$
$2.50 E-01$

4.7 UE -03

336

$13-J A N-82$
$05-F E A-A 2$

OS-FEA-A?
10 MARAB?

10-MAR-B?
$16-A P R=85$

$23-1 P K-B 2$

1
$5 O M A Y-O S$

$<0,70 E=23$

$<0.70 E-U 3$

$1.30 E-02$
$6,70 E-03$

$40.70 E-03$

$1.40 E-02$

$1.70 E-02$

C3.0OE=03 2.SOE-01

$4.3 \cup E-03 \quad 2 .+0 E=01$

$0.6 U E=03 \quad 2.20 E-01$
$9.00 E-03 \quad 2.30 E-U I$

$2.40 t-n 2$

$6.00 E=03 \quad 2.70 E=U 1$

$0.10 E=03 \quad 3.20 E=01$

$7.40 E-03 \quad 3.10 E-01$

1.5UE-0Z 2.70E-UI

$9.00 E=03 \quad 2.90 E-U I$

1. $10 E=02$ S. $10 E=01$

$1.20 E-02 \quad 2.70 E-01$ 
(CY 19k2)

\begin{tabular}{|c|c|c|c|c|c|c|c|c|}
\hline NELL NQ: & $\begin{array}{l}\text { TUTAL ALPHA, } \\
\text { OCI IALL } \\
.\end{array}$ & $\begin{array}{l}\text { STRUNTIIIM, } \\
\text { PCIIML } \\
-10 .\end{array}$ & $\begin{array}{l}\text { LESIJM, } \\
\text { PCIMLL } \\
\text { PCOA }\end{array}$ & $\begin{array}{l}\text { CONALT, } \\
\text { PCIML } \\
\end{array}$ & 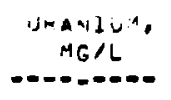 & 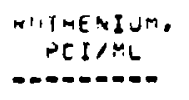 & $\begin{array}{c}\text { CHEOHIUM, } \\
\text { MG/L }\end{array}$ & $\begin{array}{l}\text { PLUUYIUL, } \\
\text { MG }\end{array}$ \\
\hline 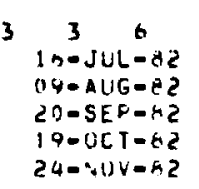 & & & & $7.20 \mathrm{E}-03$ & $\begin{array}{l}1.00 E=02 \\
1.1 \cap E=02 \\
1.10 E-02 \\
1.10 E=02\end{array}$ & & $\begin{array}{l}3.1 U E-O 3 \\
3.1 U E=03 \\
3.40 E-03 \\
1.10 E-0 ? \\
5.00 E=03\end{array}$ & $\begin{array}{l}3.30 E=01 \\
3.00 E=01 \\
5.00 E-U 1 \\
2.00 E-01 \\
3.40 E-01\end{array}$ \\
\hline 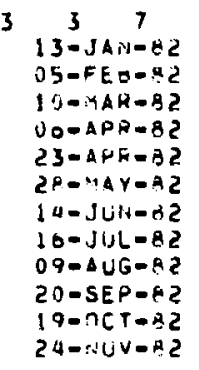 & & & & & $\begin{array}{r}1.00 E-02 \\
66.70 E-03 \\
66.70 E=613 \\
1.40 E=02 \\
<6.70 E-03 \\
1.10 E-02 \\
1.70 E=02 \\
1.30 E=02 \\
1.40 E-02 \\
1.10 E=02 \\
1.00 E=02\end{array}$ & & $\begin{array}{l}\text { 3. UUE=03 } \\
4.50 E=03 \\
3.70 E=03 \\
0.20 E=03 \\
0.70 E=03 \\
1.00 E-02 \\
2.00 E-02 \\
7.40 E=03 \\
4.10 E-03 \\
3.70 E-03 \\
5.30 E=03 \\
4.5 U E=03\end{array}$ & $\begin{array}{l}2.40 E-U 1 \\
3.60 E-01 \\
2.60 E-U 1 \\
2.00 E-01 \\
1.60 E-U 1 \\
3.10 E-U 1 \\
3.50 E=01 \\
4.10 E=01 \\
3.50 E=01 \\
3.10 E=01 \\
3.2 U E-V 1 \\
3.00 E-61\end{array}$ \\
\hline $3 \begin{array}{c}3 \\
3 \\
B 7-J A N-B 2 \\
U S-F E O-82 \\
23-A P R-A 2 \\
19-O C T-82\end{array}$ & · & $\begin{array}{r}<2.00 E-03 \\
2.00 E=01 \\
3,00 E=03 \\
<3.00 E-03\end{array}$ & & & $\begin{array}{r}1.50 E-02 \\
<6.7 \mathrm{AE}-U S \\
1.00 E-U 2 \\
2.00 E-02\end{array}$ & & $\begin{array}{l}<3.00 E-03 \\
<3.00 E=03 \\
0.50 E=03 \\
<3.00 E=. J 3\end{array}$ & $\begin{array}{l}5.30 E-U 1 \\
4.30 E-U 1 \\
3.30 E-01 \\
2.90 E-U 1\end{array}$ \\
\hline $3 \begin{array}{c}310 \\
07-J A N-A Z \\
O S-F E Y-A Z \\
P 3-A P R-B ? \\
14-D C T-B Z\end{array}$ & & $\begin{array}{r}1.10 E-02 \\
7.50 E-03 \\
22.00 E-03 \\
1.40 E-02\end{array}$ & & & $\begin{array}{r}1.00 E-112 \\
1.00 E-02 \\
6.70 E=-113 \\
2.00 E=02\end{array}$ & & $\begin{array}{l}\angle 3.00 E-U 3 \\
\angle 3.00 E=03 \\
4.20 E=03 \\
\angle 3.00 E-03\end{array}$ & $\begin{array}{l}4.00 E-U 1 \\
5.40 E-U 1 \\
4.30 E-01 \\
3.60 E-U 1\end{array}$ \\
\hline $3 \begin{array}{c}3 \\
13-J A \\
13-J A 2 \\
25-F E B-A 2 \\
23-A F R-A 2 \\
19-O C T-82\end{array}$ & & $\begin{array}{l}1.50 E=02 \\
1.20 E=02 \\
9.90 E=03 \\
8.20 E-03\end{array}$ & & $\begin{array}{l}1.30 E-n z \\
7.40 E=1) 3\end{array}$ & $\begin{array}{l}3.2 \cap E-112 \\
2.90 E-112 \\
1.50 E-02 \\
2.40 E-02\end{array}$ & & $\begin{array}{r}\angle 3.00 E-03 \\
\angle 3.00 E=03 \\
4.5 U E=03 \\
3.30 E-03\end{array}$ & $\begin{array}{l}2.00 E-01 \\
3.00 E-01 \\
3.60 E-01 \\
3.00 E-01\end{array}$ \\
\hline
\end{tabular}


MELL POO TOTAL ALPHA,
DCI MLE
. PCIIML

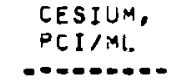

PCI/YL

$33_{3}^{0} 15$ $07-7 A N-B 5$ O5-FEOAC $1 U=M A R-E Z$ $00-A P R=A 2$ $23-A P K-B 2$
$3 g-M A Y-B=$

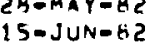

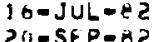

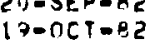
$24-n 0 V-82$

\section{$3 \lim _{1}^{1}$} 19-MAR-AL 14 -JUNEB? (1) $-S E P-52$ $29-N O V-82$

$3 \lim _{1}$ $01-3 A N-45$ i dojuratos 10-JUNu o? Cuncpara

349 (1) $7-3 A N-82$

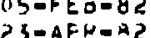

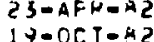

3410 ODAJUAE?
OT-JANAES

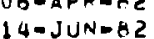

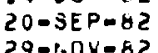

$$
\begin{array}{r}
<2.1) O E=1) 3 \\
2,90 E-03 \\
<2.00 E=03 \\
<2,50 E-03 \\
2.30 E=03 \\
6,30 E=02 \\
<2.50 E-03 \\
4.20 E=03 \\
<1,90 E=03
\end{array}
$$

$1.30 E-12$
$0.70 E-03$

$0.70 E=03$
$<3.00 E=03$
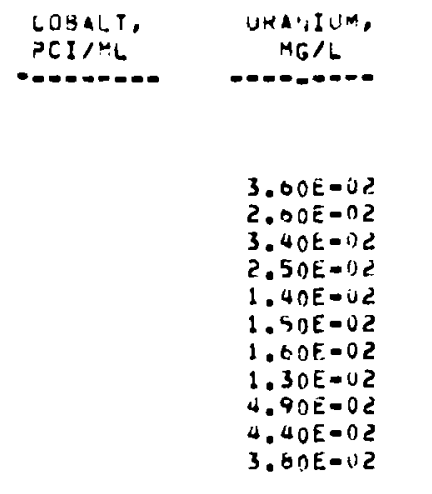

RUTHENIUM

PCIITL

C.TFOMLU. $M G / L$

FlLORIUE, MG/L

3. OOE-UZ

2. $00 E-02$

$3.40 E-1) C$
$2.50 E-1) C$

$1.40 E-U 2$

$1.5 D E-02$

$1.60 E-02$

$1.30 E=02$

$4.90 E=02$

$4.40 E=02$
$3.00 E=12$

$1.8 \cap E-02$

$1.80 E-02$

1. $\triangle$ CE-UL

$1.50 E=02$
$<0.70 E-03$

$3.70 F-02$

$2.3(B E-1) 5$

$2.20 E=02$

$1.90 K=02$
$2.90 E=02$

$1.9 O E-02$

$2.40 E-02$

$1.7 O E-O C$
$1.7 O E-O L$

$0.40 t-03$

$2.70 E-112$

2. $10 E-02$

$1.60 E-02$

$1.70 E-02$

$1.40 E-02$

$<0.70 E-03$
$4.30 c=03$

S. SUE $=0$

$0.10 E-03$
$7.00 E-O S$

$7.0 O E-O 3$
$1.0 O E-1)$

$1.00 E=1 J 5$
$1.00 E=02$

$1.10 \mathrm{e}=02$

$0.7 U E-03$

$1.00 t-02$

$3.30 t=03$
$5.4 U E=03$

3. $80 E-01$

3. $40 E-U 1$

3. $q U E-U 1$

3. OOE 01

3. $50 E=01$

$3.20 E=01$

2. 00 E $0 \mathrm{I}$

$4.00 E-U 1$

S.IOE-OI

$2.50 E=U 1$
$3.50 E=U 1$

$7.0 U E-J 3$

$7.40 E-03$

$1.3 U E=02$

S. $10 E=03$

3. $20 E-U 1$

3. $50 E-U 1$

2.7OE=U

C. $10 E=U I$

4.3 $30 E-0.3$

$6.0 U E=03$

$8.10 E=03$

$1.10 E=02$

4.6Ut-U1

$3.40 E-U 1$

$3.00 E=01$

3.50 U.

43. $00 E=03 \quad 3.80 \mathrm{E}=01$

$5.30 E-03 \quad 3.70 E=0$.

$\begin{aligned} & 7.10 E-03 \\ & \text { 2. }\end{aligned} 0 \mathrm{E}=U \mathrm{I}$

<3. $00 \mathrm{E}=0$ S

$5.00 E-1) 3$

$7.10 E=03$

$1.90 E=03$

$<3.00 E=03$
3. $B O E-01$

3. उUE-O!

2. $3 O E-U I$

2.70E-UI

3. $20 E-V I$ 
WELL ROS

TOTAL ALHAE,

STRUNTIUM, GESIUN, PCI/ML

PCI ML

35

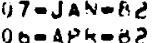

$15-J U N-8 z$

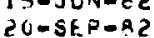

$540 \operatorname{sur} t 5$

$3 \begin{gathered}3 \\ 13-J A M-B\end{gathered}$

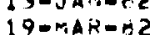

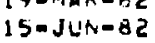

16-SEP-H?

$\underset{6}{0}$

COAALT

PCI/ML

URARIUK,

MGL

HLTHENIUM

CHRUALIUM

MG/L

FLUURIUE PCI/ML

MG L

$<6.70 E-03$
$<0.70 E-03$

$<0,70 E-C S$

$\angle 0.70 E-03$

$<.70 E=03$

3. SUE-US

$1.00 E-\dot{0} 2$

$8.0 U E=03$

5. $3 \cup E=03$

$2.00 E-U 1$

$1.90 E-U 1$

$1.90 E-U 1$
$1.70 E-U I$

$2.50 E=U 2$

(h. $70 E-1) 3$

$<6.70 E-03$

$<6.70 E-03$

$<6.70 E-03$

$\angle 0.70 E=03$

$4.5 U E-03 \quad 2.50 E-U 1$

1. $.00 E-02 \quad 3.10 E-01$

$1.20 E-U 2 \quad 2.30 E-01$

$\begin{array}{ll}7.0 O E-U 3 & 2.30 E-U 1 \\ 0.10 E-03 & 1.00 E-U 1\end{array}$

66.70E-03

$<6.70 E-03$

$66.70 E=03$

$<6.70 E=03$

$<6,70 E-03$

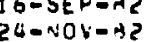

$1.00 E-02$

3 a 5

$07-J A B-B z$

19-MAK-HC

15-JUHEB?

$16-S E P-62$

$3 \int_{3-J A N-8 S^{3}}^{3}$

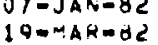
$15-J U N=85$
$10-M A R=95$

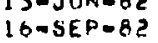

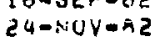

$6.70 E-015$

$\angle 6.70 E-113$

$66.70 E=03$

$6.70 E-03$

$9.30 E-03$

$66.70 E=03$

$\angle 0.70 E-03$

$\angle 6.7 D E-03$

$<6.70 E=03$

$<6.70 E-03$

$1.10 E-02$

$<6.70 E-03$
$<6.70 E-03$

$<6.70 E=03$

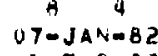

$U S-F E A-B C$

Q3. OCE-03 2.70E-U1

$0.20 E=03 \quad 3.10 E=01$

$5.80 E-03$ 2.10E-U

$\begin{array}{rl}5.30 E-03 & 2.30 E-U 1 \\ <3.00 E-03 & 2.30 E-U 1\end{array}$

3.2UE-03 2.80E-OI

$0.10 E=03 \quad 3.00 E=U 1$

$1.50 E-02 \quad 2.40 E=U 1$

$5.6 U E=03 \quad 2.40 E-U D$

C3.0UE-03 2.70E-UI

$\begin{array}{rr}2.00 E-03 & 3.20 E-U 1 \\ 0.2 U E-U 3 & 3.10 E-U 1 \\ 1.10 E-02 & 2.00 E=U 1 \\ 0.9 U E-03 & 2.00 E-U 1 \\ 2.00 E-03 & 3.00 E=U 1\end{array}$

2.00E-UI

C3. $00 E-03 \quad 2.90 E-U 1$

$3.20 E-03 \quad 3.20 E-01$ 


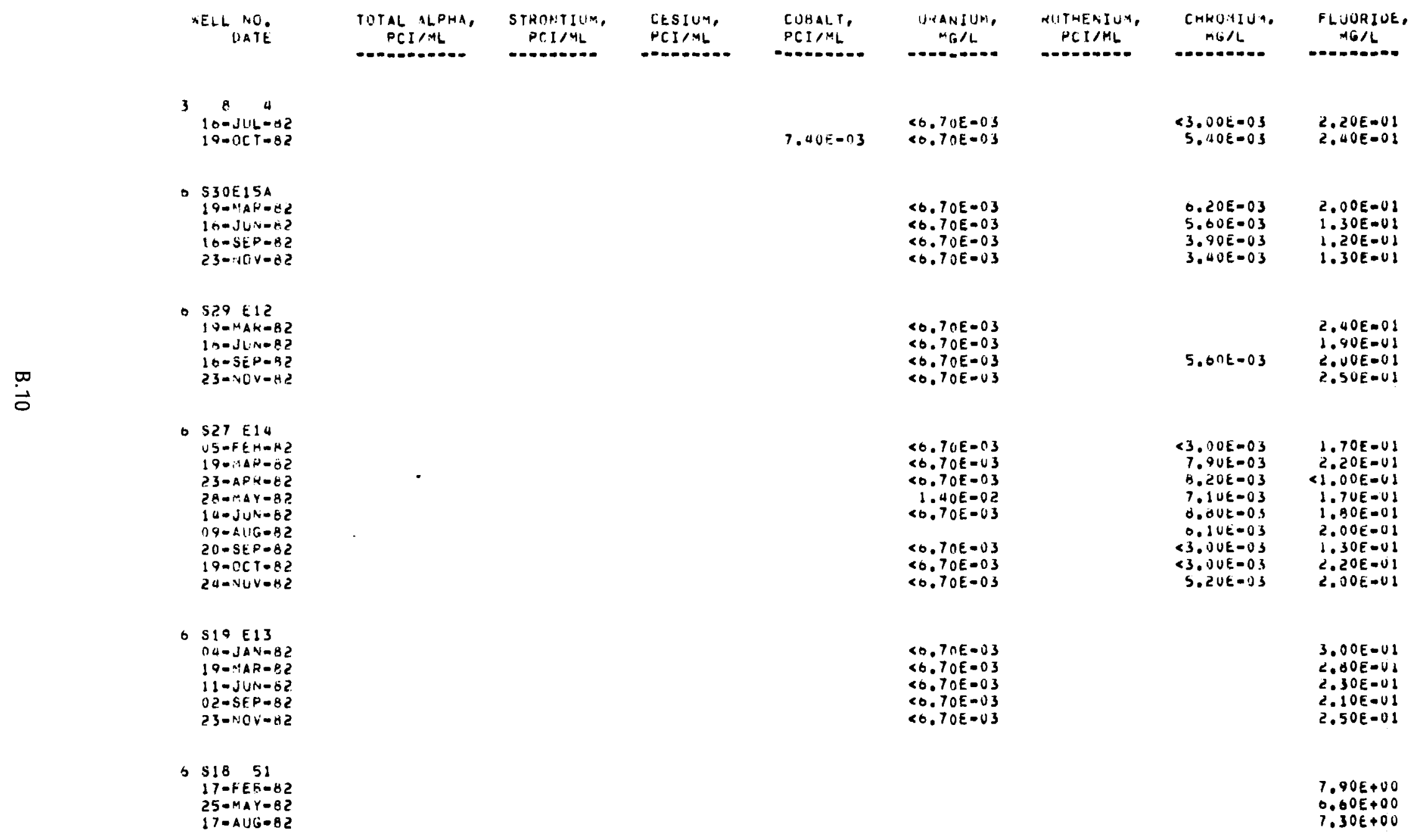


(Cr 1982)

page 11

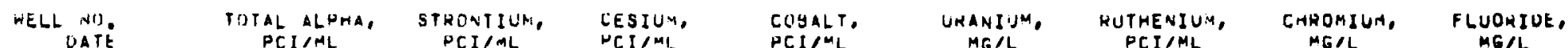
PCI/ML

MGL

PCIIML

MGIL

GG/L

OS-JAHARE

26-MAN-A2

$17-j U N-B 2$

O7-SEP- 25

3) 1 MUV-A2

- So $t+0$

OS-JAN-H?

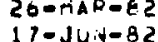

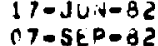

$3 U-m U V-8 z$
$07-5 E P-85$

$51 \underset{7 b}{30-n i r s}-92$
0

$30 \quad 7$
$30-v a v-42$

$1.70 E-02$

13 IC
$02-C E C-85$

$19 \quad 58$
$06-J U L-32$

- 2020

$13-D E C=A B$
$31-A, E$

b $20 \quad 15$

$\begin{array}{lll}6 & 27\end{array}$ $04-j A+j-e z$
$19-x A k-82$
$.50 E-02$

1.405 .02

$4.20 E=\cap 3$

$<6.70 E-03$

$<6.70 E-0 S$

$<0.70 E-05$

$<6.708-03$

$<0.70 E-03$

$<0.70 E-0 S$

$<0.70 E=03$

$<6.70 E-U$

$\angle 0.7$ OE= 0

$<6.70 E-U S$

$2.00 E-01$

$7.30 E-03$

$6.20 E-03$

$1.20 E-02$

$1.80 E-02$
$1.60 F-02$ 
(CY 1782)

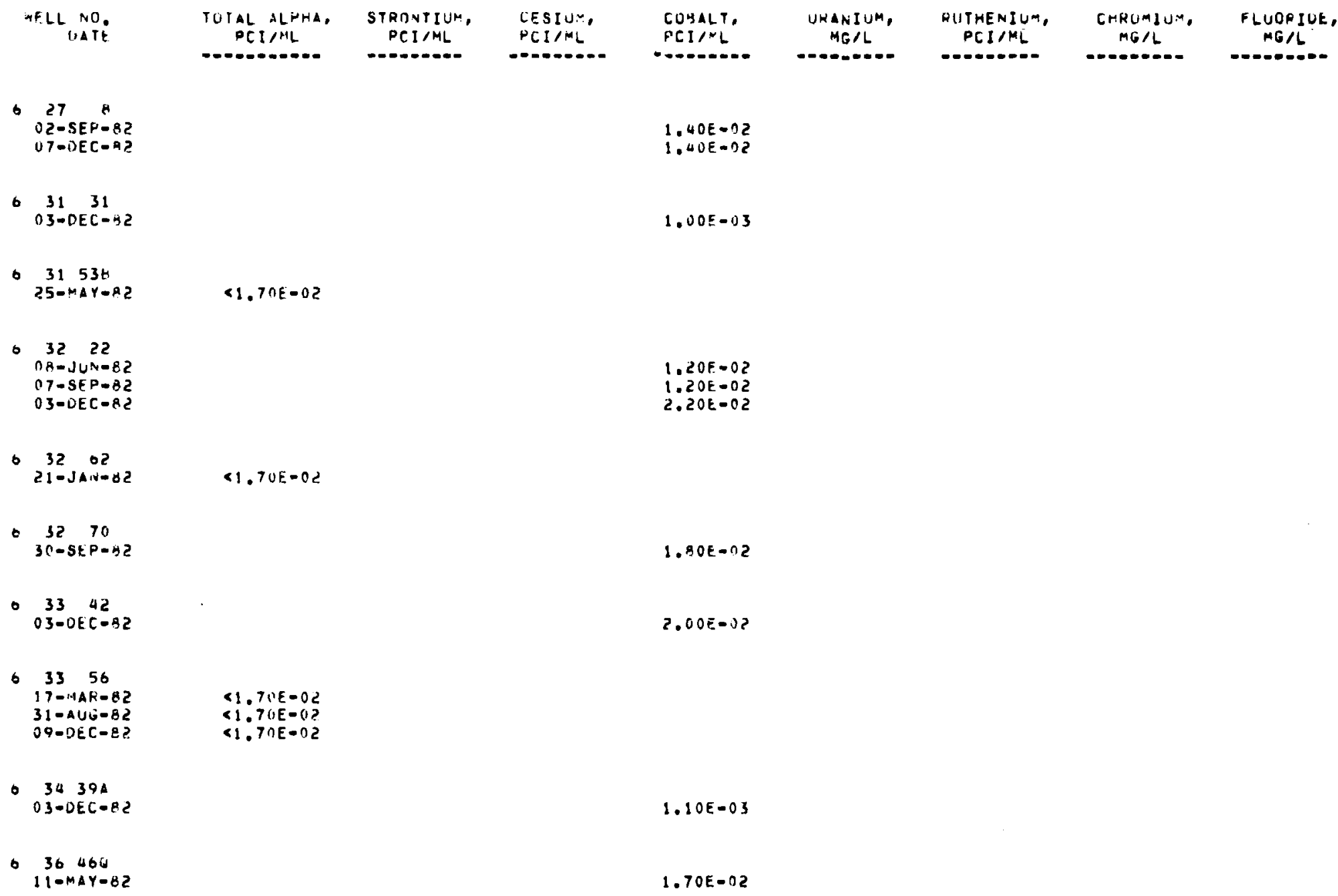$$
11.7 \cap E=02
$$

$1.206-05$ $1.20 E-02$ $2.20 t-02$

$1.80 E-02$

$2.00 E=32$

$1.10 E-03$

$1.70 E-02$ 


\begin{tabular}{|c|c|c|c|c|c|c|c|c|}
\hline $\begin{array}{l}\text { WELL NOE. } \\
\text { DATE }\end{array}$ & $\begin{array}{c}\text { TOTAL ALPHA, } \\
\text { PC,I/ML } \\
\end{array}$ & $\begin{array}{c}\text { STRONTIUM, } \\
\text { PCI/ML }\end{array}$ & $\begin{array}{l}\text { CESIUA, } \\
\text { PCIMAL } \\
-\end{array}$ & $\begin{array}{l}\text { COGALT. } \\
\text { PCI/ML } \\
\end{array}$ & $\begin{array}{l}\text { UHANIUM, } \\
\text { MGLL }\end{array}$ & $\begin{array}{l}\text { RUTKENIUM, } \\
\text { PCI/ML }\end{array}$ & $\begin{array}{c}\text { CHROMIUM, } \\
\text { KG/L }\end{array}$ & PLUORIUE, \\
\hline $6 \begin{array}{c}3805 \\
01=0 E C=9 ?\end{array}$ & & & & $7.40 E=03$ & & & & \\
\hline $6 \begin{array}{c}39 \quad 1 \\
2 Z-F E B-52 \\
1 D-M A H-A 2 \\
30-A L G-B 2 \\
27-S E P-B 2 \\
25-O C T-B ?\end{array}$ & & & & $\begin{array}{l}1.20 E-02 \\
1.90 E-n ? \\
1.10 E-n 2 \\
1.00 E-n 2 \\
1.10 E-n 2\end{array}$ & & & & \\
\hline $\begin{array}{c}3979 \\
29-J A N-82 \\
11-0 C T-82\end{array}$ & & & & $\begin{array}{l}1.90 E-122 \\
1.00 E=-12\end{array}$ & & & & \\
\hline $6 \begin{array}{c}42,2 A \\
30-\triangle U G-82 \\
07-D E C-A 2\end{array}$ & & & & $\begin{array}{l}9.90 F=n 3 \\
8.60 F=n 3\end{array}$ & & & & \\
\hline $6 \begin{array}{c}45 \quad 42 \\
27-J A 4-82\end{array}$ & & & & $2.305-12$ & & & & \\
\hline $6 \begin{array}{c}4569 \\
01-U E C-82\end{array}$ & & & & $7.00 E=13$ & & & & \\
\hline 6 $\begin{array}{c}49 \\
25-J 4+4=22\end{array}$ & & & & $1.40 E-02$ & & & & \\
\hline 6 $\begin{array}{l}4957 \\
25-J A N-A 2 \\
15-A P R=B 2 \\
29-S E P-A 2\end{array}$ & & & . & $\begin{array}{l}1.30 E-01 \\
1.70 E=01 \\
1.50 E-01\end{array}$ & & & & \\
\hline $6 \begin{array}{l}5053 \\
15-A P K-B 2 \\
29-5 E P=82\end{array}$ & & & & $\begin{array}{l}1.30 E-02 \\
1.30 E=02\end{array}$ & & & & \\
\hline
\end{tabular}


CESIUN,

CüAalt,

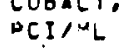
PCIML. DeIJAL PCI M L L -........
URANIUM,
MGIL

ลUT TENIUM

DCI/ML

CHRUMIUA

$M G / L$

FLUORIUE, LURIUE
MG/L 


\section{APPENDIX C}

\section{CHEMICAL AND SPECTROGRAPHIC ANALYSES}

FROM VARIOUS WELL SAMPLES 
TABLE C.1 Chemical and Spectrographic Analyses from Various Wells Sampled

\begin{tabular}{|c|c|c|c|c|c|c|c|}
\hline Constituents & Units & $399-8-4$ & 699-S3-E12 & $699-\$ 3-25$ & $699-\$ 12-3$ & 699-\$30-E15A & 699-1-18 \\
\hline Alk Tot Lab & $\mathrm{mg} / \mathrm{l}$ & 120 & 98 & 140 & 130 & 200 & 120 \\
\hline Aluminum & $\mu \mathrm{g} / \ell$ & $<50$ & $<50$ & 50 & $<50$ & $<50$ & 70 \\
\hline Antimony & $\mu \mathrm{g} / \ell$ & $<30$ & $<30$ & 30 & $<30$ & $<30$ & 30 \\
\hline Arsenic & $\mu \mathrm{g} / \ell$ & 8 & 7 & 6 & 6 & 3 & 6 \\
\hline Barium & $\mu \mathrm{g} / \ell$ & 50 & 30 & 70 & 30 & 50 & 50 \\
\hline Beryllium & $\mu \mathrm{g} / \mathrm{l}$ & $<1$ & $<1$ & $<1$ & $<1$ & $<1$ & $<1$ \\
\hline Bismuth & $\mu \mathrm{g} / \mathrm{l}$ & $<1000$ & $<1000$ & $<1000$ & $<1000$ & $<1000$ & $<1000$ \\
\hline Boron & $\mu \mathrm{g} / \mathrm{l}$ & 10 & 10 & 70 & 7 & 10 & 10 \\
\hline Bromide & $\mathrm{mg} / \mathrm{l}$ & 0.00 & 0.00 & 0.00 & 0.10 & 0.00 & $<0.01$ \\
\hline Cadmium & $\mu \mathrm{g} / \mathrm{l}$ & $<1$ & $<1$ & 7 & $<1$ & $<1$ & 1 \\
\hline Calcium & $\mathrm{mg} / \mathrm{l}$ & 35 & 24 & 62 & 42 & 60 & 46 \\
\hline Chloride & $\mathrm{mg} / \mathrm{l}$ & 8.6 & 4.6 & 22 & 17 & 4.1 & 9.9 \\
\hline Chromium & $\mu \mathrm{g} / \mathrm{l}$ & $<50$ & $<50$ & $<50$ & $<50$ & $<50$ & $<50$ \\
\hline Chromium Hex. & $\mu \mathrm{g} / \mathrm{l}$ & 2 & 2 & $<1$ & 2 & $<1$ & 7 \\
\hline Cobalt & $\mu \mathrm{g} / \mathrm{l}$ & $<5$ & $<5$ & 5 & $<5$ & $<5$ & 5 \\
\hline Color & PT-CO & $<1$ & $<1$ & $<1$ & $<1$ & $<1$ & $<1$ \\
\hline Copper & $\mu \mathrm{g} / \mathrm{l}$ & $<10$ & $<10$ & $<10$ & $<10$ & $<10$ & $<10$ \\
\hline Cyanide & $\mathrm{mg} / \mathrm{l}$ & $<0.01$ & $<0.01$ & $<0.01$ & $<0.01$ & $<0.01$ & $<0.01$ \\
\hline Fluoride & $\mathrm{mg} / \mathrm{l}$ & 0.3 & 0.3 & 0.5 & 0.4 & 0.2 & 0.4 \\
\hline Gallium & $\mu \mathrm{g} / \mathrm{l}$ & $<30$ & $<30$ & 70 & $<30$ & $<30$ & 100 \\
\hline Germanium & $\mu \mathrm{g} / \mathrm{l}$ & $<30$ & $<30$ & 70 & $<30$ & 30 & 70 \\
\hline Hardness & $\mathrm{mg} / \mathrm{l}$ & 120 & 93 & 220 & 140 & 200 & 160 \\
\hline Hardness Noncarb & $\mathrm{mg} / \mathrm{l}$ & 0 & 0 & 77 & 14 & 0 & 40 \\
\hline lodide & $\mathrm{mg} / \mathrm{l}$ & 0.00 & 0.00 & 0.02 & 0.00 & 0.00 & $<0.01$ \\
\hline Iron & $\mu \mathrm{g} / \mathrm{l}$ & $<5$ & 10 & 30 & 10 & 7 & 10 \\
\hline Lead & $\mu \mathrm{g} / \mathrm{l}$ & $<30$ & $<30$ & 30 & $<30$ & $<30$ & 50 \\
\hline Lithium & $\mu \mathrm{g} / \mathrm{l}$ & 10 & 7 & 30 & 7 & 10 & 10 \\
\hline Magnesium & $\mathrm{mg} / \mathrm{l}$ & 7.2 & 8.1 & 15 & 9.6 & 12 & 11 \\
\hline Manganese & $\mu \mathrm{g} / \mathrm{l}$ & 3 & 3 & 100 & 1 & 1 & 3 \\
\hline Molybdenum & $\mu \mathrm{g} / \mathrm{l}$ & $<10$ & 10 & 10 & $<10$ & $<10$ & 10 \\
\hline Nickel & $\mu \mathrm{g} / \mathrm{l}$ & $<50$ & $<50$ & $<50$ & $<50$ & $<50$ & $<50$ \\
\hline $\mathrm{Nitr} \mathrm{NO}_{2}$ as $\mathrm{N}$ & $\mathrm{mg} / \mathrm{l}$ & $<0.02$ & $<0.02$ & $<0.02$ & $<0.02$ & $<0.02$ & $<0.02$ \\
\hline $\mathrm{Nitr} \mathrm{NO}_{2}+\mathrm{NO}_{3}-\mathrm{N}$ & $\mathrm{mg} / \mathrm{l}$ & 2.5 & 3.2 & 0.28 & 1.9 & 4.5 & 5.9 \\
\hline Nitr $\mathrm{NH}_{4}$ as $\mathrm{N}$ & $\mathrm{mg} / \mathrm{l}$ & $<0.06$ & $<0.06$ & $<0.06$ & $<0.06$ & $<0.06$ & $<0.06$ \\
\hline Nitr $\mathrm{NH}_{4}$ as $\mathrm{NH}_{4}$ & $\mathrm{mg} / \mathrm{l}$ & 0.08 & 0.08 & 0.08 & 0.08 & 0.08 & 0.08 \\
\hline pH Field & & 7.6 & 8.3 & 7.8 & 7.9 & 7.5 & 8.2 \\
\hline pH Lab & & 8.0 & 8.4 & 8.2 & 8.3 & 7.9 & 8.4 \\
\hline Phosphorus as $\mathrm{P}$ & $\mathrm{mg} / \mathrm{l}$ & 0.03 & 0.01 & 0.03 & 0.04 & 0.03 & 0.03 \\
\hline Phosphorus & $\mathrm{mg} / \mathrm{l}$ & 0.03 & 0.01 & 0.03 & 0.03 & 0.02 & 0.03 \\
\hline Potassium & $\mathrm{mg} / \mathrm{l}$ & 4.6 & 4.7 & 7.7 & 5.8 & 6.0 & 6.6 \\
\hline Residue Calc Sum & $\mathrm{mg} / \mathrm{l}$ & 214 & 176 & 351 & 261 & 289 & 302 \\
\hline Residue at $180 \mathrm{C}$ & $\mathrm{mg} / \mathrm{l}$ & 228 & 187 & 356 & 254 & 306 & 293 \\
\hline Selenium & $\mu \mathrm{g} / \mathrm{l}$ & 1 & 3 & 6 & 2 & $<1$ & 4 \\
\hline Silica & $\mathrm{mg} / \mathrm{l}$ & 35 & 33 & 33 & 32 & 32 & 40 \\
\hline Silver & $\mu \mathrm{g} / \mathrm{l}$ & $<10$ & $<10$ & $<10$ & $<10$ & $<10$ & $<10$ \\
\hline SAR & & 0.7 & 0.6 & 0.8 & 0.9 & 0.6 & 0.8 \\
\hline Sodium & $\mathrm{mg} / \mathrm{l}$ & 17 & 13 & 26 & 24 & 17 & 23 \\
\hline Sodium Percent & & 23 & 22 & 20 & 26 & 15 & 23 \\
\hline Sp Conductance Fld & $\mu$ mhos & 310 & 255 & 540 & 394 & 450 & 422 \\
\hline Sp Conductance Lab & $\mu$ mhos & 319 & 256 & 535 & 395 & 455 & 422 \\
\hline Strontium & $\mu \mathrm{g} / \mathrm{l}$ & 300 & 100 & 300 & 100 & 300 & 300 \\
\hline Sulfate & $\mathrm{mg} / \mathrm{l}$ & 23 & 15 & 99 & 44 & 18 & 67 \\
\hline Tin & $\mu \mathrm{g} / \mathrm{l}$ & $<50$ & $<50$ & 100 & 50 & 70 & 300 \\
\hline Titanium & $\mu \mathrm{g} / \ell$ & $<5$ & $<5$ & 5 & $<5$ & $<5$ & 5 \\
\hline Turbidity & NTU & 2.0 & 1.6 & 1.2 & 3.5 & 0.5 & 1.4 \\
\hline Vanadium & $\mu \mathrm{g} / \ell$ & $<10$ & 10 & $<10$ & 10 & 10 & 10 \\
\hline Water Temp & ${ }^{\circ} \mathrm{C}$ & 16.6 & & 18.9 & 17.7 & 16.6 & 19.1 \\
\hline Zinc & $\mu \mathrm{g} / \mathrm{l}$ & 100 & $<9$ & 10 & $<9$ & $<9$ & 10 \\
\hline Zirconium & $\mu \mathrm{g} / \mathrm{l}$ & $<5$ & $<5$ & $<5$ & $<5$ & $<5$ & $<5$ \\
\hline Cesium-137 & $\mathrm{pCi} / \ell$ & $<1$ & $<1$ & $<1$ & $<1$ & $<1$ & $<1$ \\
\hline Cobalt-60 & $\mathrm{pCi} / \ell$ & $<1$ & $<1$ & $<1$ & $<1$ & $<1$ & 4 \\
\hline Gross Alpha, U-Nat & $\mu \mathrm{g} / \mathrm{l}$ & $<6.0$ & $<4.7$ & $<8.7$ & $<8.4$ & $<9.6$ & $<7.2$ \\
\hline Gross Beta, Cs-137 & $\mathrm{pCi} / \ell$ & 4.8 & 6.0 & 7.4 & 6.8 & 7.8 & 31 \\
\hline Gross Beta, Sr-90 & $\mathrm{pCi} / \ell$ & 4.6 & 5.7 & 7.1 & 6.5 & 7.4 & 30 \\
\hline Strontium-90 & $\mathrm{pCi} / \mathrm{l}$ & $<0.6$ & $<0.6$ & $<0.6$ & $<0.6$ & $<0.6$ & 4.3 \\
\hline Tritium & $\mathrm{pCi} / \ell$ & $<200$ & 1200 & $<200$ & $<200$ & 300 & 93000 \\
\hline
\end{tabular}


TABLE C.1. Contd

\begin{tabular}{|c|c|c|c|c|c|c|c|}
\hline Constituents & Units & $699-2-33$ & $699-10-E 12$ & $699-11-45 A$ & $699-15-15 B$ & $699-15-26$ & $699-17-5$ \\
\hline Alk Tot Lab & $\mathrm{mg} / \mathrm{l}$ & 130 & 160 & 120 & 120 & 130 & 100 \\
\hline Aluminum & $\mu \mathrm{g} / \mathrm{l}$ & 70 & $<50$ & $<50$ & $<50$ & $<50$ & $<50$ \\
\hline Antimony & $\mu \mathrm{g} / \mathrm{l}$ & $<30$ & $<30$ & $<30$ & $<30$ & $<30$ & $<30$ \\
\hline Arsenic & $\mu \mathrm{g} / \mathrm{l}$ & 6 & 9 & 3 & 8 & 9 & 3 \\
\hline Barium & $\mu \mathrm{g} / \mathrm{l}$ & 30 & 50 & 50 & 50 & 50 & 30 \\
\hline Beryllium & $\mu \mathrm{g} / \mathrm{l}$ & $<1$ & $<1$ & $<1$ & $<1$ & $<1$ & $<1$ \\
\hline Bismuth & $\mu \mathrm{g} / \ell$ & $<1000$ & $<1000$ & $<1000$ & $<1000$ & $<1000$ & $<1000$ \\
\hline Boron & $\mu \mathrm{g} / \mathrm{h}$ & 10 & 50 & 10 & 10 & 30 & 10 \\
\hline Bromide & $\mathrm{mg} / \mathrm{l}$ & 0.20 & 0.00 & 0.00 & $<0.01$ & $<0.01$ & 0.20 \\
\hline Cadmium & $\mu \mathrm{g} / \mathrm{l}$ & 1 & $<1$ & $<1$ & $<1$ & $<1$ & $<1$ \\
\hline Calcium & $\mathrm{mg} / \mathrm{l}$ & 42 & 45 & 33 & 54 & 48 & 70 \\
\hline Chloride & $\mathrm{mg} / \mathrm{l}$ & 5.8 & 8.2 & 5.2 & 6.7 & 9.9 & 19 \\
\hline Chromium & $\mu \mathrm{g} / \ell$ & $<50$ & $<50$ & $<50$ & $<50$ & $<50$ & $<50$ \\
\hline Chromium Hex. & $\mu \mathrm{g} / \mathrm{l}$ & $<1$ & 2 & $<1$ & $<1$ & 7 & $<1$ \\
\hline Cobalt & $\mu \mathrm{g} / \mathrm{l}$ & 5 & $<5$ & $<5$ & $<5$ & $<5$ & $<5$ \\
\hline Color & PT-CO & 5 & $<1$ & $<1$ & $<1$ & $<1$ & $<1$ \\
\hline Copper & $\mu \mathrm{g} / \ell$ & $<10$ & $<10$ & $<10$ & $<10$ & $<10$ & $<10$ \\
\hline Cyanide & $\mathrm{mg} / \mathrm{l}$ & $<0.01$ & $<0.01$ & $<0.01$ & $<0.01$ & $<0.01$ & $<0.01$ \\
\hline Fluoride & $\mathrm{mg} / \mathrm{l}$ & 0.3 & 0.3 & 0.3 & 0.3 & 0.4 & 0.2 \\
\hline Gallium & $\mu \mathrm{g} / \ell$ & 70 & $<30$ & $<30$ & $<30$ & $<30$ & $<30$ \\
\hline Germanium & $\mu \mathrm{g} / \mathrm{l}$ & 70 & $<30$ & 30 & $<30$ & 50 & $<30$ \\
\hline Hardness & $\mathrm{mg} / \mathrm{l}$ & 150 & 170 & 120 & 180 & 170 & \\
\hline Hardness Noncarb & $\mathrm{mg} / \mathrm{l}$ & 20 & 10 & 0 & 60 & 39 & \\
\hline lodide & $\mathrm{mg} / \mathrm{l}$ & 0.00 & 0.00 & 0.00 & $<0.01$ & $<0.01$ & $<0.01$ \\
\hline Iron & $\mu \mathrm{g} / \ell$ & 30 & 10 & 50 & 10 & 10 & 30 \\
\hline Lead & $\mu \mathrm{g} / \mathrm{l}$ & 30 & $<30$ & $<30$ & $<30$ & $<30$ & $<30$ \\
\hline Lithium & $\mu \mathrm{g} / \mathrm{l}$ & 10 & 7 & 7 & 10 & 10 & 7 \\
\hline Magnesium & $\mathrm{mg} / \mathrm{l}$ & 11 & 14 & 8.9 & 11 & 12 & 10 \\
\hline Manganese & $\mu \mathrm{g} / \ell$ & 10 & 1 & 100 & 7 & $<1$ & 1 \\
\hline Molybdenum & $\mu \mathrm{g} / \mathfrak{l}$ & 10 & 10 & $<10$ & $<10$ & 10 & 10 \\
\hline Nickel & $\mu \mathrm{g} / \mathrm{l}$ & $<50$ & $<50$ & $<50$ & $<50$ & $<50$ & $<50$ \\
\hline Nitr $\mathrm{NO}_{2}$ as $\mathrm{N}$ & $\mathrm{mg} / \mathrm{l}$ & $<0.02$ & $<0.02$ & 0.04 & $<0.02$ & $<0.02$ & $<0.02$ \\
\hline Nitr $\mathrm{NO}_{2}+\mathrm{NO}_{3}-\mathrm{N}$ & $\mathrm{mg} / \mathrm{l}$ & 0.57 & 3.8 & 0.96 & 4.7 & 5.8 & 1.4 \\
\hline Nitr $\mathrm{NH}_{4}$ as $\mathrm{N}$ & $\mathrm{mg} / \mathrm{l}$ & $<0.06$ & $<0.06$ & 1.0 & $<0.06$ & $<0.06$ & $<0.06$ \\
\hline Nitr $\mathrm{NH}_{4}$ as $\mathrm{NH}_{4}$ & $\mathrm{mg} / \mathrm{l}$ & 0.08 & 0.08 & 0.24 & 0.08 & 0.08 & 0.08 \\
\hline pH Field & & 7.7 & 7.8 & 7.7 & 7.9 & 7.9 & 7.9 \\
\hline pH Lab & & 8.2 & 8.2 & 8.0 & 8.2 & 8.2 & 8.2 \\
\hline Phosphorus as $\mathrm{P}$ & $\mathrm{mg} / \mathrm{l}$ & 0.02 & 0.01 & 0.01 & 0.02 & 0.02 & 0.01 \\
\hline Phosphorus & $\mathrm{mg} / \mathrm{l}$ & 0.02 & 0.01 & 0.02 & 0.02 & 0.04 & 0.02 \\
\hline Potassium & $\mathrm{mg} / \mathrm{t}$ & 4.4 & 5.5 & 4.6 & 6.4 & 6.3 & \\
\hline Residue Calc Sum & $\mathrm{mg} / \mathrm{l}$ & 228 & 277 & 183 & 308 & 299 & \\
\hline Residue at $180 \mathrm{C}$ & $\mathrm{mg} / \mathrm{l}$ & 224 & 263 & 179 & 305 & 297 & 339 \\
\hline Selenium & $\mu \mathrm{g} / \mathrm{l}$ & 4 & 3 & 1 & 11 & 4 & \\
\hline Silica & $\mathrm{mg} / \mathrm{l}$ & 36 & 43 & 25 & 33 & 36 & 50 \\
\hline Silver & $\mu \mathrm{g} / \mathrm{l}$ & $<10$ & $<10$ & $<10$ & $<10$ & $<10$ & $<10$ \\
\hline SAR & & 0.5 & 0.7 & 0.5 & 0.7 & 0.8 & \\
\hline Sodium & $\mathrm{mg} / \mathrm{l}$ & 12 & 19 & 11 & 20 & 23 & 10 \\
\hline Sodium Percent & & 14 & 19 & 16 & 19 & 22 & \\
\hline Sp Conductance Fld & $\mu \mathrm{mhos}$ & 335 & 408 & 290 & 445 & 445 & 505 \\
\hline Sp Conductance Lab & $\mu$ mhos & 310 & 403 & 293 & 446 & 447 & 494 \\
\hline Strontium & $\mu \mathrm{g} / \ell$ & 100 & 100 & 100 & 300 & 300 & 100 \\
\hline Sulfate & $\mathrm{mg} / \mathrm{l}$ & 36 & 29 & 18 & 84 & 60 & 65 \\
\hline Tin & $\mu \mathrm{g} / \mathrm{l}$ & 100 & 70 & 70 & $<50$ & 100 & 100 \\
\hline Titanium & $\mu \mathrm{g} / \mathrm{l}$ & $<5$ & $<5$ & $<5$ & $<5$ & $<5$ & $<5$ \\
\hline Turbidity & NTU & 4.5 & 2.8 & 1.2 & 14 & 0.8 & 7.4 \\
\hline Vanadium & $\mu \mathrm{g} / l$ & 10 & $<10$ & $<10$ & 10 & 10 & 30 \\
\hline Water Temp & ${ }^{\circ} \mathrm{C}$ & 19.3 & 19.3 & 19.3 & 19.4 & 18.8 & 19.0 \\
\hline Zinc & $\mu \mathrm{g} / \ell$ & $<9$ & 100 & 700 & 30 & $<9$ & 10 \\
\hline Zirconium & $\mu \mathrm{g} / \ell$ & 5 & $<5$ & $<5$ & $<5$ & $<5$ & $<5$ \\
\hline Cesium-137 & $\mathrm{pCi} / \mathrm{l}$ & $<1$ & $<1$ & $<1$ & $<1$ & $<1$ & $<1$ \\
\hline Cobalt -60 & $\mathrm{pCi} / \mathrm{l}$ & $<1$ & $<1$ & $<1$ & $<1$ & 6 & $<1$ \\
\hline Gross Alpha, U-Nat & $\mu \mathrm{g} / l$ & $<6.5$ & $<8.8$ & $<5.3$ & $<8.4$ & $<8.3$ & $<8.7$ \\
\hline Gross Beta, Cs-137 & $\mathrm{pCi} / \mathrm{l}$ & 4.8 & 6.4 & 4.3 & 10 & 23 & 6.0 \\
\hline Gross Beta, Sr-90 & $\mathrm{pCi} / \mathrm{l}$ & 4.6 & 6.1 & 4.2 & 9.8 & 22 & 5.7 \\
\hline Strontium-90 & $\mathrm{pCi} / \ell$ & $<0.6$ & $<0.6$ & $<0.6$ & $<0.6$ & 5.9 & $<0.6$ \\
\hline Tritium & $\mathrm{pCi} / \mathrm{l}$ & $<200$ & 6900 & $<200$ & $<200$ & 170000 & $<200$ \\
\hline
\end{tabular}


TABLE C. 1 Contd

\begin{tabular}{|c|c|c|c|c|c|c|c|}
\hline Constituents & Units & $699-32-70$ & $699-34-42$ & $699-42-2$ & $699-42-12$ & $699-46-5$ & 699-49-55 \\
\hline Alk Tot Lab & $\mathrm{mg} / \mathrm{l}$ & 120 & 110 & 120 & 120 & 120 & 40 \\
\hline Aluminum & $\mu \mathrm{g} / \mathrm{l}$ & $<50$ & 50 & 100 & $<50$ & $<50$ & 70 \\
\hline Antimony & $\mu \mathrm{g} / \mathrm{l}$ & $<30$ & 30 & $<30$ & $<30$ & $<30$ & $<30$ \\
\hline Arsenic & $\mu \mathrm{g} / \ell$ & 4 & 6 & 6 & 5 & 5 & 4 \\
\hline Barium & $\mu \mathrm{g} / \mathrm{l}$ & 70 & 30 & 50 & 50 & 30 & 30 \\
\hline Beryllium & $\mu \mathrm{g} / \mathrm{l}$ & $<1$ & $<1$ & $<1$ & $<1$ & $<1$ & $<1$ \\
\hline Bismuth & $\mu \mathrm{g} / \mathrm{l}$ & $<1000$ & $<1000$ & $<1000$ & $<1000$ & $<1000$ & $<1000$ \\
\hline Boron & $\mu \mathrm{g} / \mathrm{l}$ & 10 & 30 & 50 & 10 & 10 & 30 \\
\hline Bromide & $\mathrm{mg} / \mathrm{l}$ & $<0.01$ & $<0.01$ & $<0.01$ & $<0.01$ & $<0.01$ & 0.20 \\
\hline Cadmium & $\mu \mathrm{g} / \mathrm{l}$ & $<1$ & 1 & $<1$ & 1 & 1 & $<1$ \\
\hline Calcium & $\mathrm{mg} / \mathrm{l}$ & 34 & 32 & 41 & 43 & 43 & 67 \\
\hline Chloride & $\mathrm{mg} / \mathrm{l}$ & 12 & 11 & 11 & 12 & 12 & 22 \\
\hline Chromium & $\mu \mathrm{g} / \ell$ & $<50$ & $<50$ & $<50$ & $<50$ & $<50$ & $<50$ \\
\hline Chromium Hex. & $\mu \mathrm{g} / \mathrm{l}$ & 30 & $<1$ & 7 & 7 & 7 & $<1$ \\
\hline Cobalt & $\mu \mathrm{g} / \mathrm{l}$ & $<5$ & 5 & $<5$ & $<5$ & 5 & $<5$ \\
\hline Color & PT-CO & 5 & $<1$ & $<1$ & $<1$ & $<1$ & 25 \\
\hline Copper & $\mu \mathrm{g} / \ell$ & $<10$ & $<10$ & $<10$ & $<10$ & $<10$ & $<10$ \\
\hline Cyanide & $\mathrm{mg} / \mathrm{l}$ & $<0.01$ & $<0.01$ & 0.01 & $<0.01$ & $<0.01$ & $<0.01$ \\
\hline Fluoride & $\mathrm{mg} / \mathrm{l}$ & 0.4 & 0.6 & 0.3 & 0.4 & 0.4 & 0.4 \\
\hline Gallium & $\mu \mathrm{g} / \ell$ & $<30$ & 70 & $<30$ & $<30$ & 100 & 70 \\
\hline Germanium & $\mu \mathrm{g} / \mathrm{l}$ & 50 & 70 & 30 & 30 & 70 & 50 \\
\hline Hardness & $\mathrm{mg} / \mathrm{l}$ & 130 & 120 & 150 & 170 & 170 & 200 \\
\hline Hardness Noncarb & $\mathrm{mg} / \mathrm{l}$ & 10 & 11 & 32 & 49 & 45 & 160 \\
\hline lodide & $\mathrm{mg} / \mathrm{l}$ & $<0.01$ & $<0.01$ & $<0.01$ & $<0.01$ & $<0.01$ & $<0.01$ \\
\hline Iron & $\mu \mathrm{g} / \ell$ & 30 & 10 & 100 & 10 & 10 & 7 \\
\hline Lead & $\mu \mathrm{g} / \ell$ & $<30$ & 30 & $<30$ & $<30$ & 50 & 30 \\
\hline Lithium & $\mu \mathrm{g} / \mathrm{l}$ & 10 & 10 & 10 & 10 & 10 & 10 \\
\hline Magnesium & $\mathrm{mg} / \mathrm{l}$ & 11 & 9.9 & 12 & 15 & 14 & 8.3 \\
\hline Manganese & $\mu \mathrm{g} / \mathrm{l}$ & 1 & 1 & 1 & 7 & 1 & 10 \\
\hline Molybdenum & $\mu \mathrm{g} / \mathrm{l}$ & 10 & 10 & $<10$ & $<10$ & 30 & 30 \\
\hline Nickel & $\mu \mathrm{g} / \ell$ & $<50$ & $<50$ & $<50$ & $<50$ & $<50$ & $<50$ \\
\hline Nitr $\mathrm{NO}_{2}$ as $\mathrm{N}$ & $\mathrm{mg} / \mathrm{l}$ & $<0.02$ & $<0.02$ & $<0.02$ & $<0.02$ & $<0.02$ & 0.04 \\
\hline Nitr $\mathrm{NO}_{2}+\mathrm{NO}_{3}-\mathrm{N}$ & $\mathrm{mg} / \mathrm{l}$ & 3.8 & 5.9 & 7.1 & 8.3 & 6.7 & 0.92 \\
\hline Nitr $\mathrm{NH}_{4}$ as $\mathrm{N}$ & $\mathrm{mg} / \mathrm{l}$ & $<0.06$ & $<0.06$ & $<0.06$ & $<0.06$ & $<0.06$ & 0.07 \\
\hline Nitr $\mathrm{NH}_{4}$ as $\mathrm{NH}_{4}$ & $\mathrm{mg} / \mathrm{l}$ & 0.08 & 0.08 & 0.08 & 0.08 & 0.08 & 0.09 \\
\hline pH Field & & 7.7 & 7.9 & 7.9 & 7.9 & 7.8 & 8.8 \\
\hline pH Lab & & 8.1 & 8.2 & 8.2 & 8.2 & 8.2 & 8.8 \\
\hline Phosphorus as $\mathrm{P}$ & $\mathrm{mg} / \mathrm{l}$ & 0.05 & 0.03 & 0.02 & 0.02 & 0.02 & 0.02 \\
\hline Phosphorus & $\mathrm{mg} / \mathrm{l}$ & 0.04 & 0.03 & 0.01 & 0.01 & 0.02 & 0.02 \\
\hline Potassium & $\mathrm{mg} / \mathrm{l}$ & 4.1 & 6.1 & 5.3 & 5.4 & 4.7 & 13 \\
\hline Residue Calc Sum & $\mathrm{mg} / \mathrm{l}$ & 236 & 268 & 269 & 311 & 290 & 438 \\
\hline Residue at $180 \mathrm{C}$ & $\mathrm{mg} / \mathrm{l}$ & 230 & 257 & 281 & 301 & 277 & 437 \\
\hline Selenium & $\mu \mathrm{g} / \mathrm{l}$ & 2 & 2 & 2 & 3 & 3 & 9 \\
\hline Silica & $\mathrm{mg} / \mathrm{l}$ & 43 & 43 & 39 & 40 & 40 & 24 \\
\hline Silver & $\mu \mathrm{g} / \mathrm{l}$ & $<10$ & $<10$ & $<10$ & $<10$ & $<10$ & $<10$ \\
\hline SAR & & 0.7 & 1.2 & 0.7 & 0.9 & 0.8 & 1.4 \\
\hline Sodium & $\mathrm{mg} / \mathrm{l}$ & 18 & 28 & 19 & 26 & 22 & 45 \\
\hline Sodium Percent & & 22 & 32 & 21 & 24 & 22 & 31 \\
\hline Sp Conductance Fld & $\mu$ mhos & 345 & 375 & 395 & 450 & 410 & 632 \\
\hline Sp Conductance Lab & $\mu$ mhos & 342 & 387 & 393 & 447 & 402 & 637 \\
\hline Strontium & $\mu \mathrm{g} / \mathrm{l}$ & 300 & 100 & 1000 & 300 & 300 & 300 \\
\hline Sulfate & $\mathrm{mg} / \mathrm{l}$ & 25 & 45 & 38 & 60 & 52 & 230 \\
\hline Tin & $\mu \mathrm{g} / \ell$ & 100 & 100 & 50 & 70 & 300 & 100 \\
\hline Titanium & $\mu \mathrm{g} / \mathrm{l}$ & $<5$ & $<5$ & 10 & $<5$ & $<5$ & $<5$ \\
\hline Turbidity & NTU & 8.0 & 0.8 & 1.0 & 1.9 & 1.0 & 16 \\
\hline Vanadium & $\mu \mathrm{g} / \ell$ & 10 & 30 & $<10$ & 10 & 30 & $<10$ \\
\hline Water Temp & ${ }^{\circ} \mathrm{C}$ & 21.2 & 20.3 & 17.8 & 17.6 & 17.7 & 18.3 \\
\hline Zinc & $\mu \mathrm{g} / \ell$ & 10 & $<9$ & $<9$ & 10 & $<9$ & $<9$ \\
\hline Zirconium & $\mu \mathrm{g} / \ell$ & $<5$ & 5 & $<5$ & $<5$ & 5 & $<5$ \\
\hline Cesium-137 & $\mathrm{pCi} / \ell$ & $<1$ & $<1$ & $<1$ & $<1$ & $<1$ & $<1$ \\
\hline Cobalt -60 & $\mathrm{pCi} / \mathrm{l}$ & $<1$ & 7 & 9 & 10 & 8 & $<1$ \\
\hline Gross Alpha, U-Nat & $\mu \mathrm{g} / \mathrm{l}$ & $<6.5$ & $<7.6$ & $<8.9$ & $<8.6$ & $<7.1$ & $<9.5$ \\
\hline Gross Beta, Cs-137 & $\mathrm{pCi} / \mathrm{l}$ & 7.7 & 36 & 25 & 30 & 29 & 10 \\
\hline Gross Beta, Sr-90 & $\mathrm{pCi} / \mathrm{l}$ & 7.4 & 35 & 24 & 29 & $<27$ & 9.7 \\
\hline Strontium-90 & $\mathrm{pCi} / \mathrm{l}$ & $<0.6$ & 6.5 & 8.6 & 9.7 & 8.1 & $<0.6$ \\
\hline Tritium & $\mathrm{pCi} / \mathrm{l}$ & 270000 & 180000 & 200000 & 330000 & 220000 & $<200$ \\
\hline
\end{tabular}


TABLE C. 1 Contd

Constituents

Alk Tot Lab

Aluminum

Antimony

Arsenic

Barium

Beryllium

Bismuth

Boron

Bromide

Cadmium

Calcium

Chloride

Chromium

Chromium Hex.

Cobalt

Color

Copper

Cyanide

Fluoride

Gallium

Germanium

Hardness

Hardness Noncarb

lodide

Iron

Lead

Lithium

Magnesium

Manganese

Molybdenum

Nickel

Nitr $\mathrm{NO}_{2}$ as $\mathrm{N}$

Nitr $\mathrm{NO}_{2}+\mathrm{NO}_{3}-\mathrm{N}$

Nitr $\mathrm{NH}_{4}$ as $\mathrm{N}$

Nitr $\mathrm{NH}_{4}$ as $\mathrm{NH}_{4}$

$\mathrm{pH}$ Field

$\mathrm{pH}$ Lab

Phosphorus as $\mathrm{P}$

Phosphorus

Potassium

Residue Calc Sum

Residue at $180 \mathrm{C}$

Selenium

Silica

Silver

SAR

Sodium

Sodium Percent

Sp Conductance Fld

Sp Conductance Lab Strontium

Sulfate

Tin

Titanium

Turbidity

Vanadium

Water Temp

Zinc

Zirconium

Cesium-137

Cobalt -60

Gross Alpha, U-Nat

Gross Beta, Cs-137

Gross Beta, Sr-90

Strontium-90

Tritium
Units

699-64-27

$\mathrm{mg} / \mathrm{l}$

$\mu \mathrm{g} / \ell$

$\mu \mathrm{g} / \mathrm{l}$

$\mu \mathrm{g} / \ell$

$\mu \mathrm{g} / \mathrm{l}$

$\mu \mathrm{g} / \mathrm{l}$

$\mu \mathrm{g} / 1$

$\mu \mathrm{g} / \ell$

$\mathrm{mg} / \mathrm{l}$

$\mu \mathrm{g} / \mathrm{l}$

$\mathrm{mg} / \mathrm{l}$

$\mathrm{mg} / \mathrm{l}$

$\mu \mathrm{g} / \mathrm{l}$

$\mu \mathrm{g} / \ell$

$\mu \mathrm{g} / \mathrm{l}$

PT-CO

$\mu \mathrm{g} / \mathrm{l}$

$\mathrm{mg} / \mathrm{l}$

$\mathrm{mg} / \mathrm{l}$

$\mu \mathrm{g} / \ell$

$\mu \mathrm{g} / \mathrm{l}$

$\mathrm{mg} / \mathrm{l}$

$\mathrm{mg} / \mathrm{l}$

$\mathrm{mg} / \mathrm{l}$

$\mu \mathrm{g} / \ell$

$\mu \mathrm{g} / \ell$

$\mu \mathrm{g} / \mathrm{l}$

$\mathrm{mg} / \mathrm{l}$

$\mu \mathrm{g} / \ell$

$\mu \mathrm{g} / \ell$

$\mu \mathrm{g} /$

$\mathrm{mg} / \mathrm{l}$

$\mathrm{mg} / \mathrm{l}$

$\mathrm{mg} / \mathrm{l}$

$\mathrm{mg} / \mathrm{l}$

$\mathrm{mg} / \mathrm{l}$

$\mathrm{mg} / \mathrm{l}$

$\mathrm{mg} / \mathrm{l}$

$\mathrm{mg} / \mathrm{l}$

$\mathrm{mg} / \mathrm{l}$

$\mu \mathrm{g} / \mathrm{l}$

$\mathrm{mg} / \mathrm{l}$

$\mu \mathrm{g} / \mathrm{\ell}$

$\mathrm{mg} / \mathrm{l}$

$\mu$ mhos

$\mu$ mhos

$\mu \mathrm{g} / \mathrm{l}$

$\mathrm{mg} / \mathrm{l}$

$\mu \mathrm{g} / \ell$

$\mu \mathrm{g} / \mathrm{l}$

NTU

$\mu \mathrm{g} / \mathrm{l}$

${ }^{\circ} \mathrm{C}$

$\mu \mathrm{g} / \mathrm{l}$

$\mu \mathrm{g} / \mathrm{l}$

pCi/l

$\mathrm{pCi} / \mathrm{l}$

$\mu \mathrm{g} / \ell$

pCi/l

$\mathrm{pCi} / \mathrm{l}$

pCi/ $\ell$

$\mathrm{pCi} / \mathrm{l}$
699-81-58

96
$<50$
$<30$
2
10
$<1$
$<1000$
$<5$
0.00
$<1$
29
1.3
$<50$
2
$<5$
$<1$
$<10$
$<0.01$

0.1

$<30$

$<30$

100

0.00

5

$<30$

5

7.4

3

$<50$

$<0.02$

0.38

$<0.06$

$<0.01$

0.01

2.6

135

129

1

16
$<10$

0.2

4.0

8

214

213

15

$<5$

5.3

$<10$

16.6

$<9$
$<5$

$<1$

$<1$

$<3.9$

3.1

3.0

$<0.6$

$<200$ 


\section{DISTRIBUTION}

No. of

Copies

OFFSITE

Kent Ashbaker

Water Quality Division

Oregon State Dept. of Environmental Quality

P.O. Box 1760

Portland, OR 97207

S. R. Arlt

City of Richland

Water and Sewer Department

P.O. Box 190

Richland, WA 99352

H. L. Cahn

Benton-Franklin District Health Department

Richland, WA 99352

D. E. Clark

Exxon Nuclear

Horn Rapids Road

Richland, WA 99352

E. Cowan

Environmental Protection Agency

Region X

1200 6th Avenue/MS-533

Seattle, WA 98101

Norman Dion

U.S. Geological Survey

1201 Pacific Avenue, Suite 600

Tacoma, WA 98402

DOE Technical Information Center

S. R. Elliott

DOE Office of Safety and Health

P.O. Box 14100

L. A. Forsythe/DP-226

DOE Office of Military Application

Washington, DC 20545

12 506 McKenzie

Las Vegas, NV 89114

No. of

Copies

OFFSITE

Fred Hahn

Washington State Department of Ecology MS PV-11

Olympia, WA 98504

Russell Jim, Councilman

Attn: Erline Reber

Yakima Indian Nation

P.O. Box 151

Toppenish, WA 98948

W. A. Kiel

Washington Public Power Supply System 3000 George Washington Way

Richland, WA 99352

N. P. Kirner

Washington State Department of Social and Health Services

MS LF-13

Olympia, WA 98504

J. B. Martin

Regional Administrator

NRC Region V

Suite 210

1450 Marie Lane

Walnut Creek, CA 94596-5368

R. R. Mooney

DSHS-Division of Health,

Radiation Control Section

1409 Smith Tower, B17-9

Seattle, WA 98104

D. W. Moos

Washington State Department of Ecology

MS PV-11

Olympia, WA 98504

G G. Outterson

Section 543

Battelle Memorial Institute

505 King Avenue

Columbus, $\mathrm{OH} 43201$

Washington State Department of Ecology

MS PV-11

Olympia, WA 98504

M. O. Fretwell

Water Resources Division

U.S. Geological Survey

345 Middlefield Road, MS-66

Menlo Park, CA 94025
R. D. Paris

Oregon State Health Division

1400 S.W. Fifth Avenue

Portland, OR 97201

D. E. Patterson/EP-32

DOE Office of Operational Safety

Washington, DC 20545 
J. K. Price

Washington Public Power Supply System

P.O. Box 968 MS 540

Richland, WA 99352

J. B. Robertson

U.S. Geological Survey

MS-410

Reston, VA 22092

\section{T. Strong}

Washington State Department of Social and Health Services

MS LF-13

Olympia, WA 98504

G. Toombs

Oregon State Health Division

P.O. Box 231

Portland, OR 97207

Washington State Department of Ecology

Library PV-11

Olympia, WA 98504

C. G. Welty/EP-323

DOE Office of Operational and

Environmental Safety

Washington, DC 20545

\section{ONSITE}

DOE Richland Operations Office

R. E. Austin (5)

O. J. Elgert (2)

D. R. Elle (10)

R. E. Gerton

H. E. Ransom

A. J. Rizzo

J. L. Rhoades

F. R. Standerfer

M. W. Tiernan

Hanford Environmental Health Foundation

L. J. Maas

R. J. Gilmore

\section{Rockwell Hanford Operations}

K. A. Gasper

M. J. Graham (4)

H. A. Haerer

A. G. Law

M. M. McCarthy

W. H. Price

B. J. Saueressig

J. S. Wilbur

RHO File
9

\author{
United Nuclear Corporation \\ P. A. Carlson \\ L. P. Diediker \\ J. J. Dorian \\ E. M. Greager \\ D. L. Renberger \\ A. P. Vinther \\ E. A. Weakley \\ W. G. Westover \\ UNC File
}

3

68

Westinghouse Hanford Company

R. O. Budd

R. B. Hall

D. O. Hess

Pacific Northwest Laboratory

G. E. Backman

S. C. Blair

P. J. Blumer

P. E. Bramson

F. P. Brauer

J. M. Carlile

C. S. Cline

J. P. Corley

D. W. Damschen

R. L. Dirkes

D. W. Dragnich

P. A. Eddy (20)

P. J. Gutknecht

E. L. Hilty

C. T. Kincaid

L. J. Kirby

H. V. Larson

T. L. Liikala

W. D. McCormack

V. L. McGhan

M. A. McKinney

G. M. Petrie

L. S. Prater (5)

K. R. Price

M. R. Quarders

J. R. Raymond

J. T. Rieger (5)

D. J. Sommer

M. J. Sula

P. D. Thorne

C. M. Unruh

L. L. Wendell

D. A. Zimmerman

Technical Information (5)

P. E. Bramson-Historical File

Publishing Coordination (2) 